OPEN-FILE REPORT 90-554

EVALUATION OF SELECTED METHODS FOR DETERMINING - ŚTREAMFLOW DURING PERIODS OF ICE EFFECT

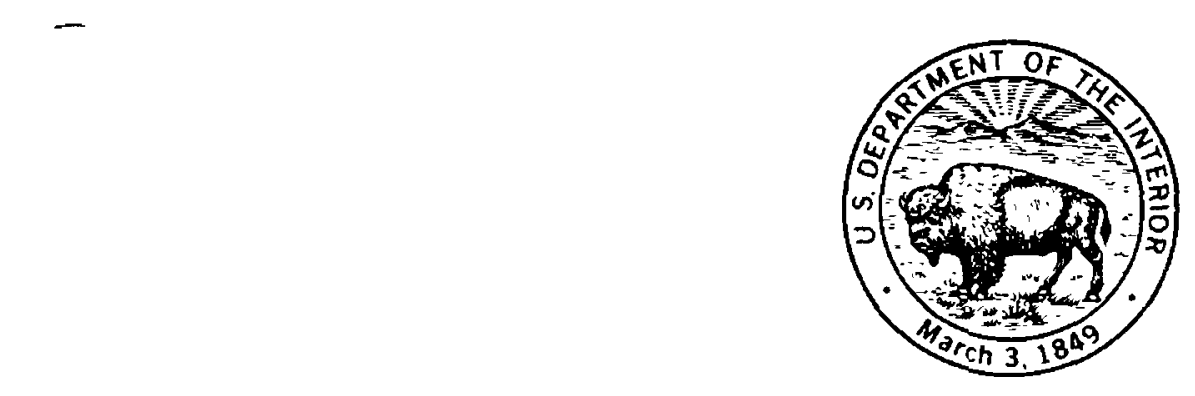

Prepared by

UNITED STATES DEPARTMENT OF THE INTERIOR GEOLOGICAL SURVEY 



\section{EVALUATION OF SELECTED METHODS FOR DETERMINING STREAMFLOW DURING PERIODS OF ICE EFFECT}

By

N.B. Melcher and J.F. Walker

U.S. GEOLOGICAL SURVEY

Open-File Report 90-554 


\section{U.S. DEPARTMENT OF THE INTERIOR}

MANUEL LUJAN, JR., Secretary

\section{U.S. GEOLOGICAL SURVEY}

Dallas L. Peck, Director

For additional information write to:

District Chief

U.S. Geological Survey

6417 Normandy Lane

Madison, WI 53719
Copies of this report can

be purchased from:

U.S. Geological Survey

Books and Open-File Reports Section

Federal Center, Box 25425

Building 810

Denver, CO 80225 


\section{CONTENTS}

Abstract

Introduction

Methods of study.

Survey

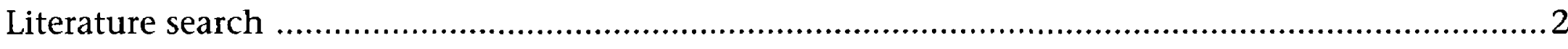

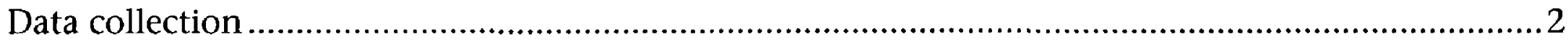

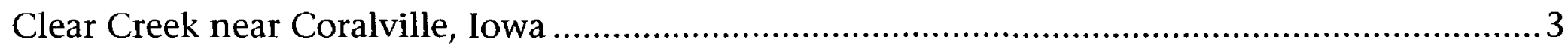

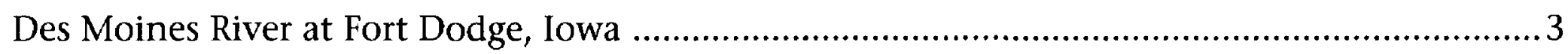

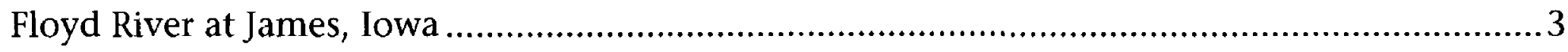

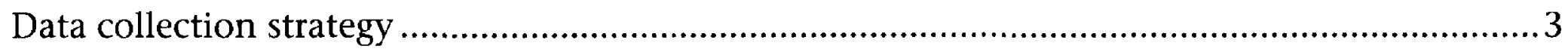

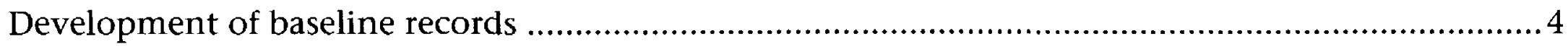

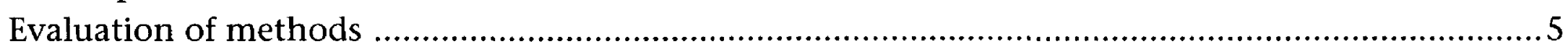

Description of methods for determining streamflow during periods of ice effect .................................5

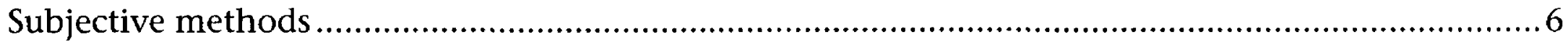

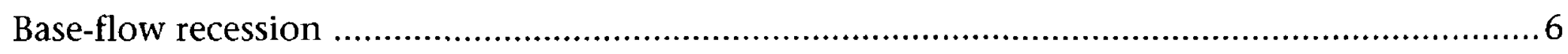

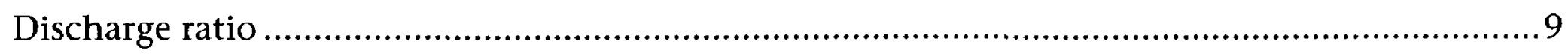

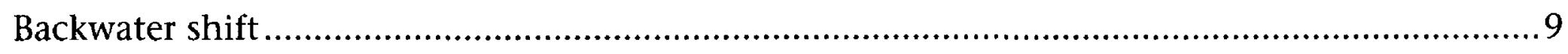

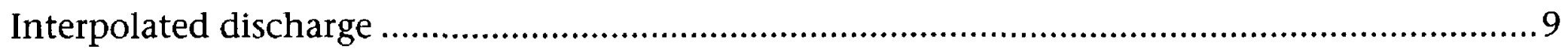

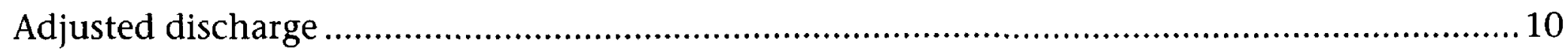

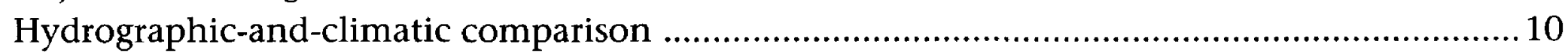

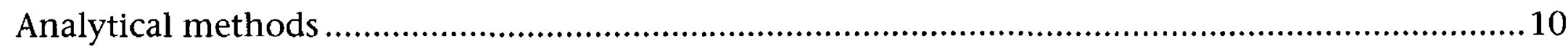

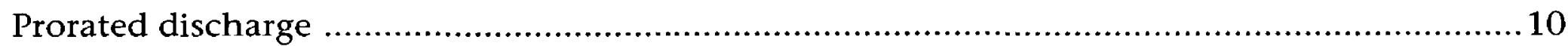

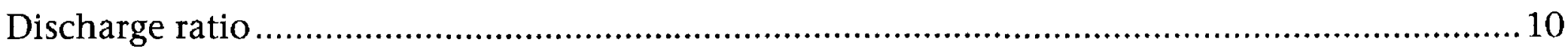

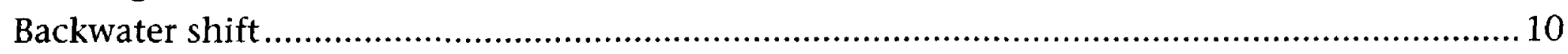

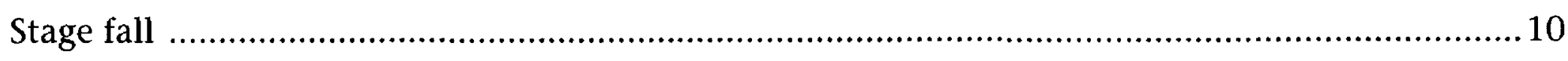

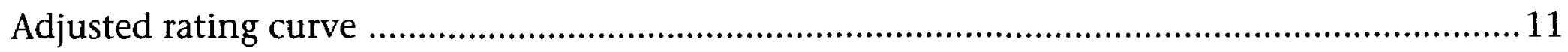

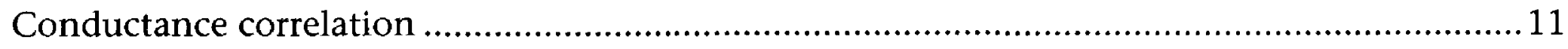

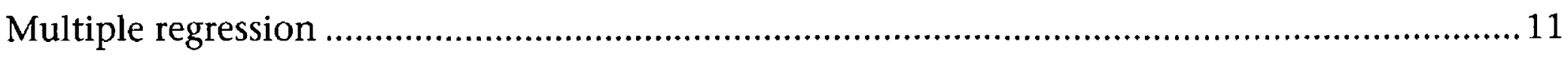

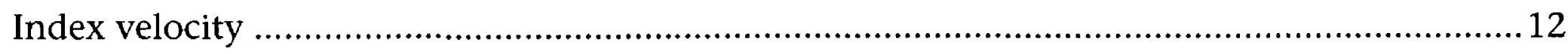

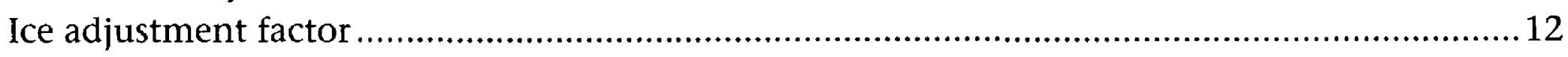

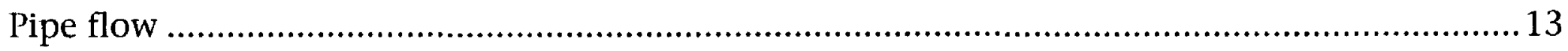

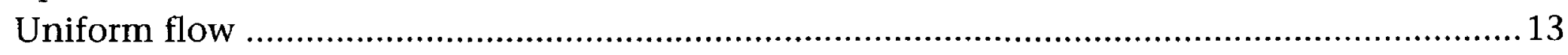

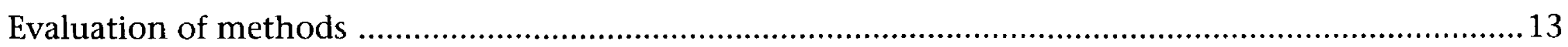

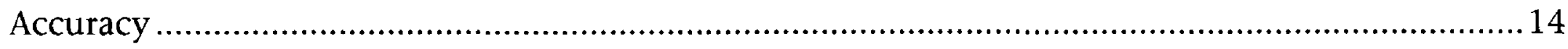

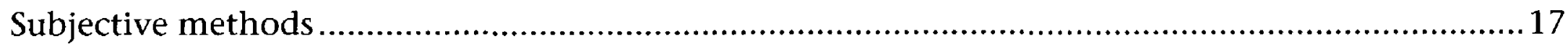

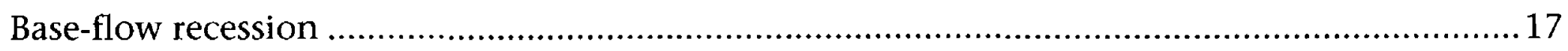

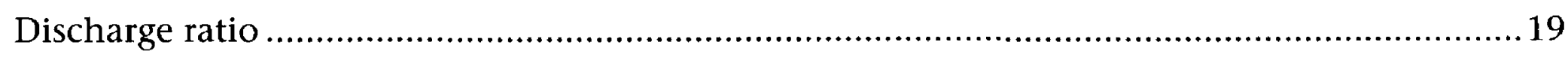

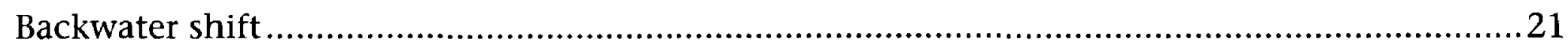

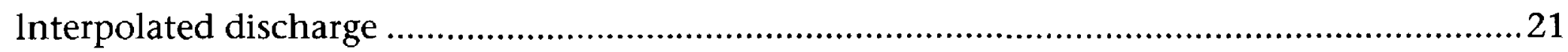

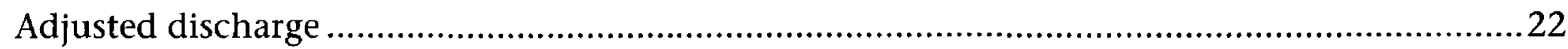

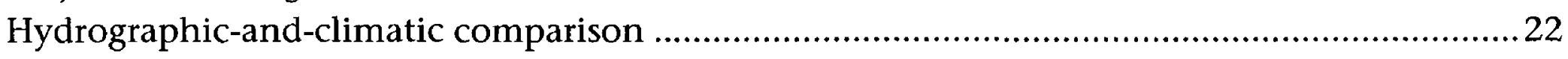

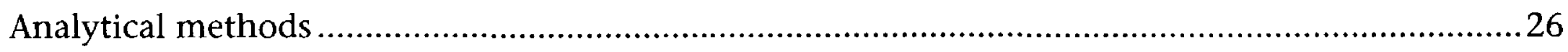

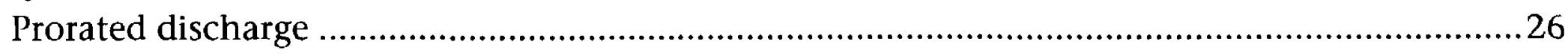

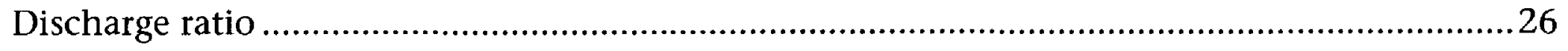

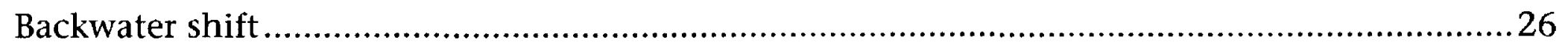


Analytical methods (Continued)

Stage fall 29

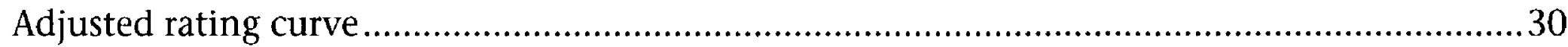

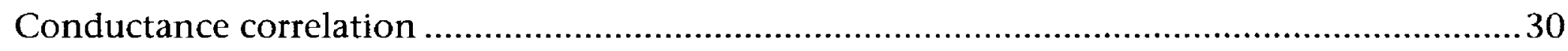

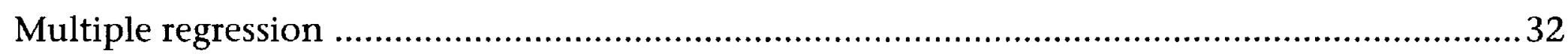

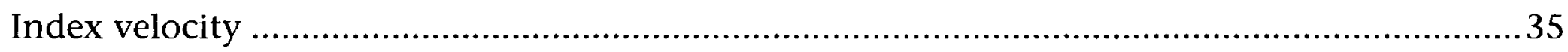

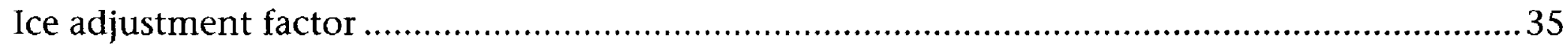

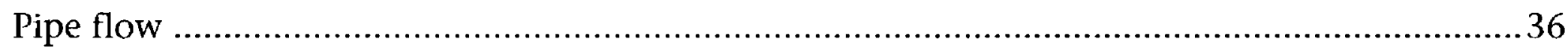

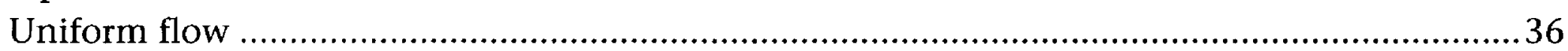

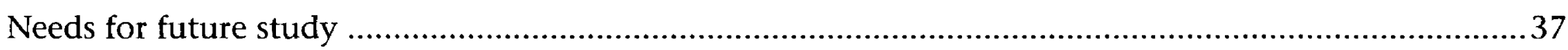

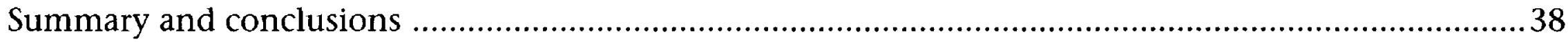

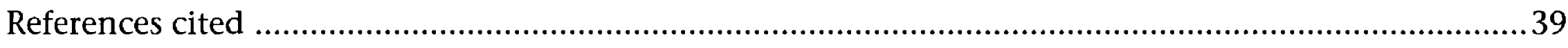

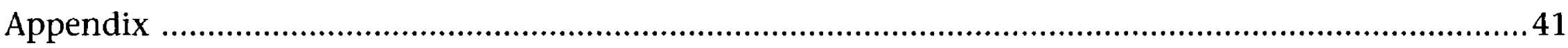

\section{ILLUSTRATIONS}

Figure 1. Map showing location of test streamflow-gaging stations,

correlated streamflow-gaging stations, and climatological

stations in Iowa.....

2. Graph showing baseline streamflow record, indicated open-water

discharges, measured discharges, and nearby climatological data for:

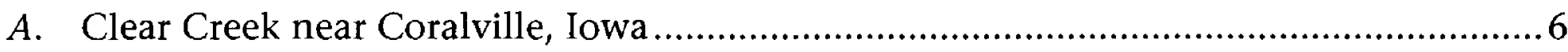

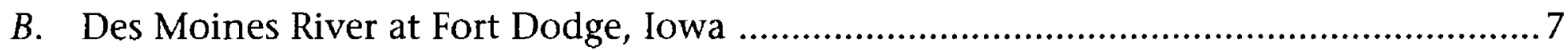

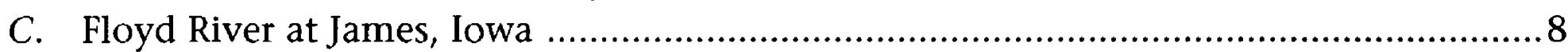

3. Graph showing summary of relative errors for selected methods applied to:

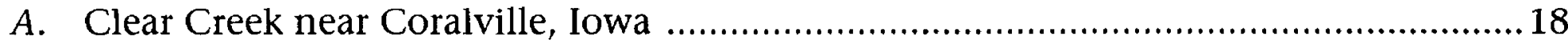

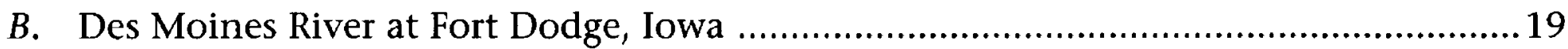

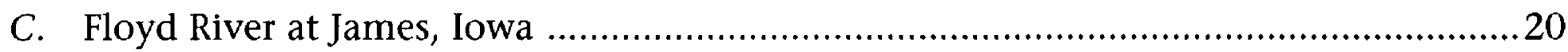

4. Hydrographs for Clear Creek near Coralville showing baseline daily mean discharge and daily mean discharge estimated by:

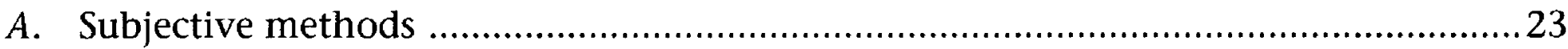

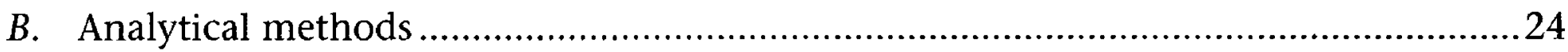

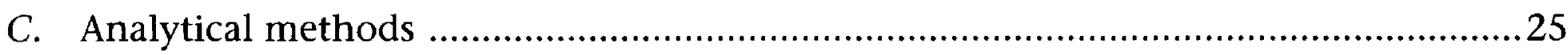

5. Hydrographs for the Des Moines River at Fort Dodge showing baseline daily mean discharge and daily mean discharge estimated by:
A. Subjective methods
B. Analytical methods
C. Analytical methods

6. Hydrographs for the Floyd River at James showing baseline daily mean discharge and daily mean discharge estimated by:
A. Subjective methods
$B$. Analytical methods
C. Analytical methods 


\section{TABLES}

Table 1. Statewide monthly temperature, precipitation, and snowfall in Iowa for the

1987-88 winter period, and averages for the 1951-80 period 3

2. Description of streamflow-gaging stations and periods of ice effect monitored during the $1987-88$ winter

3. Regression equations used for the conductance correlation method ............................. 12

4. Regression equations used for the multiple regression method .....................................13

5. Average discharge for the ice-affected period determined by each method, and the percent error compared to the average baseline discharge.

6. Statistical summary of the error between estimated daily discharge and baseline daily discharge

7. Percentage distribution of the relative error for the daily discharge values for selected ranges in error

8. Significance levels for the difference between estimated discharge for each method and the baseline discharge 34

9. Results from the Kruskal-Wallis one-way analysis of variance comparing the record compilations by three hydrographers to the baseline record for each method 


\section{CONVERSION TABLE}

For readers who prefer metric (International System) units, inch-pound units in this report may be converted by the following factors.

Multiply inch-pound unit

inch (in.)

foot $(\mathrm{ft})$

mile (mi)

square mile $\left(\mathrm{mi}^{2}\right)$

cubic foot per second $\left(\mathrm{ft}^{3} / \mathrm{s}\right)$

degree Fahrenheit $\left({ }^{\circ} \mathrm{F}\right)$
By

25.4

0.3048

1.609

2.590

0.02832

$0.555-\left({ }^{\circ} \mathrm{F}-32\right)$
To obtain metric unit

millimeter $(\mathrm{mm})$

meter (m)

kilometer $(\mathrm{km})$

square kilometer $\left(\mathrm{km}^{2}\right)$

cubic meter per second $\left(\mathrm{m}^{3} / \mathrm{s}\right)$

degree Celsius $\left({ }^{\circ} \mathrm{C}\right)$ 


\title{
EVALUATION OF SELECTED METHODS FOR DETERMINING STREAMFLOW DURING PERIODS OF ICE EFFECT
}

\author{
By \\ N.B. Melcher and J.F. Walker
}

\begin{abstract}
Seventeen methods for estimating ice-affected streamflow are evaluated for potential use for the U.S. Geological Survey streamflow-gaging station network. The methods evaluated were identified by written responses from U.S. Geological Survey field offices and by a comprehensive literature search. The methods selected and techniques used for applying the methods are described in the report.

The methods are evaluated by comparing estimated results to data collected at three streamflow-gaging stations in Iowa during the winter of 1987-88. Discharge measurements were obtained at 1- to 5-day intervals during the ice-affected periods at the three stations to define an accurate baseline record. Discharge records were compiled for each method based on data available assuming a 6-week field schedule.

The methods are classified into two general categories, subjective and analytical, depending on whether individual judgement is necessary for method application. On the basis of results of the evaluation for the three Iowa stations, two of the subjective methods (discharge ratio and hydrographic-and-climatic comparison) were more accurate than the other subjective methods, and approximately as accurate as the best analytical method. Three of the analytical methods (index velocity, adjusted rating curve, and uniform flow) could potentially be used for streamflow-gaging stations where the need for accurate ice-affected discharge estimates justifies the expense of collecting additional field data. One analytical method (ice adjustment factor) may be appropriate for use for stations with extremely stable stage-discharge ratings and measuring sections. Further research is needed to refine the analyti-
\end{abstract}

cal methods. The discharge ratio and multiple regression methods produce estimates of streamflow for varying ice conditions using information obtained from the existing U.S. Geological Survey streamflow-gaging network.

\section{INTRODUCTION}

The U.S. Geological Survey operates continuous streamflow-gaging stations at more than 6,500 locations in the United States. Discharge at streamflowgaging stations is normally computed using a defined relation between stream stage and stream discharge. This relation is referred to as a stage-discharge rating. The stage-discharge rating at more than one-half of the stations is affected by backwater from ice formation during part of the winter (see Appendix table A2). The most commonly used method of estimating streamflow during periods of ice cover depends on the hydrographer's judgement and is not readily adapted to automated data processing. This method evolved more than 50 years ago and does not use automated data processing techniques nor does it fully incorporate advances in the understanding of ice hydraulics. Because the method depends on individual judgement, the accuracy of ice-affected streamflow estimates had not previously been defined. The inability to automate the process of estimating ice-affected streamflow records increases streamflow gaging-station operation costs. An evaluation of proposed and other existing methods for determining streamflow during periods of ice effect was conducted by the U.S. Geological Survey.

This report presents the findings of a study that investigated methods for determining streamflow dur- 
ing periods of ice effect. Selected methods were evaluated in terms of accuracy, cost, technical soundness, ice conditions, application to computers, and feasibility for use in the U.S. Geological Survey streamflow-gaging network. The accuracy of the selected methods was estimated by using data collected at three representative streamflow-gaging stations in lowa. The findings of this study apply to streamflow-gaging stations with characteristics which are comparable to the three sites investigated.

\section{METHODS OF STUDY}

Identification of existing and proposed methods for determining streamflow during ice-affected periods was accomplished by a written survey of U.S. Geological Survey field offices and by a comprehensive literature search. The objectives of the survey were to assess the frequency and types of ice effect at streamflow-gaging stations and to identify all methods presently used by the U.S. Geological Survey to compute ice-affected streamflow record. A literature search was conducted to identify methods used for computation of ice-affected streamflow record by other countries or methods proposed by the scientific community. The identified methods were then evaluated for three selected sites in Iowa.

\section{SURVEY}

A written survey of all U.S. Geological Survey field offices was completed in June of 1987 . This survey evaluated the frequency and types of ice effects at streamflow-gagingstations throughout the United States, identified methods used to compute ice-affected streamflow record, and assessed the time and cost of computing ice-affected streamflow record. The survey results indicated that ice effects occurred at streamflow-gaging stations in 44 of 50 States. Some ice effect occurred at 3,734 of 6,616 streamflow-gaging stations. Of the total ice-affected days reported, 68 percent were affected by complete surface ice cover, 17 percent by shore ice, 11 percent by anchor ice, and 4 percent by frazil ice. The computation of ice-affected streamflow record required extra computation time and increased the cost of compiling streamflow records.

Almost all offices use the hydrographic-and-climatic-comparison method to compile ice-affected streamflow record. The most frequently used data are winter discharge measurements, hydrographic comparison, air temperature and winter precipitation records, and recorded stage. The only method reported in the survey that uses a systematically applied procedure for computing ice-affected streamflow is the dischargeratio method. Twelve districts reported at least occasional use of this method and these districts indicate it provides reasonable results for some streamflow-gaging stations.

Several districts reported using backwater shifts as a method for verifying ice-affected streamflow record particularly during freeze-up or break-up periods. Recession curves or coefficients, stream conductivity, and index stations are considered to be important information and are used in conjunction with the hydrographic-and-climatic-comparison method by several districts. No systematic use of these methods was reported. A copy of the original survey and selected results are included in the appendix.

\section{LITERATURE SEARCH}

Methods used by other countries or proposed by the scientific community were identified through literature searches or by communications with subject authorities. Searches by subject matter were conducted at several comprehensive scientific libraries. Scientific journals and symposium proceedings related to ice studies were examined for ideas or proposed methods for determining streamflow during ice-affected periods. Personal contacts were made with subject authorities or scientific organizations which have experienced staff and recognized expertise in ice-related investigations.

Several articles proposed methods and described their use. Modifications of an author's suggested procedures were at times necessary during this study to make the method compatible with the U.S. Geological Survey streamflow-gaging network, or to adapt the method to equipment or technology presently available.

Ideas for other methods were found in articles that described or investigated other ice-related phenomenon. The specific procedures for method application were not always described in these articles; therefore procedures for method application were developed during this study.

\section{DATA COLLECTION}

The various ice conditions that typically occur in lowa are representative of ice conditions that occur throughout much of the United States. Streams in the mid-Iatitude regions of the United States tend to have intermittent ice-affected periods during the winter. Warming trends during the winter months cause stream runoff to occur and frequently cause the ice cover to clear from the channel. Streams in the northern States typically have only one extended period of ice cover.

Streams in southern lowa are affected by ice from about mid-December through late February, and warming trends occur throughout the winter. These warming trends are often long enough to cause increases in stream runoff and may cause the channel ice to clear from rivers and streams. Streams in the northern part of 
the State are ice affected from early December through mid-March. Warming trends long enough to cause significant runoff are unusual during the winter months and, typically, ice cover on streams in northern lowa remains stable throughout the winter.

Field data for evaluating the selected methods were collected during the winter of 1987-88. The meteorological conditions in Iowa during the 1987-88 winter were near normal (table 1).

Data for evaluating the selected methods were collected at three streamflow-gaging stations in Iowa (fig. 1). These stations were selected to represent a range of hydrologic and hydraulic conditions. These conditions include drainage area, channel width, mean depth, control conditions, and gage equipment. A description of the three streams and the ice periods monitored are summarized in table 2 . Complete surface ice cover was the cause of backwater during most of the study period for the three test stations. Anchor ice, floating or submerged frazil ice, and shore ice were observed during some periods

\section{Clear Creek near Coralville, Iowa}

This station is located on a small tributary of the Iowa River in east-central Iowa. The Clear Creek basin is in the Southern Iowa Drift Plain (Prior, 1976). The area has mature topography with an integrated drainage of weathered glacial till overlain by a moderate to thick loess cover. The region is humid; average precipitation is $34.6 \mathrm{in} / \mathrm{yr}$ (inches per year) and average snowfall is $28.6 \mathrm{in} / \mathrm{yr}$. The mean annual temperature is 50.2 ${ }^{\circ} \mathrm{F}$ and the mean January temperature is $19.8^{\circ} \mathrm{F}$ (E. May, Iowa State Climatologist, written commun., 1988). The basin drainage area is $98.1 \mathrm{mi}^{2}$ (square miles); during winter the channel width is about $45 \mathrm{ft}$ (feet) and the mean effective depth is about $0.8 \mathrm{ft}$. The streambed is composed of sand and silt and the station has a shifting Iow-water control. River stage is recorded using a stilling well with a digital paper-tape primary recorder and is supplemented by an analog recorder.

\section{Des Moines River at Fort Dodge, Iowa}

This station is located on the main stem of the Des Moines River in north-central Iowa. The Des Moines River basin is in the Des Moines Lobe. This area is overlain with recent glacial drift and is poorly drained. The region is humid; average precipitation is $32.3 \mathrm{in} / \mathrm{yr}$ and average snowfall is $39.5 \mathrm{in} / \mathrm{yr}$. The mean annual temperature is $47.5^{\circ} \mathrm{F}$ and the mean January temperature is $15.8^{\circ} \mathrm{F}$ (E. May, Iowa State Climatologist, written commun., 1988). The basin drainage area is $4,190 \mathrm{mi}^{2}$; during winter the channel width is about $320 \mathrm{ft}$ and the mean depth is about $1.5 \mathrm{ft}$. The streambed is composed of gravel and cobbles and the station control is stable. River stage is recorded using a stilling well with a digital paper-tape recorder.

\section{Floyd River at James, lowa}

This station is located on a tributary to the Missouri River in northwestern lowa. The Floyd River basin is in the Northwest Iowa Plains. This area has mature topography with an integrated drainage and is overlain with moderate to thick loess cover. The region is sub-humid; average precipitation is $25.4 \mathrm{in} / \mathrm{yr}$ and average snowfall is $31.6 \mathrm{in} / \mathrm{yr}$. The mean annual temperature is $48.4{ }^{\circ} \mathrm{F}$ and the mean January temperature is $16.2^{\circ} \mathrm{F}$ (E. May, Iowa State Climatologist, written commun., 1988). The basin drainage area is $882 \mathrm{mi}^{2}$; during winter the channel width is about $110 \mathrm{ft}$ and the mean depth is about $0.7 \mathrm{ft}$. The streambed is composed of silt and fine sand and the station has a moderately shifting control. River stage is recorded using a mercury manometer with a digital paper-tape primary recorder and is supplemented by an analog recorder.

\section{Data Collection Strategy}

Discharge measurements were made at the three streamflow-gaging stations at 1- to 5-day intervals during periods of ice effect using standard ice-measurement techniques (Buchanan and Somers, 1969). Vertical

Table 1.-Statewide monthly temperature, precipitation, and snowfall in Iowa for the 1987-88 winter period, and averages for the 1951-80 period

\begin{tabular}{lcccccc}
\hline & \multicolumn{2}{c}{$\begin{array}{c}\text { Temperature } \\
\left({ }^{\circ} \mathrm{F}\right)\end{array}$} & \multicolumn{2}{c}{$\begin{array}{c}\text { Precipitation } \\
\text { (inches) }\end{array}$} & \multicolumn{2}{c}{$\begin{array}{c}\text { Snowfall } \\
\text { (inches) }\end{array}$} \\
Month & $\begin{array}{c}1987-88 \\
\text { winter }\end{array}$ & $\begin{array}{c}1951-80 \\
\text { average }\end{array}$ & $\begin{array}{c}1987-88 \\
\text { winter }\end{array}$ & $\begin{array}{c}\text { 1951-80 } \\
\text { average }\end{array}$ & $\begin{array}{c}\text { 1987-88 } \\
\text { winter }\end{array}$ & $\begin{array}{c}1951-80 \\
\text { average }\end{array}$ \\
\hline December & 32.9 & 28.6 & 2.61 & 1.85 & 12.4 & 9.5 \\
January & 15.5 & 16.4 & .60 & .76 & 2.6 & 5.0 \\
February & 15.1 & 19.3 & .02 & .52 & 8.9 & 7.8 \\
\hline
\end{tabular}

Source: Iowa Department of Agriculture and Land Stewardship, Weather Summaries, Monthly

${ }^{1}$ Average monthly snowfall from E. May, Iowa State Climatologist, written. commun. (1988) 
velocity profiles also were made at three locations across the measurement cross-sections by measuring point velocity at nine equal depth percentages $(10,20, \ldots, 80$, 90 percent). A description of the appearance of the ice was recorded during each discharge measurement, and a representative block of ice was cut from the ice cover and the underside was photographed and described in the measurement notes.

Once-daily measurements of specific conductance were obtained at the gaging stations. Records of point velocity were maintained for the streamflow-gaging stations on the Des Moines River at Ft. Dodge and Clear Creek near Coralville. Point velocity record was not collected at the Floyd River at James site because only two sets of velocity monitoring equipment were available. Auxiliary gages were operated $3.0 \mathrm{mi}$ (miles) downstream from the Floyd River at James and $1.9 \mathrm{mi}$ downstream from Clear Creek at Coralville. Gage height was obtained at the auxiliary gages by once-daily readings from a wire-weight gage or by measuring the distance from the stream water surface to a reference point. Because section control exists for all normal winter flows at the Des Moines River at Fort Dodge, auxiliary gage height data was not collected.

\section{DEVELOPMENT OF BASELINE RECORDS}

A baseline daily streamflow record was developed for each station to evaluate the selected methods. The

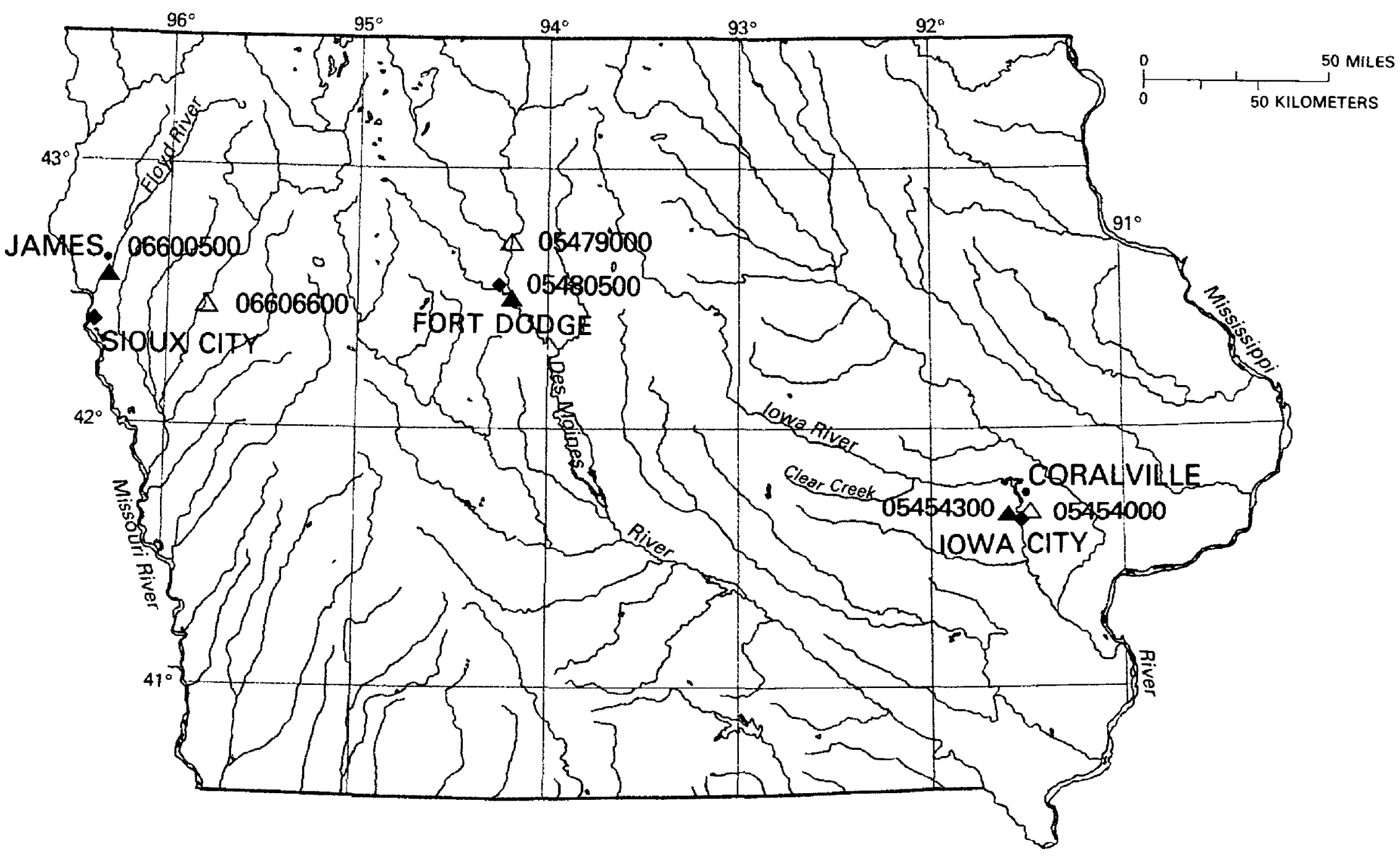

EXPLANATION

$\begin{array}{cc}\triangle 05454300 & \begin{array}{c}\text { Test streamflow-gaging station } \\ \text { and number }\end{array} \\ \triangle 05454000 & \begin{array}{c}\text { Correlated streamflow-gaging } \\ \text { station and number }\end{array}\end{array}$

- IOWA CITY Climatological station and name

Figure 1. Location of test streamflow-gaging stations, correlated streamflow-gaging stations, and climatological stations in Iowa. 
baseline record was constructed by hydrographers experienced in making ice-affected streamflow estimates and familiar with the streamflow-gaging stations and local topography. All discharge measurements and ancillary information were used to develop daily streamflow records. The frequency of the data collection significantly reduced the interpretation required to construct the ice-affected streamflow records. The daily streamflow records were reviewed by several personnel experienced in compiling and reviewing ice-affected streamflow records, and were accepted as baseline conditions. The discharge record is referred to as a baseline record because, for statistical analysis purposes, it is considered to be a correct discharge and is the basis for comparing and analyzing the selected methods. Because of the small amount of interpretation needed to compile the baseline record the discharge values are not absolute. The completed records, the discharge measurements, the indicated open-water discharge hydrographs, and climatic data are shown in figure 2 . The indicated open-water discharges are the discharges computed for periods of ice effect using the stagedischarge rating without adjustments for ice effect. Because of the increased friction and reduced flow area resulting from ice cover, the indicated open-water discharge is usually greater than the actual discharge.

\section{EVALUATION OF METHODS}

Each selected method was evaluated for accuracy and other criteria related to the operation of the U.S. Geological Survey streamflow-gaging network. The accuracy evaluation included several measures of error determined by comparing each method to the baseline streamflow record. A subset of the measurements used to compile the baseline record was used in the evaluation to simulate the usual schedule of field data collection. The evaluation also included criteria which are not readily quantified, yet are important considerations for evaluation of the selected methods, such as cost, technical soundness, ice conditions, application to computers, and feasibility of application to the U.S. Geological Survey streamflow-gaging network.

\section{DESCRIPTION OF METHODS FOR DETERMINING STREAMFLOW DURING PERIODS OF ICE EFFECT}

In this section a brief description of each method is presented. Procedures for some methods were established specifically for this study, and these procedures are described in the following sections. Each discussion concludes with a description of the data required to develop and apply the method.

The selected methods are classified into two general categories depending on whether individual judgement is necessary for method application. These two categories are referred to as subjective and analytical methods. Discharge estimates using analytical methods generally are consistent and reproducible because the results are obtained by a systematic computation. Subjective method results may vary because the methods are dependent on individual judgement. Given the same set of field data and procedures, two hydrographers working independently should compile the same

Table 2. -Description of streamflow-gaging stations and periods of ice effect monitored during the 1987-88 winter

[mi ${ }^{2}$, square miles]

\begin{tabular}{llcccc}
\hline Station & Name & $\begin{array}{c}\text { Drainage } \\
\text { area } \\
\left(\mathbf{m i}^{2}\right)\end{array}$ & $\begin{array}{c}\text { Number of ice } \\
\text { measurements }\end{array}$ & $\begin{array}{c}\text { Number of } \\
\text { ice affected days }\end{array}$ & $\begin{array}{c}\text { Period(s) of } \\
\text { ice effect }\end{array}$ \\
\hline 05454300 & $\begin{array}{l}\text { Clear Creek near } \\
\text { Coralville, Iowa }\end{array}$ & 98.1 & 33 & 66 & $\begin{array}{l}\text { Dec. 15-20 } \\
\text { Dec. 31-Jan. 19 }\end{array}$ \\
05480500 & $\begin{array}{l}\text { Des Moines River at } \\
\text { Fort Dodge, Iowa }\end{array}$ & 4,190 & 21 & 67 & $\begin{array}{l}\text { Jan. 22-Jan. 31 } \\
\text { Feb. 2-Feb. 29 }\end{array}$ \\
& $\begin{array}{l}\text { Dec. 3-Dec. 4 } 4 \\
\text { Dec. 15-Dec. 18 } \\
\text { Dec. 29-Feb. 29 }\end{array}$ \\
& $\begin{array}{l}\text { Floyd River at } \\
\text { James, lowa }\end{array}$ & 882 & 39 & 79 & Dec. 15-Mar. 2 \\
\hline
\end{tabular}


results using an analytical method, but the two results may vary using a subjective method. Some analytical methods are only intended for use in one particular ice condition and may not be applicable for all ice conditions encountered at a streamflow-gaging station. Subjective methods generally can be used for all ice conditions. The first six methods are subjective; the remaining eleven methods are analytical. The discharge-ratio and backwater-shift methods were evaluated using subjective and analytical solutions.

\section{SUBJECTIVE METHODS}

\section{Base-flow Recession}

The base-flow recession method uses the normal recession rate of the nongrowing season to estimate
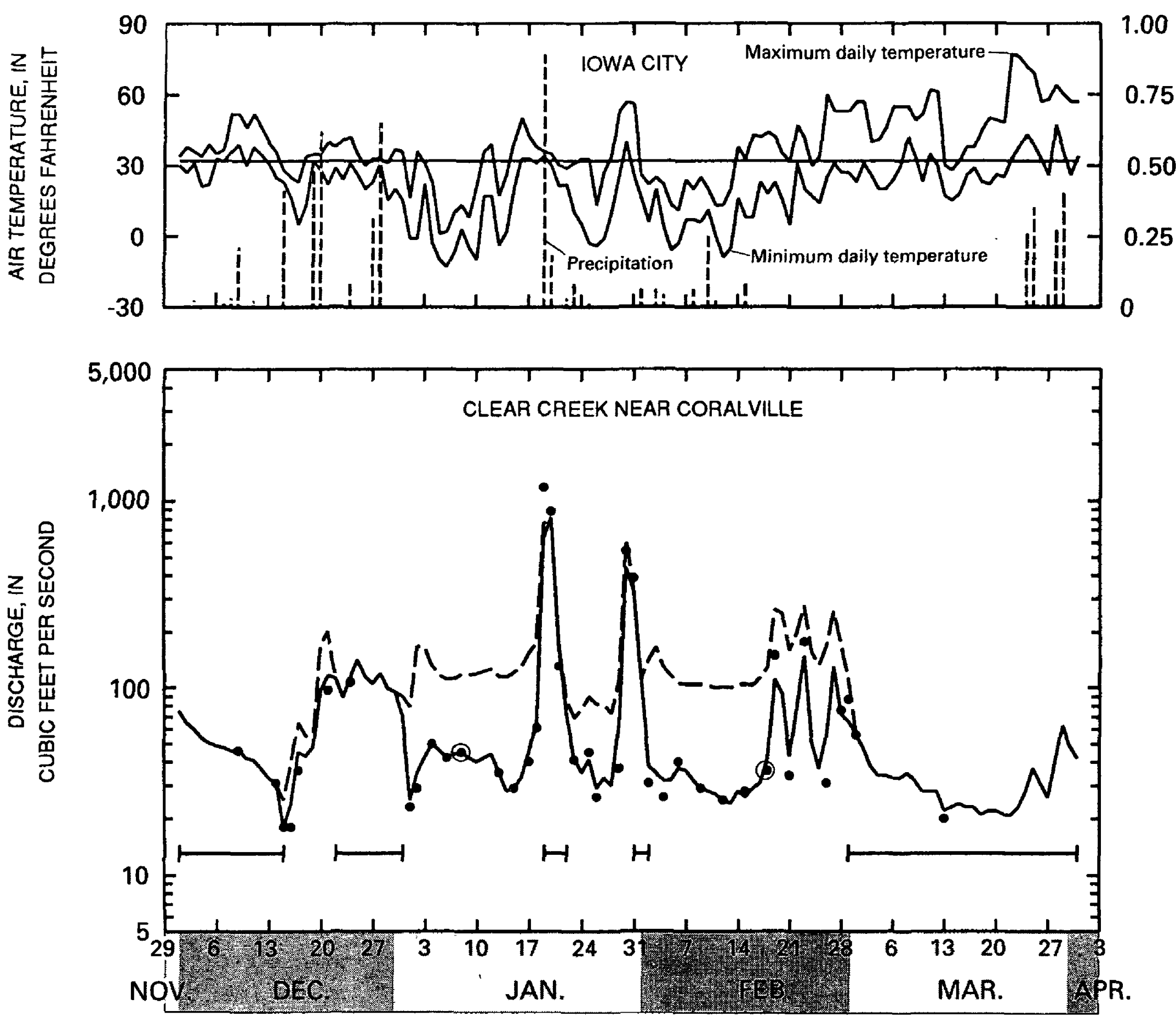

1987-88 WINTER PERIOD

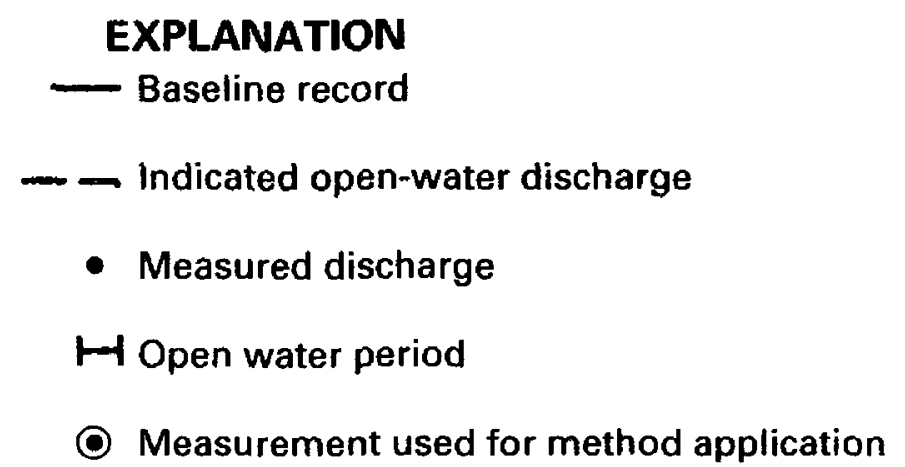

Figure 2A. Baseline streamflow record, indicated open-water discharges, measured discharges, and nearby climatological data for Clear Creek near Coralville, Iowa. 
streamflow during ice-affected periods (Rosenberg and Pentland, 1983). The recession for a station is determined by an equation or by a graph. The equation which commonly is used to estimate recession discharge is:

$$
Q_{t}=Q_{0} C^{\left(t-t_{0}\right)}
$$

where

$Q_{t}$ is the discharge at time $t$,

$Q_{Q}$ is the discharge at time $t_{o}$, and

$C$ is the recession constant.

The recession constant is defined by historical data. Discharge is computed by multiplying the discharge prior to the ice-affected period $\left(Q_{0}\right)$ by the appropriate factor determined by eq. (1).
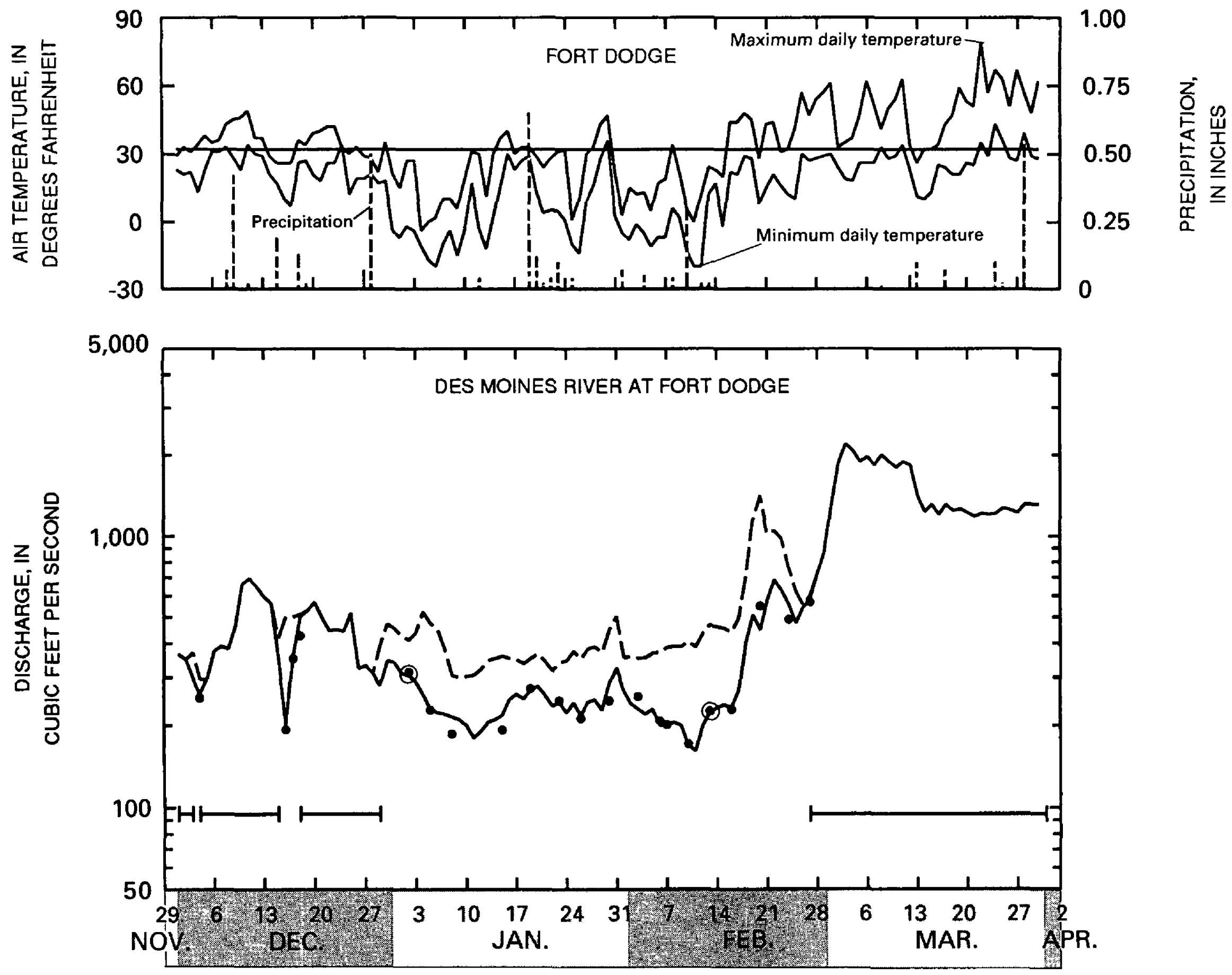

1987-88 WINTER PERIOD

EXPLANATION

- Baseline record

- - Indicated open-water discharge

- Measured discharge

H Open water period

- Measurement used for method application

Figure $2 B$. Baseline streamflow record, indicated open-water discharges, measured discharges, and nearby climatological data for the Des Moines River at Fort Dodge, Iowa. 
Ice-affected streamflow can be estimated using a graphical solution to the base-flow recession method. An appropriate engineering curve is selected and aligned with the general recession indicated by a hydrograph of daily mean discharge values. This recession curve is drawn on the hydrograph and estimated daily discharge values are defined by this curve. The shape of the recession in prior years and winter discharge measurements during ice-affected periods are also considered in drawing the recession curve. The equation and graphical solutions to the recession curve method normally will produce similar results.

For this study, the base-flow recession method was applied using the graphical solution. The discharge for
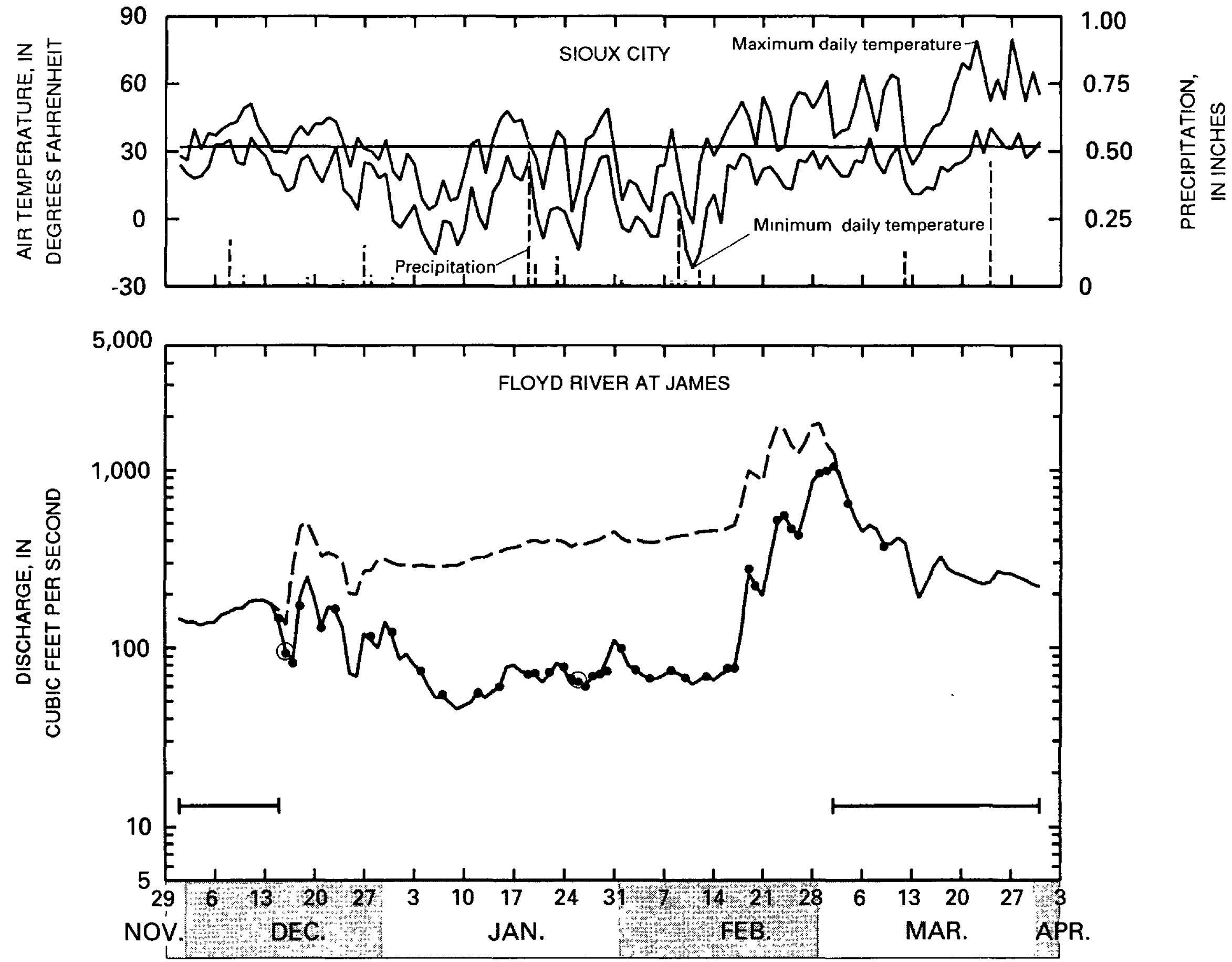

1987-88 WINTER PERIOD

\footnotetext{
EXPLANATION

- Baseline record

- Indicated open-water discharge

- Measured discharge

$\mapsto$ Open water period

- Measurement used for method application
}

Figure 2C. Baseline streamflow record, indicated open-water discharges, measured discharges, and nearby climatological data for the Floyd River at James, Iowa. 
periods without ice effect, the indicated open-water discharges during periods of ice effect, and the maximum and minimum daily air temperatures were plotted on semilogarithmic paper. The recession curve was then drawn based on the general shape of the nongrowing season hydrograph recession. The hydrographs for the previous 2 water years were also considered in defining the recession curve. The recession curve accounted for available discharge measurements by adjusting the discharge for a few days before and after the discharge measurement or by adjusting the slope of the curve for the entire ice period depending on the hydrographer's interpretation of the cause for the discrepancy between indicated open-water discharge and the measured discharge. The curve was extended until the end of the ice period and merged with the open-water hydrograph.

\section{Discharge Ratio}

The discharge ratio method uses the ratio of measured discharge to rated discharge to adjust the indicated open-water discharge during ice-affected periods (Rosenberg and Pentland, 1983; Rantz and others, 1982). The ratio (K-factor) for each measurement is calculated by the following equation:

$$
K=\frac{Q_{m}}{Q_{r}}
$$

where

$Q_{m}$ is the measured discharge, and

$Q_{T}$ is the rated discharge for the indicated gage height.

The computed K-factor for each discharge measurement is plotted on semilogarithmic paper. The plotted points are connected by modified interpolation considering the effects of changing meteorological conditions. The K-factor is merged with a value of 1.0 on the day prior to and after each ice period. The indicated openwater discharges for each ice-affected day are then adjusted by the K-factor obtained from the K-factor line.

This method can be applied using a graphical solution. Discharge measurements, the open-water periods, and indicated open-water discharges are plotted on semilogarithmic hydrograph paper. The vertical distance on the hydrograph between each ice-affected discharge measurement and the corresponding indicated open-water discharge is measured. This distance is then measured vertically from a selected reference line on the $\log$ scale corresponding to a value of 1.0 , and the displaced point indicated by this measurement is marked on the plot. A factor line is then drawn through the displaced point by the same method used for the analytical solution. The indicated open-water discharges are adjusted by measuring the distance from the reference line to the factor line and subtracting this distance from the indicated open-water discharge line. If the factor line and the K-factor line are the same, the equation and the graphical solutions will produce identical results.

For this study discharge was computed using the Kfactor equation. The K-factor was computed using the ratio of the measured discharge and the indicated openwater discharge for the mean gage height during the measurement. A modified interpolated K-factor line was drawn considering meteorological records and used to adjust the indicated open-water discharges.

\section{Backwater Shift}

The backwater shift method uses the backwater computed from the open-water stage-discharge rating to estimate discharge during ice-affected periods (Rosenberg and Pentland, 1983; Rantz and others, 1982). The backwater for each discharge measurement made during ice-affected conditions is computed by subtracting the gage height indicated by the stage-discharge rating from the recorded gage height. The computed backwater shifts are plotted on hydrograph paper. A backwater curve for the ice-affected period is drawn by modified interpolation of the plotted backwater shifts, considering the effects of changing meteorological conditions on stream backwater. The backwater shift for each ice-affected day is determined from the backwater curve and is subtracted from the recorded gage height to compute the effective gage height. The discharge for the effective gage height is obtained from the stagedischarge rating and plotted on semilogarithmic hydrograph paper.

For this study the backwater shifts were computed and plotted on rectangular-coordinate paper. The backwater shift curve was drawn considering meteorological records and was merged with the shifts that were used to compute the open-water periods before and after the ice-affected period. The estimated discharge values were obtained from the stage-discharge rating and plotted on semilogarithmic hydrograph paper. The values were confirmed by comparison with theindicated openwater discharges, and the backwater curve was adjusted as necessary.

\section{Interpolated Discharge}

The interpolated discharge method (Rosenberg and Pentland, 1983) uses a modified interpolation of daily discharge for periods between discharge measurements to estimate discharge during ice-affected periods. Discharge measurements during ice-affected periods and discharges computed during open-water periods are plotted on semilogarithmic hydrograph paper. This method does not use the indicated open-water dis- 
charges. Discharges for ice-affected periods are estimated and plotted on this hydrograph by interpolating between discharge measurements. This interpolation is modified considering hydrographic comparison with nearby streamflow-gaging stations and meteorological records.

For this study, ice-affected record was estimated using discharge measurements during ice-affected periods, discharge data computed for open-water periods, and the hydrograph record for one nearby hydrologically similar streamflow-gaging station.

\section{Adjusted Discharge}

The adjusted discharge method uses modified interpolation between discharge measurements to estimate daily mean discharge during ice-affected periods (Rosenberg and Pentland, 1983). Discharge measurements during ice-affected periods, the indicated openwater discharges, discharges computed during open-water periods, and local meteorological records are plotted on semilogarithmic hydrograph paper. This method does not use hydrographic comparison. Discharges for ice-affected periods between discharge measurements are estimated and plotted on this hydrograph by modified interpolation considering the other data plotted on the hydrograph.

For this study, the ice-affected record was estimated using discharge measurements during ice-affected periods, discharge data computed for open-water periods, and local meteorological records.

\section{Hydrographic-and-Climatic Comparison}

The hydrographic-and-climatic-comparison method generally is used by the U.S. Geological Survey to estimate discharge during ice-affected periods (Rantz and others, 1982). Discharge measurements, the indicated open-water discharges, meteorological informátion, and notes or observations on ice conditions are plotted on semilogarithmic hydrograph paper. Values of daily mean discharge are estimated and plotted on this hydrograph on the basis of discharges for periods without ice effect, the normal trend of the winter hydrograph recession, daily discharge estimates for other nearby streamflow-gaging stations, and local climatological records.

For this study, discharge was estimated using a hydrograph of open-water and indicated open-water discharges, discharge measurements, local meteorological records, and a hydrograph for one nearby hydrologically similar streamflow-gaging station.

\section{ANALYTICAL METHODS}

\section{Prorated Discharge}

The prorated discharge method uses a linear interpolation of daily discharge for periods between dis- charge measurements to estimate discharge during iceaffected periods. Discharge measurements during iceaffected periods and discharges computed during open-water periods are plotted on semilogarithmic hydrograph paper or are written in tabular form. Discharges for ice-affected periods are estimated by straightline interpolation on the hydrograph or computed by linear interpolation between discharge measurements. The ice-affected days preceding and subsequent to the first and last ice-affected measurements were estimated by linear interpolation between the discharge computed for the last and first open-water day and the first and last discharge measurement.

For this study, ice-affected record was estimated using direct interpolation in tabular form

\section{Discharge Ratio}

Application of this method is the same as the subjective version of the discharge ratio method except the discharge ratio curve is drawn as a linear interpolation of the discharge ratios computed for the discharge measurements.

For this study discharge was compiled using the Kfactor equation. The $\mathrm{K}$-factor was computed using the ratio of the measured discharge and the indicated openwater discharge for the mean gage height during the measurement. A linear interpolation K-factor line was drawn and used to adjust the indicated open-water discharges.

\section{Backwater Shift}

Application of this method is the same as the subjective version of the backwater shift method, except the backwater shift curve is a linear interpolation between the backwater shifts indicated by the measurements.

For this study the backwater shifts were computed and plotted on rectangular-coordinate paper. A linear interpolation backwater shift curve was drawn and this curve was merged with the shifts that were used to compute the open-water periods before and after the ice-affected period. The estimated discharges were then obtained using the backwater shift curve and the stagedischarge rating.

\section{Stage Fall}

The stage-fall method uses auxiliary gage height to adjust the indicated open-water discharge for the change in stage (fall) over a given stream reach (Carey, 1967). The method uses the derived relations between gage height and discharge, and gage height and fall for the least-backwater conditions. The least backwater rating curve is drawn as the lower bound through all iceaffected discharge measurements. Carey (1967) proposed use of a third relation between the ratio of 
discharge to least-backwater discharge, and the ratio of fall to least-backwater fall.

For this study, the required relations were developed using most of the discharge measurements made during the study. Discharge measurements that were not made at the usual measuring location were omitted. The use of historical data was not possible, because auxiliary gage data was not collected prior to this study. Because the discharge ratio versus fall ratio relations were not well defined, the theoretical square-root relation of discharge to fall was used (Rantz and others, 1982). The ice-affected streamflow record was computed using daily average values of gage-height, fall computed from the once-daily values of auxiliary gage height, and the derived relations.

\section{Adjusted Rating Curve}

The adjusted rating curve method is based on a modification of the open-water rating curve to compensate for increased slope of the rating curve due to the roughness of the ice cover. Using Manning's equation, Lavender (1984) derived the following equation relating the slope of the ice-cover rating-curve to the slope of the open-water rating-curve:

$$
\frac{d H_{i}}{d Q}=\left[1+\left(n_{i} / n_{b}\right)^{3 / 2}\right]^{2 / 5} \frac{d H_{o}}{d Q}
$$

where

$H$ is the open-water gage height,

$H_{i}^{\mathrm{o}}$ is the ice-affected gage height,

$Q$ is discharge,

$n_{b}$ is the bed roughness, and

$n_{i}$ is the ice cover roughness.

For given ice-affected discharge measurements the shift of the ice-cover rating curve can be established, thus an ice-cover rating curve can be derived from the new position and the adjusted slope.

Roughness for the ice cover and the streambed are determined by separating the vertical velocity profile into two parts. The part from the ice cover to the point of maximum velocity is influenced by the ice roughness; likewise, the bed roughness determines the shape of the velocity profile from the streambed up to the point of maximum velocity. The point of maximum velocity is determined by fitting a flexible, general twopower velocity law to the velocity data. For each part of the velocity profile, the roughness is computed from the maximum and mean velocities (Larsen, 1966; Davar and MacGougan, 1984; Gogus and Tanticlaux, 1980, 1981; Calkins and others, 1980, 1982). The composite roughness for the entire channel is computed using the Sabaneev formula (Nedzhikhovskiy, 1964; Davar and MacGougan, 1984), and averaged across the cross sec- tion using the Pratte formula (Pratte, 1979; Davar and MacGougan, 1984).

For this study, the position of the ice-affected rating curve was determined for each discharge measurement; the shift is prorated by time for the period between measurements. Roughness ratios are computed using the vertical velocity profiles obtained during the 6-week discharge measurements, and the ratios are prorated by time between measurements. The ice-affected streamflow record is determined from the updated daily ice-affected rating curve and daily average gage height.

\section{Conductance Correlation}

The conductance correlation method is based on a statistical relation between discharge and specific conductance. Specific conductance generally is inversely related to streamflow. This is due to the higher conductance of the portion of streamflow resulting from groundwater inflow than the portion resulting from surface flow (Hem, 1985). The relation between streamflow and conductance is developed from historical data using regression analysis techniques.

For this study, measured discharge and specific conductance for the 1984-86 ice-affected periods were used to develop regression equations (table 3). Daily discharge was computed using a record of once-daily conductance values.

\section{Multiple Regression}

The multiple regression method uses a regression relation established for each site to relate ice-affected discharge to selected hydrologic and climatological variables (Fontaine, 1983). The explanatory variables used include gage height, indicated open-water discharge, concurrent daily discharge at correlated stations, maximum and minimum daily air temperature, maximum and minimum monthly air temperature, total precipitation, the previous day's total precipitation, and heating degree days for the month. Measured discharge is the dependent variable for the developed equations.

For this study the regression relations were determined using data collected for the 1977-87 ice-affected periods. The regressions were conducted using a stepwise multiple regression procedure, and were limited to four explanatory variables. For each site three correlated stations were selected; only one correlated station was used in the final equation (fig. 1). All of the regressions had significance levels less than $0.001(\mathrm{p}<.001)$, and standard errors that ranged from 11 to 33 percent (table 4). The ice-affected streamflow record was computed using the fitted regression equation and values of the pertinent variables. 


\section{Index Velocity}

The index velocity method uses stream velocity and effective cross-sectional area of the channel to compute stream discharge (Strilaeff, 1972). The effective crosssectional area of the channel is the difference between total cross-sectional area and the cross-sectional area of the ice cover. Velocity is monitored continuously during the ice-affected period, and effective cross-sectional area is determined at the velocity monitoring point. Discharge is computed as the product of mean velocity and effective cross-sectional area.

For this study, stream velocity was monitored using a single velocity probe locaied at a representative point in the stream cross-section. Mean velocity was computed by adjusting the point velocity by the ratio of mean velocity for the 6-week discharge measurements to the concurrent recorded point velocity, and the ratio was prorated by time between measurements. The relation between stage and total cross-sectional area and the cross-sectional area of the ice were defined by the discharge measurements. The cross-sectional area of the ice was prorated by time between the 6-week discharge measurements. The effective cross-sectional area was computed as the difference between total crosssectional area and cross-sectional area of the ice cover. Mean daily discharge was computed as the product of mean velocity and effective cross-sectional area determined for the daily mean gage height.

\section{Ice Adjustment Factor}

The ice adjustment factor method uses the concept of a stable ice cover for determination of discharge. For stable conditions, the ratio of open-water to ice-cover hydraulic mean depth, the ice adjustment factor, is assumed to be constant (Santeford and Alger 1984, 1986a, 1986b; Alger and Santeford 1984, 1987). The icecover hydraulic mean depth is determined from an adjusted gage height and a table of gage height versus hydraulic mean depth. The recorded gage height is adjusted using the float depth to give the effective crosssectional area.

Development of the method involves estimating float depth and the ice adjustment factor for discharge measurements. By definition, float depth is the difference between recorded gage height and the equivalent gage height resulting in the effective cross-sectional area:

where

$$
F D=G H_{r}-G H_{i}
$$

$F D$ is the float depth,

$G H_{\text {is }}$ is the recorded gage height, and

$\mathrm{GH}_{i}^{r}$ is the equivalent ice gage height.

The ice adjustment factor is computed from the equivalent open-water hydraulic mean depth and the hydraulic mean depth corresponding to $\mathrm{GH}_{i}$ :

where

$$
I A F=\frac{D_{o}}{D_{i}}
$$

$I A F$ is the ice adjustment factor,

$D$ is the open-water hydraulic mean depth, and $G H_{i}$

$D_{i}^{\circ}$ is the hydraulic mean depth corresponding to

Discharge is compiled using previously estimated float depths and ice-adjustment factors, and the recorded gage height. The equivalent ice gage height is obtained by rearranging eq. (4):

$$
G H_{i}=G H_{r}-F D
$$

The ice-cover hydraulic mean depth is obtained from a table of hydraulic properties (gage height versus area and hydraulic mean depth). The equivalent open-water hydraulic mean depth is found by rearranging eq. (5):

$$
D_{o}=I A F \bullet D_{i}
$$

Table 3. - Regression equations used for the conductance correlation method $[<$, less than ]

\begin{tabular}{llccc}
\hline Station & Equation & R-squared & $\begin{array}{c}\text { Standard } \\
\text { error" } \\
\text { (percent) }\end{array}$ & $\begin{array}{c}\text { Significance } \\
\text { level (p) }\end{array}$ \\
\hline Clear Creek & $Q_{n}=228,000(1 / K)-346$ & 0.9298 & 40 & $<0.001$ \\
Des Moines River & No significant relationship & - & - & - \\
Floyd River & $Q_{n}=1,610,000(1 / K)-1,450$ & .9812 & 27 & $<.001$ \\
\hline
\end{tabular}

" $Q_{m}$ is measured discharge, in cubic feet per second, and $K$ is specific conductance, in microsiemens per centimeter

" Expressed as a percent of the mean measured discharge 
For this study the ice adjustment factor and float depth were determined for each ice-affected discharge measurement, and prorated by time between measurements. Because the cross sections changed between measurements, the tables of hydraulic properties were prorated from a measurement made before ice-cover formation and one made after spring breakup. The iceaffected streamflow record is computed using the hydraulic property and stage-discharge rating tables, the interpolated values of ice adjustment factor and float depth, and daily average values of gage height.

\section{Pipe Flow}

The pipe flow method computes streamflow under an ice cover as closed-conduit flow (Carey, 1967). The Darcy-Weisbach equation is used, with a modified friction factor based on water surface slope:

$$
Q=\sqrt{\frac{8 g}{f_{m o d}}} A R^{1 / 2} S^{1 / 2}
$$

where

$Q$ is discharge,

$g$ is the acceleration of gravity,

$f_{\text {mod }}$ is the modified friction factor,

$A^{\text {mod }}$ is the effective cross-sectional area,

$R \quad$ is the hydraulic radius, and

$S$ is the water-surface slope.

Using regression analyses, relations of $f_{\bmod }$ to $S$ and $A R^{1 / 2}$ to gage height are defined.

For this study the regression equations were developed using most of the measurements made during the 1987-88 ice-affected period. Discharge measurements that were not made at the usual measuring location were omitted. Water-surface slope was computed using data from the auxiliary gage. The ice-affected streamflow record is compiled using the defined relations, the Darcy-Weisbach equation, daily mean values of gage height, and once-daily auxiliary gage height values.

\section{Uniform Flow}

The uniform flow method uses Manning's equation to compute streamflow during periods of ice effect. Bed and ice-cover roughnesses are determined from vertical velocity profiles (see the "adjusted rating curve method" section), and are prorated between measurements. The total cross-sectional area is determined using a table of cross-sectional area versus gage height. Effective crosssecíional area is computed from total area and an estimate of ice area. The hydraulic radius is determined using a table of cross-sectional area versus gage height, with gage height adjusted to give the effective flow area.

For this study, ice roughness and ice cross-sectional area were determined for each discharge measurement. Ice roughness values were distributed using a linear interpolation by time, and bed roughness was assumed to remain constant. Ice cross-sectional area was interpolated by time between measurements during the iceaffected period. The ice-affected streamflow record was computed using Manning's equation, ice and bed roughness, effective cross-sectional area, and daily average gage height.

\section{EVALUATION OF METHODS}

In this section the various methods are evaluated on the basis of accuracy and other criteria related to operation of the U.S. Geological Survey streamflow-gaging network. Accuracy was evaluated by comparing the method results to baseline data for three streamflow gaging stations in lowa. Additional criteria include

Table 4.- Regression equations used for the multiple regression method $[<$, less than $]$

\begin{tabular}{llccc}
\hline Station & Equation* $^{*}$ & R-squared & $\begin{array}{c}\text { Standard } \\
\text { error** } \\
\text { (percent) }\end{array}$ & $\begin{array}{c}\text { Significance } \\
\text { level }\end{array}$ \\
\hline Clear Creek & $Q_{n}=0.821 Q_{t}+1.41 T_{m u n}+0.735 Q_{d}+0.752 T_{\max }-55.8$ & 0.9910 & 23 & $<0.001$ \\
Des Moines River & $Q_{n}=1.52 Q_{d}+0.471 Q_{t}+5.92 T_{m n}-23.0$ & .9962 & 11 & $<.001$ \\
Floyd River & $Q_{n}=1.91 Q_{t}-552 G+0.047 Q_{d}+4.77 t_{\max }+5,440$ & .9783 & 33 & $<.001$ \\
\hline
\end{tabular}

* $Q_{m}$ is measured discharge, $Q$ is indicated open-water discharge, $Q_{d}$ is concurrent daily discharge at a correlated station, $G$ is mean daily gage height, $T_{m n}$ is minimum monthly air temperature, $T_{m a x}$ is maximum monthly air temperature, and $t_{\max }$ is maximum daily air temperature

** Expressed as a percent of the mean measured discharge

*** The significance level of the regression 
factors that are not easily quantified, but are important considerations that influence potential use of a method.

Several factors influence the applicability of a given method. The criteria considered in this section include the following: ered;

(1) Accuracy - several measures of error are consid-

(2) cost - the time and difficulty required to collect data for the method, as well as data required in addition to the usual parameters collected at a gaging station;

(3) technical soundness - the theoretical basis and the assumptions that affect the reliability of the method;

(4) ice conditions - application of the method to various ice conditions;

(5) application to computers - an evaluation of whether the method could be used to compile records by automated data processing; and

(6) feasibility - applicability of the method to the existing U.S. Geological Survey streamflow-gaging network.

\section{ACCURACY}

Each selected method was used to estimate discharge at three sites in lowa, and compared to the baseline streamflow records to assess the accuracy of each method. The evaluation of the methods was based on typical U.S. Geological Survey data-collection procedures. Because streamflow-gaging field trips are normally made at 6-week intervals, the selected methods were evaluated using only the field information for gage visits made at this interval. A 6-week field-trip interval was reconstructed based on the pattern of field trips made during the previous year. Discharge measurements that coincided with the 6-week interval were provided for the evaluation. Two discharge measurements during the ice-affected period for each of the three streamflow-gaging stations were used for evaluating each method.

The subjective methods were applied independently by three hydrographers who are experienced at making ice-affected streamflow estimates. Two of the three hydrographers are stationed in the Iowa District and are familiar with the streamflow-gaging stations used in the study and the local hydrology; the other hydrographer is stationed in the Wisconsin District and was not familiar with the streamflow-gaging stations or the local hydrology. The subjective methods were released to the test participants in the order of increasing data requirements, with a 1-week time lapse scheduled between method evaluations. All of the participants were provided with the dates of the ice-affected periods so that the evaluation would be a comparison of method accuracy rather than an evaluation of the hydrographers' ability to recognize ice effect. The analytical methods were applied by the authors because the results are not dependent on the interpretation of the individual applying the method.

Application of the methods using different procedures or using sites with different hydrologic or hydraulic characteristics than the test sites may produce varying results. Although the hydrographers were familiar with the principles of all the methods used, they were not always familiar with method application and some improvement in the accuracy of the results may be obtained with repetitive application of the method. The test used data collected at a normal 6-week measurement schedule. The accuracy of a specific method may be improved by adjusting the timing of the schedule for that method.

Several measures of error were used to evaluate the accuracy of the methods: the percent error for the mean discharge for the ice-affected periods, the mean and standard deviation of the daily errors, and the distribution of daily errors. Statistical tests were performed to evaluate the differences between the selected methods and the baseline record.

A comparison of the estimated average discharge for the ice-affected periods with the baseline average was considered in the evaluation of the methods. Average discharge values are shown in table 5. The relative error for the daily discharge values was also computed for each method, and the results are summarized in table 6 . In table 6 , the relative error is defined as follows:

$$
\varepsilon=\frac{Q_{e}-Q_{b}}{Q_{b}}
$$

where

$\varepsilon$ is relative error,

$Q_{e}$ is the daily estimated discharge, and

$\mathrm{Q}_{\mathrm{b}}$ is the daily baseline discharge.

The mean relative error is an indication of the overall bias of the method, which is a consistent tendency to either over-or underestimate daily discharge. A method with a significant bias will have cumulative errors for monthly and yearly means regardless of the magnitude of the variability of the error. The distribution of relative errors for the daily discharge values are listed for selected ranges in error, and summarized in table 7 . For publication purposes, daily discharge values that are within 5 percent of the true discharge are rated "excellent"; within 10 percent are rated "good"; within 15 percent are rated "fair"; records that are not within 15 percent of the true discharge are rated "poor" (Novak, 1985).

The standard deviation of the daily relative error indicates the variability in the errors. The standard deviation of the daily relative error would equal the root mean square error for each method provided the baseline record was equal to the true daily discharge and discharge was independent from day to day. Although 
daily discharges are not independent and the baseline record contains some uncertainty, the standard deviation does give an indication of the variability to be expected for a given method, and can be used to compare different methods to one another. For example, the results for Clear Creek (table 6) indicate that the the errors associated with the uniform flow technique (43 percent) are considerably smaller than the corresponding errors for the prorated discharge technique (454 percent).

The distribution of daily errors is another important consideration in the evaluation of a given method. A method may have a relatively low bias and standard deviation, however the method may provide an occasional estimate with an extremely large error. This could be caused by the inability to compute discharge for a

Table 5. - Average discharge for the ice-affected period determined by each method and percent error compared to the average baseline discharge $[-$, not computed $]$

\begin{tabular}{|c|c|c|c|c|c|c|}
\hline \multirow[b]{2}{*}{ Method ${ }^{1}$} & \multicolumn{2}{|c|}{ Clear Creek } & \multicolumn{2}{|c|}{ Des Moines River } & \multicolumn{2}{|c|}{ Floyd River } \\
\hline & $\begin{array}{c}\text { Average } \\
\text { discharge }\end{array}$ & $\begin{array}{c}\text { Percent } \\
\text { error }\end{array}$ & $\begin{array}{l}\text { Average } \\
\text { discharge }\end{array}$ & $\begin{array}{c}\text { Percent } \\
\text { error }\end{array}$ & $\begin{array}{c}\text { Average } \\
\text { discharge }\end{array}$ & $\begin{array}{c}\text { Percent } \\
\text { error }\end{array}$ \\
\hline \multirow[t]{2}{*}{ Baseline record } & 68 & - & 290 & - & 170 & - \\
\hline & \multicolumn{6}{|c|}{ Subjective methods } \\
\hline Base-flow recession (1) & 45 & -34 & 260 & -10 & 130 & -24 \\
\hline Base-flow recession (2) & 38 & -44 & 280 & -3.4 & 86 & -49 \\
\hline Base-flow recession (3) & 50 & -26 & 310 & 6.9 & 160 & -5.9 \\
\hline Discharge ratio (1) & 64 & -5.9 & 270 & -6.9 & 130 & -24 \\
\hline Discharge ratio (2) & 65 & -4.4 & 290 & 0 & 130 & -24 \\
\hline Discharge ratio (3) & 79 & 16 & 310 & 6.9 & 210 & 24 \\
\hline Backwater shift (1) & 83 & 22 & 270 & -6.9 & 230 & 35 \\
\hline Backwater shift (2) & 77 & 13 & 310 & 6.9 & 260 & 53 \\
\hline Backwater shift (3) & 74 & 8.8 & 320 & 10 & 220 & 29 \\
\hline Interpolated discharge (1) & 54 & -21 & 290 & 0 & 130 & -24 \\
\hline Interpolated discharge (2) & 92 & 35 & 270 & -6.9 & 110 & -35 \\
\hline Interpolated discharge (3) & 87 & 28 & 290 & 0 & 140 & -18 \\
\hline Adjusted discharge (1) & 67 & -1.5 & 280 & -3.4 & 170 & 0 \\
\hline Adjusted discharge (2) & 45 & -34 & 260 & -10 & 100 & -41 \\
\hline Adjusted discharge (3) & 60 & -12 & 330 & 14 & 230 & 35 \\
\hline Hydrographic-and-climatic comparison (1) & 59 & -13 & 270 & -6.9 & 140 & -18 \\
\hline Hydrographic-and-climatic comparison (2) & 53 & -22 & 290 & 0 & 160 & -5.9 \\
\hline \multirow[t]{2}{*}{ Hydrographic-and-climatic comparison (3) } & 67 & -1.5 & 270 & -6.9 & 200 & 18 \\
\hline & \multicolumn{6}{|c|}{ Analytical methods } \\
\hline Prorated discharge & 151 & 120 & 330 & 14 & 260 & 53 \\
\hline Discharge ratio & 70 & 2.9 & 270 & -6.9 & 280 & 65 \\
\hline Backwater shift & 75 & 10 & 320 & 10 & 300 & 76 \\
\hline Stage fall & 52 & -24 & - & - & 240 & 41 \\
\hline Adjusted rating curve & 76 & 12 & 280 & -3.4 & 180 & 5.9 \\
\hline Conductance correlation & 79 & 16 & - & - & 550 & 220 \\
\hline Multiple regression & 119 & 75 & 340 & 17 & 380 & 120 \\
\hline Index velocity & 79 & 16 & 300 & 3.4 & - & - \\
\hline Ice adjustment factor & 95 & 40 & 310 & 6.9 & 220 & 29 \\
\hline Pipe flow & 117 & 72 & - & - & 110 & -35 \\
\hline Uniform flow & 76 & 12 & - & - & 160 & -5.9 \\
\hline
\end{tabular}

${ }^{1}$ The number in parentheses indicates the hydrographer who compiled the estimated record 
temporary set of ice conditions. An overall representation of the daily relative errors is shown in figure 3 , and the percent distribution for selected error ranges is shown on table 7 . To further aid in the interpretation of the results, the estimated and baseline hydrographs are shown in figures 4 to 6 .

A comparison was made for each method to determine if the estimated daily discharges were statistically different from the baseline daily discharges. Tests for normality revealed that none of the time series followed a normal distribution, thus a nonparametric equivalent to a paired t-test, the Wilcoxon signed-rank test (Conover, 1971), was used to test for differences between estimated and baseline discharge. The test was modified to account for serial correlation(ElShaarawi and Damsleth, 1988), and applied to the time series for each method. The results are reported in table 8 , and will be discussed for each method in subsequent sections.

Statistical analyses were performed for the six subjective methods to analyze the variability of the results between the three hydrographers. Because the time series do not follow a normal distribution, the Kruskal-

\section{Table 6. - Statistical summary of the error between estimated daily discharge and baseline daily discharge}

[The statistics are computed over the ice-affected period(s). —, not computed.]

\begin{tabular}{|c|c|c|c|c|c|c|}
\hline \multirow[b]{2}{*}{ Method $^{1}$} & \multicolumn{2}{|c|}{ Clear Creek } & \multicolumn{2}{|c|}{ Des Moines River } & \multicolumn{2}{|c|}{ Floyd River } \\
\hline & Mean & $\begin{array}{l}\text { Standard } \\
\text { deviation }\end{array}$ & Mean & $\begin{array}{l}\text { Standard } \\
\text { deviation }\end{array}$ & Mean & $\begin{array}{l}\text { Standard } \\
\text { deviation }\end{array}$ \\
\hline & & & \multicolumn{2}{|c|}{ Subjective methods } & & \\
\hline Base-flow recession (1) & -0.01 & 0.41 & -0.05 & 0.23 & -0.09 & 0.31 \\
\hline Base-flow recession (2) & -.10 & .45 & .09 & .31 & -.02 & .50 \\
\hline Base-flow recession (3) & .06 & .44 & .13 & .24 & .16 & .38 \\
\hline Discharge ratio (1) & .21 & .36 & -.02 & .24 & -.09 & .28 \\
\hline Discharge ratio (2) & .19 & .37 & .04 & .22 & .00 & .29 \\
\hline Discharge ratio (3) & .31 & .52 & .05 & .25 & .16 & .30 \\
\hline Backwater shift (1) & .34 & .48 & -.12 & .31 & .23 & .44 \\
\hline Backwater shift (2) & .24 & .45 & .02 & .28 & .30 & .52 \\
\hline Backwater shift (3) & .22 & .45 & .09 & .23 & .39 & .49 \\
\hline Interpolated discharge (1) & -.01 & .28 & .02 & .17 & -.05 & .22 \\
\hline Interpolated discharge (2) & .33 & .53 & -.04 & .15 & -.12 & .25 \\
\hline Interpolated discharge (3) & .43 & .87 & .06 & .21 & -.05 & .23 \\
\hline Adjusted discharge (1) & .24 & .43 & -.01 & .16 & .03 & .30 \\
\hline Adjusted discharge (2) & -.05 & .37 & -.05 & .22 & -.15 & .27 \\
\hline Adjusted discharge (3) & .09 & .36 & .14 & .22 & .27 & .40 \\
\hline Hydrographic-and-climatic comparison (1) & .13 & .40 & -.04 & .17 & -.01 & .24 \\
\hline Hydrographic-and-climatic comparison (2) & .06 & .41 & .05 & .21 & -.02 & .26 \\
\hline \multirow[t]{2}{*}{ Hydrographic-and-climatic comparison (3) } & .18 & .41 & -.03 & .17 & .14 & .36 \\
\hline & \multicolumn{6}{|c|}{ Analytical methods } \\
\hline Prorated discharge & 2.50 & 4.54 & .18 & .28 & 1.11 & 1.93 \\
\hline Discharge ratio & .31 & .54 & -.02 & .27 & .71 & .58 \\
\hline Backwater shift & .21 & .54 & .08 & .29 & .78 & .72 \\
\hline Stage fall & .07 & .34 & - & - & 1.63 & 1.26 \\
\hline Adjusted rating curve & .40 & .54 & -.01 & .23 & -.10 & .37 \\
\hline Conductance correlation & .02 & 1.14 & - & - & 1.85 & 2.81 \\
\hline Multiple regression & 1.14 & .65 & .18 & .24 & 1.73 & 1.00 \\
\hline Index velocity & .28 & .51 & .04 & .18 & - & - \\
\hline Ice adjustment factor & .48 & .55 & .04 & .28 & .32 & .36 \\
\hline Pipe flow & .07 & .79 & - & - & .13 & .50 \\
\hline Uniform flow & .35 & .43 & - & - & .01 & .26 \\
\hline
\end{tabular}

\footnotetext{
${ }^{1}$ The number in parentheses indicates the hydrographer who compiled the streamflow record.
} 
Wallis one-way analysis of variance (Conover, 1971) was used to evaluate the method results (table 9). The significance levels in this table represent the probability of a difference between the hydrographers being attributed to random chance. Thus, probabilities less than a chosen significance level $(0.025)$ indicate inconsistent results for the three hydrographers, and probabilities that exceed the significance level indicate consistent results for the three hydrographers. For example, the three hydrographers produced statistically similar $(\mathrm{p}=$ .520) results for Clear Creek using the discharge ratio method, whereas the three hydrographers produced statistically different $(\mathrm{p}<.001)$ results using the interpolated discharge method.

The statistics included in this report are intended to be a general comparison of method accuracy, and should not be considered an absolute determination of the accuracy of each method.

\section{SUBJECTIVE METHODS \\ Base-flow Recession}

The base-flow recession method underestimated the baseline mean for the ice-affected periods for eight of the nine record compilations (three streams and three hydrographers). The average percent error between the method mean and the baseline mean for each stream is shown in table 5 . The mean daily relative error ranged from -0.10 to 0.16 (table 6 ). The standard deviation of the daily relative errors ranged from 0.23 to 0.50 for the nine compilations (table 6). The relative error of the daily discharge values indicated that 15 percent of the daily values were excellent ( $0-5$ percent error); 28 percent were good to excellent (0-10 percent error); and 39 percent were fair to excellent $(0-15$ percent error). Forty-three percent of the daily values had relative errors between 15 and 50 percent, and 18 percent had relative relative errors greater than 50 percent (table 7). Only one of the nine discharge records was found to be significantly different $(p<.025)$ than the baseline discharge record (table 8). The three hydrographers' streamflow records were significantly different $(p<.025)$ from each other for two of the three compilations, and are marginal for the other compilation (table 9).

The base-flow recession method requires a general knowledge of ice computation techniques and an understanding of streamflow recession. Each year a recession curve must be drawn or a coefficient for a recession equation must be defined. All other materials or data needed for method application are available for the existing streamflow-gaging network. The method

Table 7.-Percentage distribution of the relative error for the daily discharge values for selected ranges in error

$[>$, greater than]

\begin{tabular}{lcccccccc}
\hline Method $^{1}$ & $0-5$ & $5-10$ & $10-15$ & $15-25$ & $25-50$ & $>50$ & \\
& per- & per- & per- & per- & per- & per- & Total \\
& cent & cent & cent & cent & cent & cent & number \\
& error & error & error & error & error & error & of days \\
& & &
\end{tabular}

Base-flow recession

Discharge ratio

Backwater shift

Interpolated discharge

Adjusted discharge

Hydrographic-and-climatic comparison

\section{Subjective methods}

$\begin{array}{rrrrrrr}15 & 13 & 11 & 19 & 24 & 18 & 636 \\ 17 & 19 & 13 & 20 & 21 & 10 & 636 \\ 21 & 16 & 16 & 19 & 18 & 10 & 636 \\ 20 & 11 & 11 & 16 & 20 & 22 & 636 \\ 23 & 18 & 11 & 15 & 20 & 13 & 636 \\ 23 & 17 & 15 & 19 & 17 & 9 & 636\end{array}$

Prorated discharge

Discharge ratio

Backwater shift

Stage fall

Adjusted rating curve

Conductance correlation

Multiple regression

Index velocity

Ice adjustment factor

Pipe flow

Uniform flow

Analytical methods

\begin{tabular}{rrrrrrl}
8 & 10 & 10 & 11 & 19 & 42 & 212 \\
9 & 9 & 12 & 16 & 21 & 33 & 212 \\
13 & 10 & 12 & 16 & 18 & 31 & 212 \\
8 & 4 & 4 & 10 & 22 & 52 & 145 \\
14 & 14 & 14 & 14 & 26 & 18 & 212 \\
0 & 3 & 1 & 4 & 17 & 75 & 145 \\
7 & 7 & 4 & 5 & 15 & 62 & 212 \\
26 & 13 & 12 & 15 & 17 & 17 & 118 \\
13 & 11 & 14 & 19 & 20 & 23 & 212 \\
15 & 12 & 10 & 19 & 20 & 24 & 145 \\
12 & 8 & 6 & 15 & 41 & 18 & 145 \\
\hline
\end{tabular}

${ }^{1}$ The subjective methods present the combined results for all three hydrographers

${ }^{2}$ Number of ice-affected days available in determining the distribution of daily relative errors 
is based on a uniform and predictable ice-affected recession. The method can be applied to all ice conditions except storm runoff periods. The equation solution to this method could be adapted to automated data processing, and the equation would be updated periodically. This method could be used for ice computations within the existing U.S. Geological Survey streamflow-gaging network.
The base-flow recession curve is based on the assumption that the winter recession is a smooth curve. The data collected for this study do not fully support that assumption. The frequent discharge measurements obtained for this study indicate that streamflow fluctuates on a daily basis. The winter recession, as defined by these measurements, is only a very general trend with many significant departures from the gen-
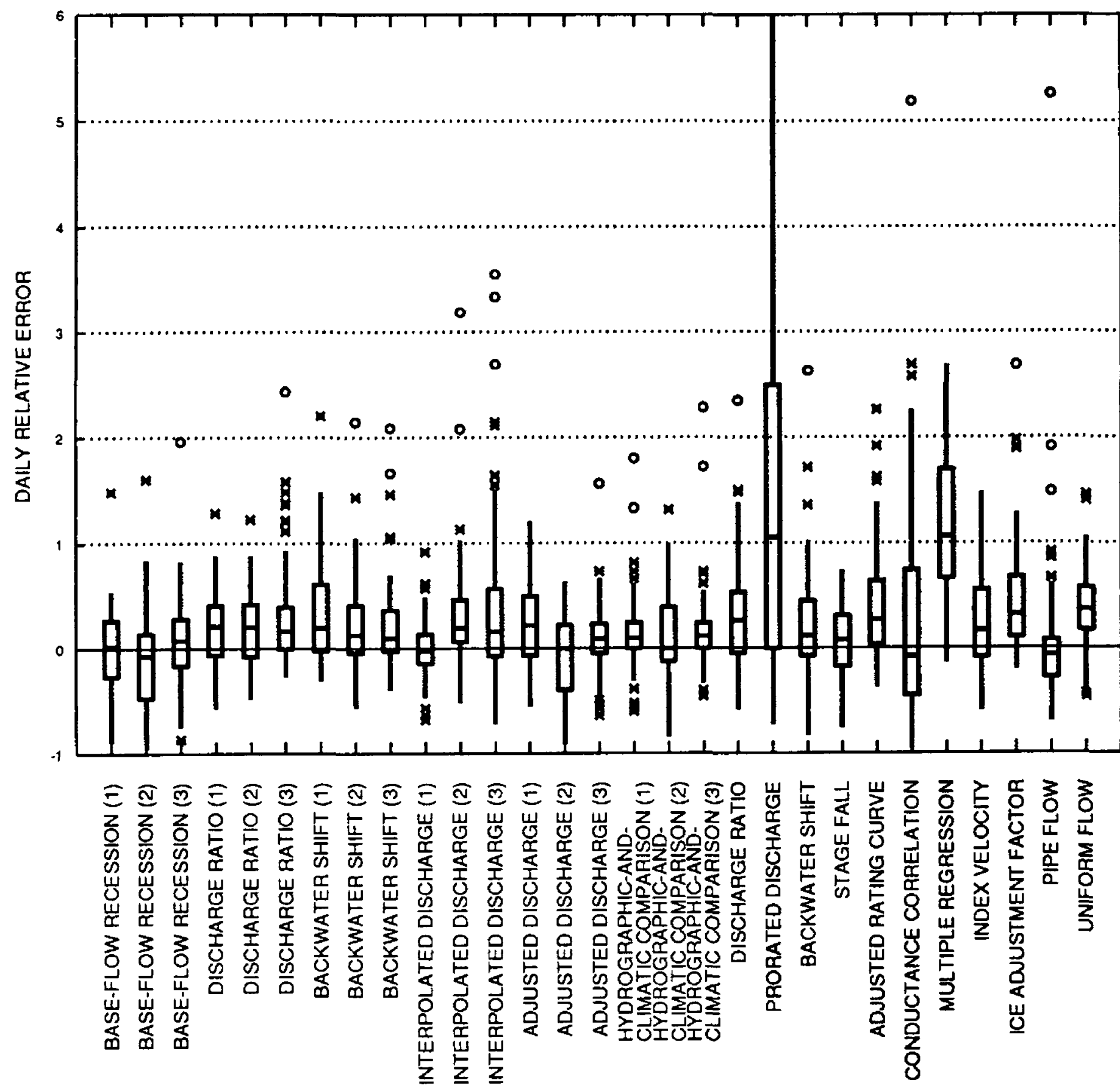

\section{EXPLANATION}

- Value exceeding $075+3.0 * \mathbb{R}$

× Value exceeding $075+1.5 * \mathbb{R}$

$\left.\begin{array}{l}\text { interquartile } \\ \text { range (IR) }\end{array}\right] \begin{aligned} & \begin{array}{l}\text { Maximum value less than } 075+1.5 * I R \\ 75 \text { th percentile }(075) \\ \text { Median } \\ 25 \text { th percentile }(025) \\ \text { Minimum value greater than } 025-1.5 * I R\end{array} \\ & \qquad \begin{array}{l}\text { Value less than } 025-1.5 * I R \\ \text { Value less than } 025-3.0 * I R\end{array}\end{aligned}$

Figure $3 A$. Summary of relative errors for selected methods applied to Clear Creek near Coralville, lowa. (Relative error is defined in the text; the number in parentheses indicates the hydrographer who compiled the streamflow record.) 
eral curve (fig. 2). The base-flow recession method probably is an oversimplification of ice-affected flow conditions, and, based on the information obtained during this study, may notbe an appropriate method for compiling ice-affected streamflow record. The method may be more appropriate for use in the northernmost latitudes of the United States where winter runoff is less frequent.

\section{Discharge Ratio}

The discharge ratio method underestimated the baseline mean for the ice-affected periods for five record compilations, overestimated the mean for three compilations, and correctly computed the baseline mean for one compilation. The average percent error between the method mean and baseline mean for each stream is
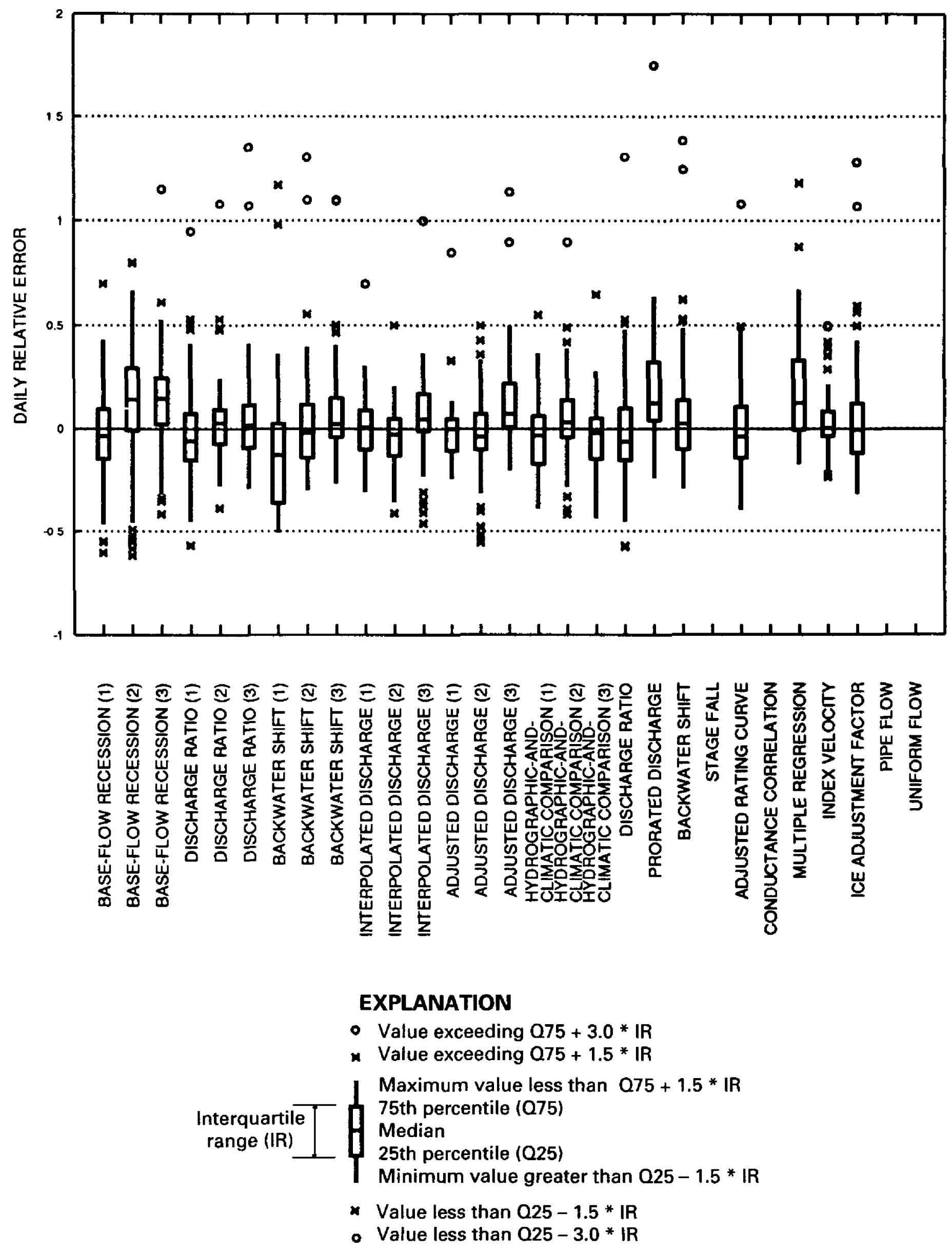

Figure 3B. Summary of relative errors for selected methods applied to the Des Moines River at Fort Dodge, Iowa. (Relative error is defined in the text; the number in parentheses indicates the hydrographer who compiled the streamflow record.) 
shown in table 5 . The mean daily relative error ranged from -0.09 to 0.31 (table 6 ). The standard deviation of the daily relative errors ranged from 0.22 to 0.52 for the nine compilations (table 6). The relative error of the daily discharge values indicated that 17 percent of the daily values were excellent ( $0-5$ percent error); 36 percent were good to excellent ( $0-10$ percent error); and 49 percent were fair to excellent (0-15 percent error).
Forty-one percent of the daily values had relative errors between 15 and 50 percent, and 10 percent had relative errors greater than 50 percent (table 7). Only one of the nine discharge records was significantly different $(\mathrm{p}<$ .025) than the baseline discharge record (table 8 ). The three hydrographers' streamflow records were significantly different $(\mathrm{p}<.025)$ from each other for one of the three compilations (table 9).
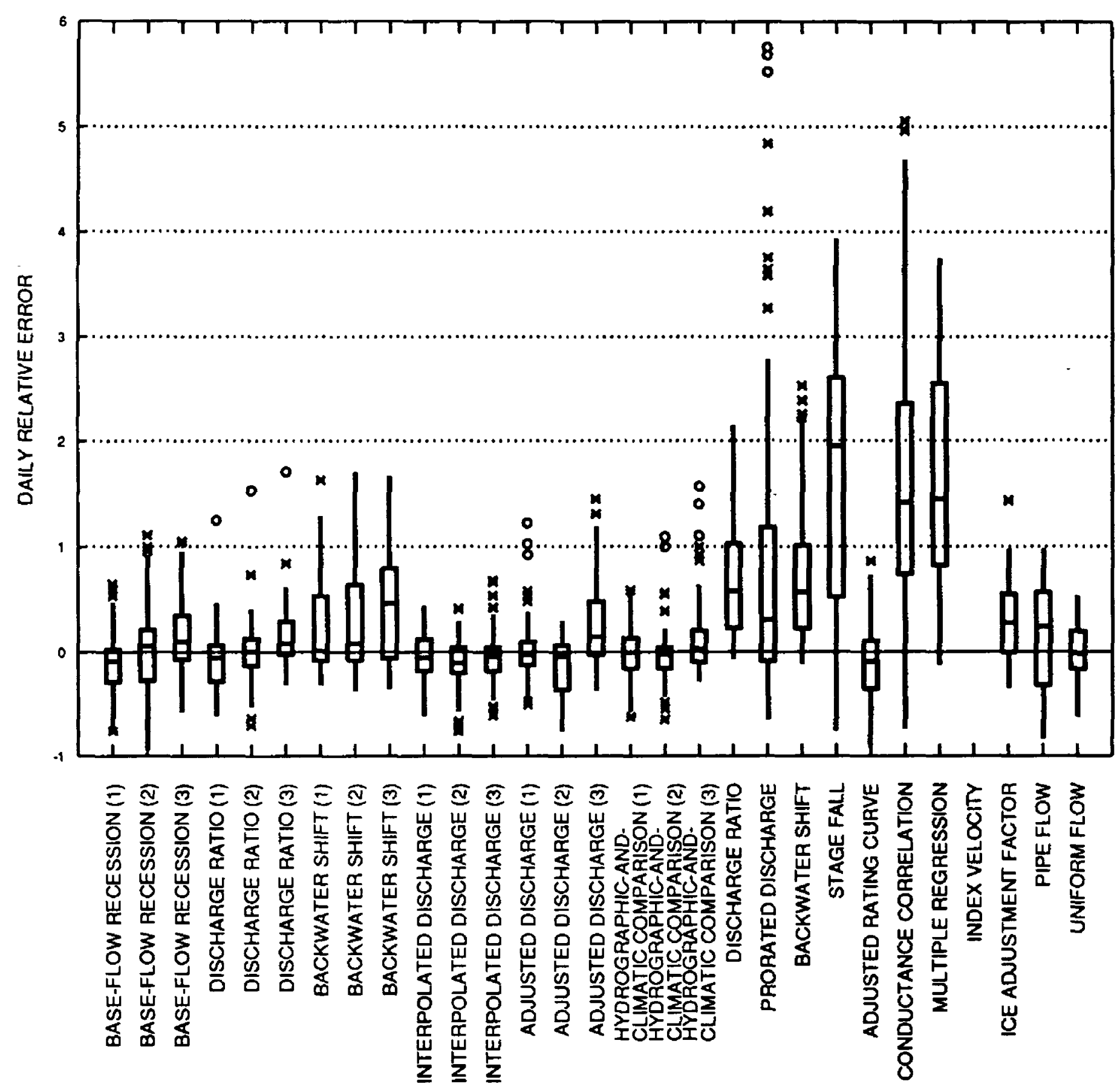

\section{EXPLANATION}

- Value exceeding $075+3.0 *$ IR

* Value exceeding $075+1.5 * I R$

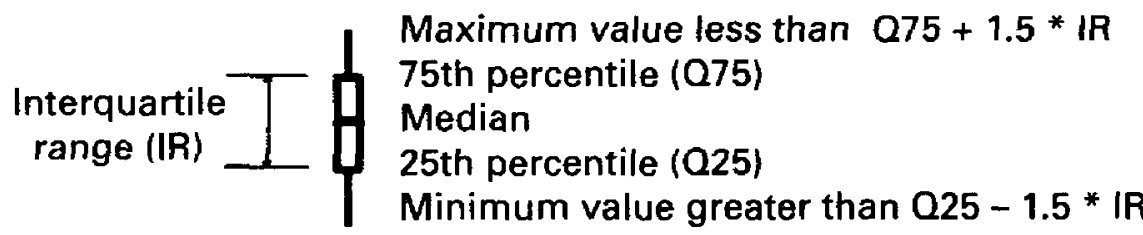

* Value less than $025-1.5$ * IR

- Value less than $025-3.0 * I R$

Figure $3 C$. Summary of relative errors for selected methods applied to the Floyd River at James, lowa. (Relative error is defined in the text; the number in parentheses indicates the hydrographer who compiled the streamflow record.) 
The discharge ratio method requires only a general knowledge of ice-affected streamflow computation techniques. The method uses a discharge ratio curve developed for each year. All other materials or data needed for method application are available for the existing streamflow-gaging network. The method depends on individual judgment and experience in determining the effects of changing meteorological conditions on the backwater curve. The method is based on the assumption that the ratio of measured to rated discharge is representative for the periods between discharge measurements. The method can be applied to all ice conditions; however, if the discharge ratio is computed for one ice condition and used to define discharge during another condition, the results may not be reliable. The method is adaptable to automated data processing, however the discharge ratio curve would have to be manually developed. All other computations could be completed by automated methods. This method could be used for ice computations within the existing U.S. Geological Survey streamflow-gaging network.

The standard deviation of the relative error and the mean discharges for each station indicate that the results of the discharge ratio compilation for each station were similar. The Kruskal-Wallis 1-way analysis of variance (table 9) shows generally consistent results for each station, indicating that the method results are fairly reproducible. The accuracy of discharge estimates obtained by the method probably would be improved as users obtained more experience at drawing the K-factor line. The scheduling of discharge measurements for optimum definition of the discharge ratio line probably would improve the method results. Given the ease of application, the reproducibility, and the consistent and comparatively accurate results of the discharge-ratio method, the method should be considered for wider use by the U.S. Geological Survey for compiling ice-affected streamflow.

\section{Backwater Shift}

The backwater shift method underestimated the baseline mean for the ice-affected periods for one record compilation and overestimated the baseline mean for eight compilations. The average percent error between the method mean and the baseline mean for each stream is shown in table 5 . The mean daily relative error ranged from -0.12 to 0.39 (table 6 ). The standard deviation of the daily relative errors ranged from 0.23 to 0.52 for the nine compilations (table 6). The relative error of the daily discharge values indicated that 21 percent of the daily values were excellent ( $0-5$ percent error); 37 percent were good to excellent ( $0-10$ percent error); and 53 percent were fair to excellent $(0-15$ percent error). Thirty-seven percent of the daily values had relative errors between 15 and 50 percent, and 10 percent had relative errors greater than 50 percent (table 7). Four of the nine discharge records were significantly different $(\mathrm{p}<.025)$ than the baseline discharge record (table 8). The three hydrographers' streamflow records were significantly different $(p<.025)$ from each other for one of the three compilations (table 9).

The backwater shift method requires only a general knowledge of ice-affected streamflow computation techniques. The method requires drawing a backwater shift curve for ice-affected periods. All other materials or data needed for method application are available for the existing streamflow-gaging network. The method depends on individual judgement and experience for determining the effects of changing meteorological conditions on the backwater curve. The method is based on the assumption that the stream backwater defined by discharge measurements is representative for the periods between measurements. This is the basis for the use of open-water shift application, but the variability of backwater from ice generally is greater during iceaffected periods. The method can be used for all ice conditions; however, if a backwater shift is computed for one ice condition and used to define discharge during another condition the results may not be reliable. The method is adaptable to automated data processing; however, the backwater-shift curve would have to be manually developed. This method could be used for ice computations within the existing U. S. Geological Survey streamflow-gaging network.

The backwater shifts computed for the 6-week discharge measurements observed during this study generally indicate backwater conditions exist only for a relatively brief period of time. Some improvement in the results for this method may be obtained as users become more experienced at drawing backwater curves. The scheduling of discharge measurements for optimum definition of the backwater-shift curve probably would improve the method results. The study results indicated that the backwater shift method has some value for determining discharge during storm runoff periods (figs. 4-6), but the backwater shift method is not appropriate for compiling most ice-affected streamflow record. The method may have some value in identifying outlier data estimated by another method. By computing the backwater shift for each ice-affected discharge that $i$ - estimated by another method, erroneous or impossible conditions may be identified.

\section{Interpolated Discharge}

The interpolated discharge method underestimated the baseline mean for the ice-affected periods for five record compilations, overestimated the baseline mean for two compilations and correctly computed the baseline mean for two compilations. The average percent erro 
between the method mean and the baseline mean for each stream is shown in table 5 . The mean daily relative error ranged from -0.12 to 0.43 (table 6 ). The standard deviation of the daily relative errors ranged from 0.15 to 0.87 for the nine compilations (table 6 ). The relative error of the daily discharge values indicated that 20 percent of the daily values were excellent $(0-5$ percent error); 31 percent were good to excellent $(0-10$ percent error); and 42 percent were fair to excellent (0-15 percent error). Thirty-six percent of the daily values had relative errors between 15 and 50 percent, and 22 percent had relative errors greater than 50 percent (table 7). Two of the nine discharge records were significantly different $(\mathrm{p}<.025)$ than the baseline discharge record (table 8). The three hydrographers' streamflow records were significantly different $(\mathrm{p}<.025)$ from each other for two of the three compilations (table 9).

The interpolated discharge method requires only a general knowledge of ice computation techniques. All other materials or data needed for method application are available for the existing streamflow-gaging network. The method is dependent on individual judgment and experience in determining the relative importance of discharge measurements and information from hydrographic comparison. The method does not rely on recorded stage or indicated open-water discharges for making discharge estimates. Method application is, therefore, simplified, but the results probably are less reliable. The method is suitable for use in all ice conditions. Because the method depends on individual judgement rather than a systematic computation, the method is not adaptable to automated data processing. The method could be applied to the existing U.S. Geological Survey streamflow-gaging network. Because ice-affected stage is not used, the method does not consider a parameter normally recorded at streamflowgaging stations.

The interpolated discharge method is similar to the hydrographic-and-climatic-comparison method but does not use the indicated open-water discharges. The method was included in the study to assess the relative value of the indicated open-water discharges. The indicated open-water discharges, therefore, are an important factor in improving the accuracy of ice-affected discharge estimates.

\section{Adjusted Discharge}

The adjusted discharge method underestimated the baseline mean for the ice-affected periods for six record compilations, overestimated the baseline mean for two compilations and correctly computed the baseline mean for one compilation. The average percent error between the method mean and the baseline mean for each stream is shown in table 5 . The mean daily relative error ranged from -0.15 to 0.27 (table 6). The standard deviation of the daily relative errors ranged from 0.16 to 0.43 for the nine compilations (table 6 ). The relative error of the daily discharge values indicated that 23 percent of the daily values were excellent $(0-5$ percent error); 41 percent were good to excellent ( $0-10$ percent error); and 52 percent were fair to excellent $(0-15$ percent error). Thirty-five percent of the daily values had relative errors between 15 and 50 percent, and 13 percent had relative errors greater than 50 percent (table 7). Two of the nine discharge records were significantly different $(p<.025)$ than the baseline discharge record (table 8). The three hydrographers' streamflow records were significantly different $(\mathrm{p}<.025)$ from each other for all three compilations (table 9), and therefore the method is not very reproducible.

The adjusted discharge method requires only a general knowledge of ice computation techniques. All other materials or data needed for method application are available for the existing streamflow-gaging network. The method depends on individual judgement and experience in determining the relative importance of discharge measurements, meteorological information and the indicated open-water discharges. Application is simplified because hydrographic comparison is not used, but the results probably are less reliable than if data from other stations were considered. The method can be applied to all ice conditions. The method is not adaptable to automated data processing because it depends on individual judgement rather than a systematic computation. The method could be applied to the existing U.S. Geological Survey streamflow-gaging network. Because the method does not consider data from other streamflow-gaging stations it does not use one of the major advantages of operating a comprehensive streamflow-gaging network.

The adjusted discharge method is similar to the hydrographic-and-climatic-comparison method but it does not use hydrographic comparison. The method was included in the study to assess the relative value of hydrographic comparison. The results indicate that hydrographic comparison is an important factor for improving the accuracy of ice-affected discharge estimates.

\section{Hydrographic-and-climatic comparison}

The hydrograpinic-and-climatic-comparison method underestimated the baseline mean for the iceaffected periods for seven record compilations, overestimated the mean for one compilation, and correctly computed the baseline mean for one compilation. The average percent error between the method mean and the baseline mean for each stream is shown in table 5 . The mean daily relative error ranged from -0.04 to 0.18 (table 6). The standard deviation of the daily relative errors ranged from 0.17 to 0.41 for the nine compila- 

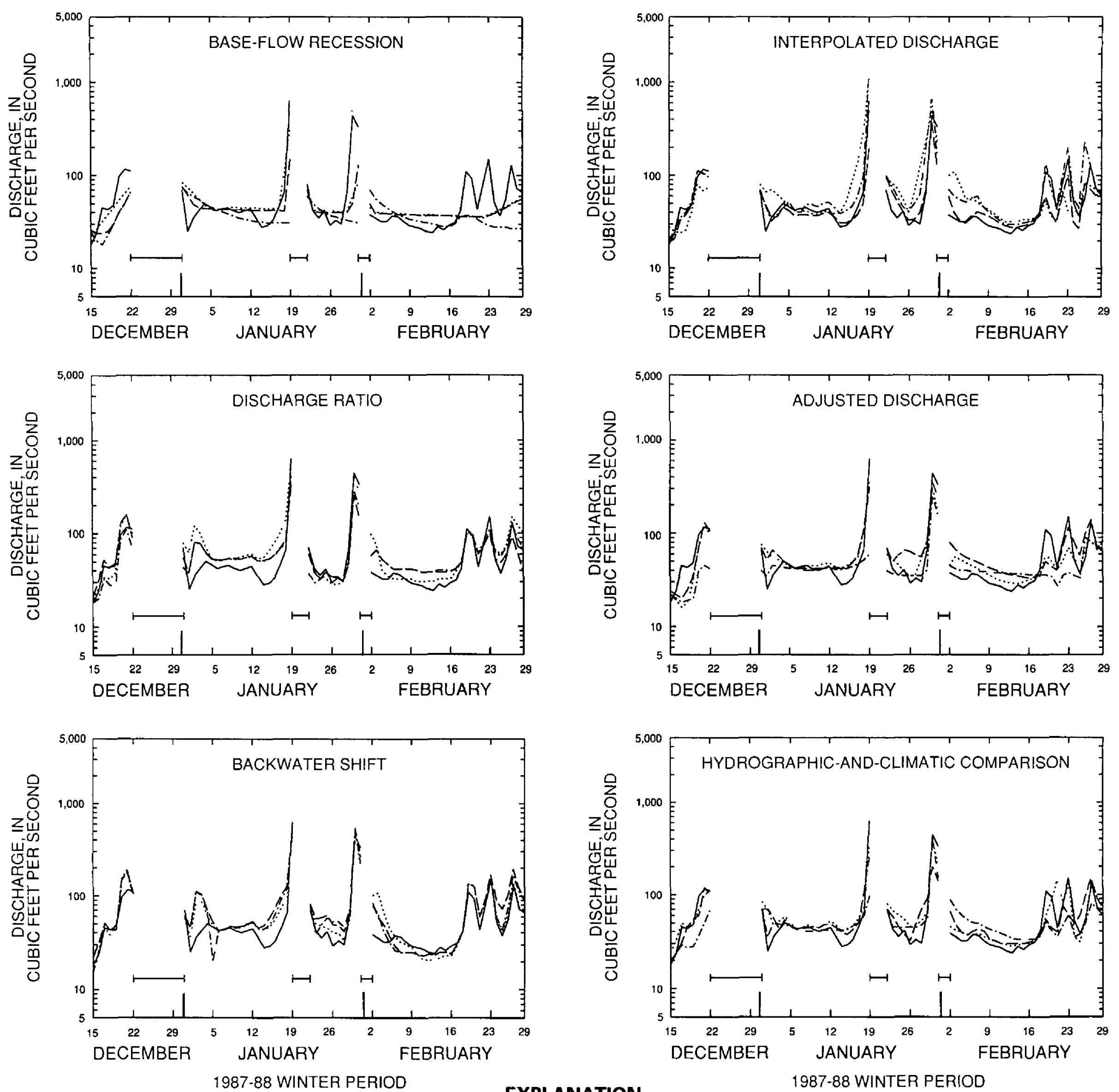

EXPLANATION

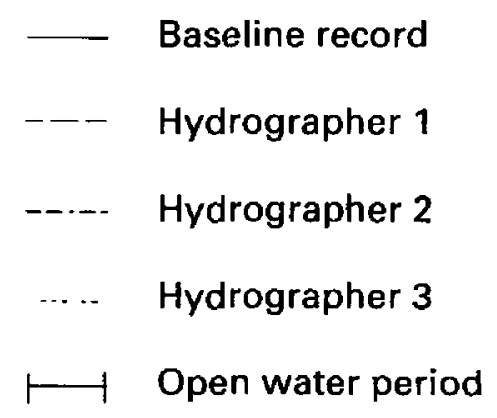

Figure 4A. Hydrographs for Clear Creek near Coralville showing baseline daily mean discharge and daily mean discharge estimated by subjective methods. 
tions (table 6). The relative error of the daily discharge values indicated that 23 percent of the daily values were excellent ( $0-5$ percent error); 40 percent were good to excellent ( $0-10$ percent error); and 55 percent were fair
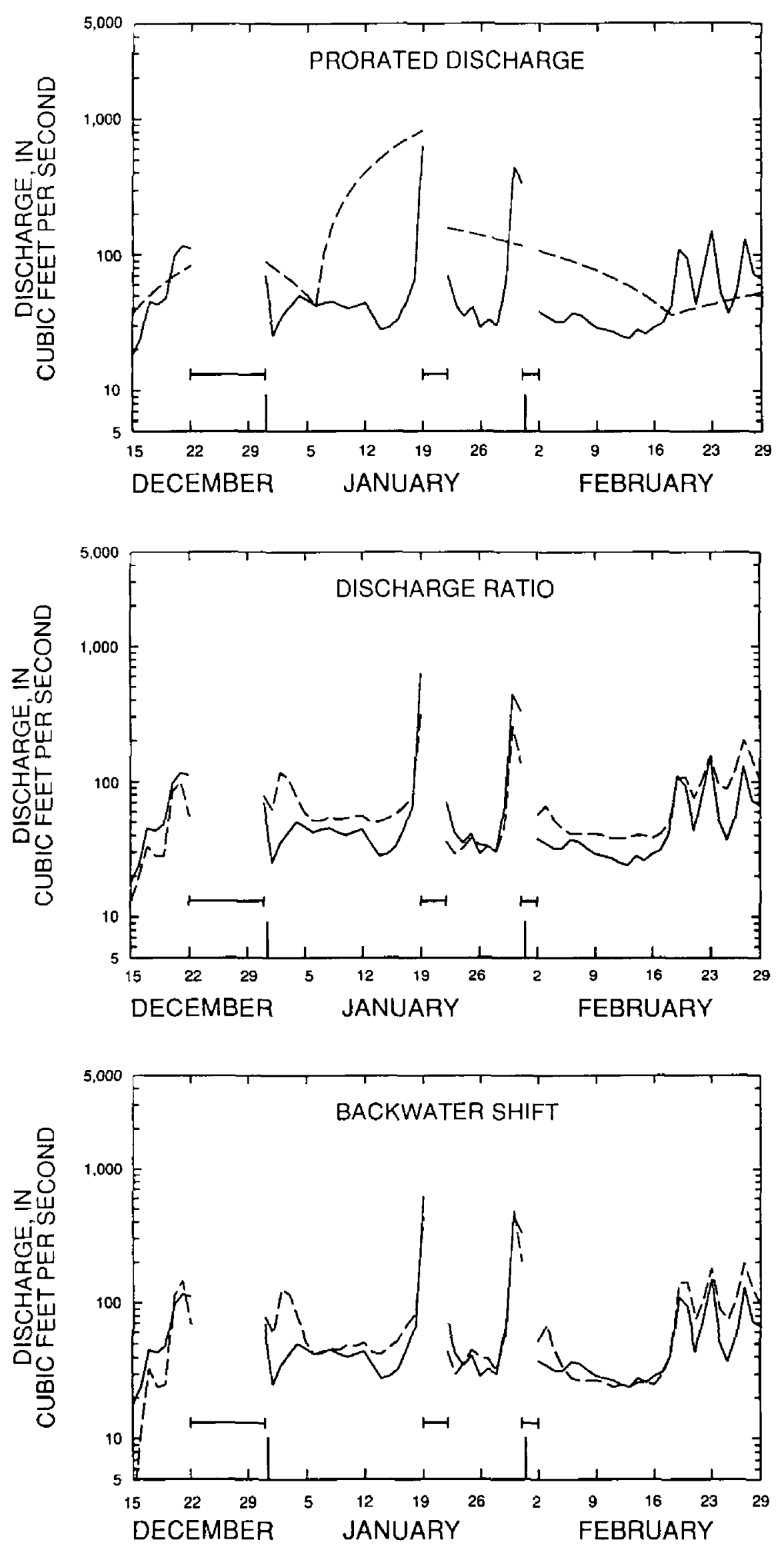

1987-88 WINTER PERIOD to excellent ( $0-15$ percent error). Thirty-six percent of the daily values had relative errors between 15 and 50 percent, and 9 percent had relative errors greater than 50 percent (table 7). Only one of the nine discharge
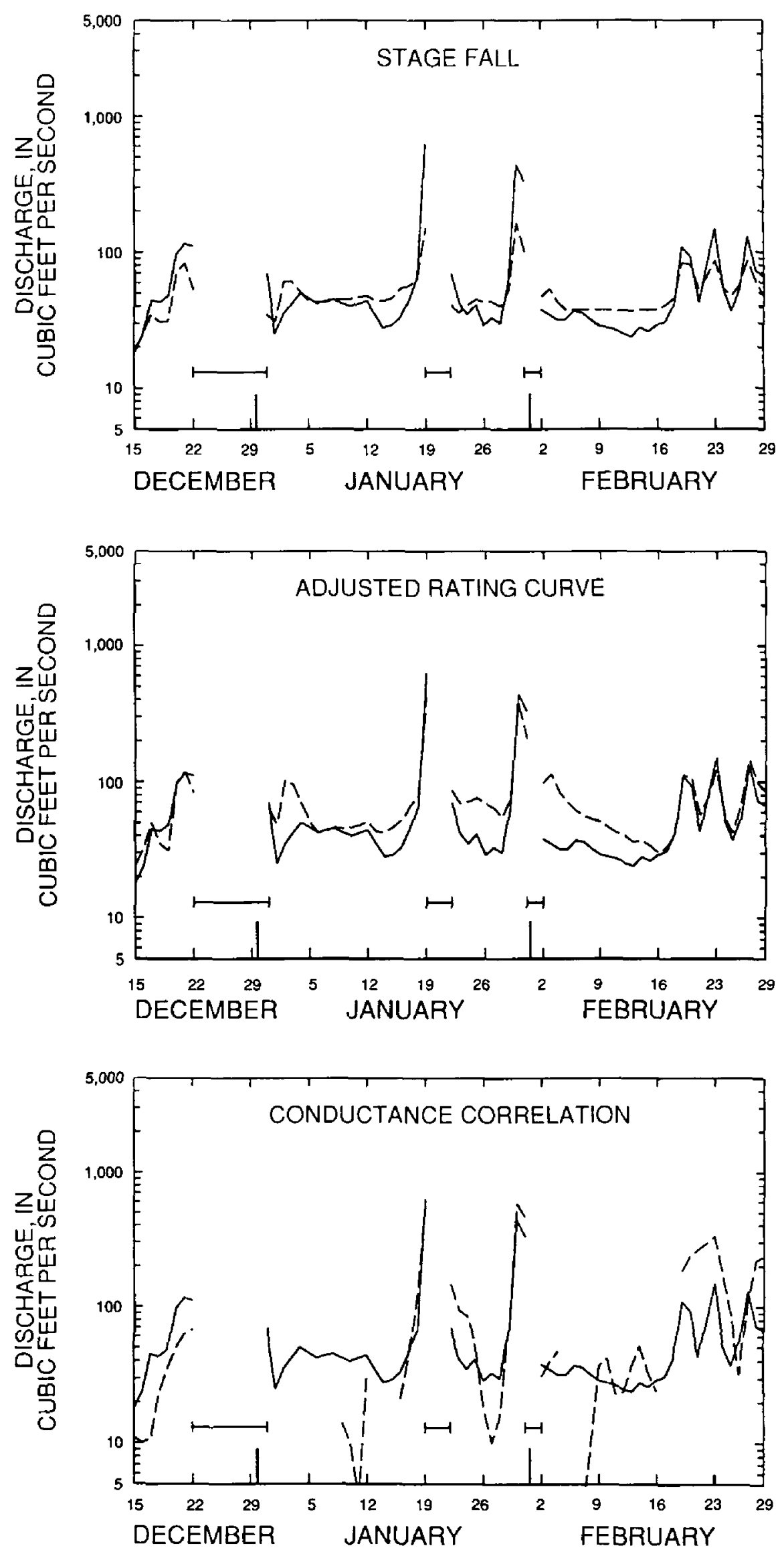

1987-88 WINTER PERIOD

\section{EXPLANATION}

\section{_ Baseline record \\ -- Estimated discharge \\ $\longmapsto$ Open water period}

Figure 4B. Hydrographs for Clear Creek near Coralville showing baseline daily mean discharge and daily mean discharge estimated by analytical methods. 
records was significantly different $(p<.025)$ than the baseline discharge record, although two were marginal (table 8). The three hydrographers' streamflow records were significantly different $(\mathrm{p}<.025)$ from each other for two of the three compilations (table 9).

The hydrographic-and-climatic-comparison method requires knowledge of ice-affected streamflow computation techniques. All other materials or data
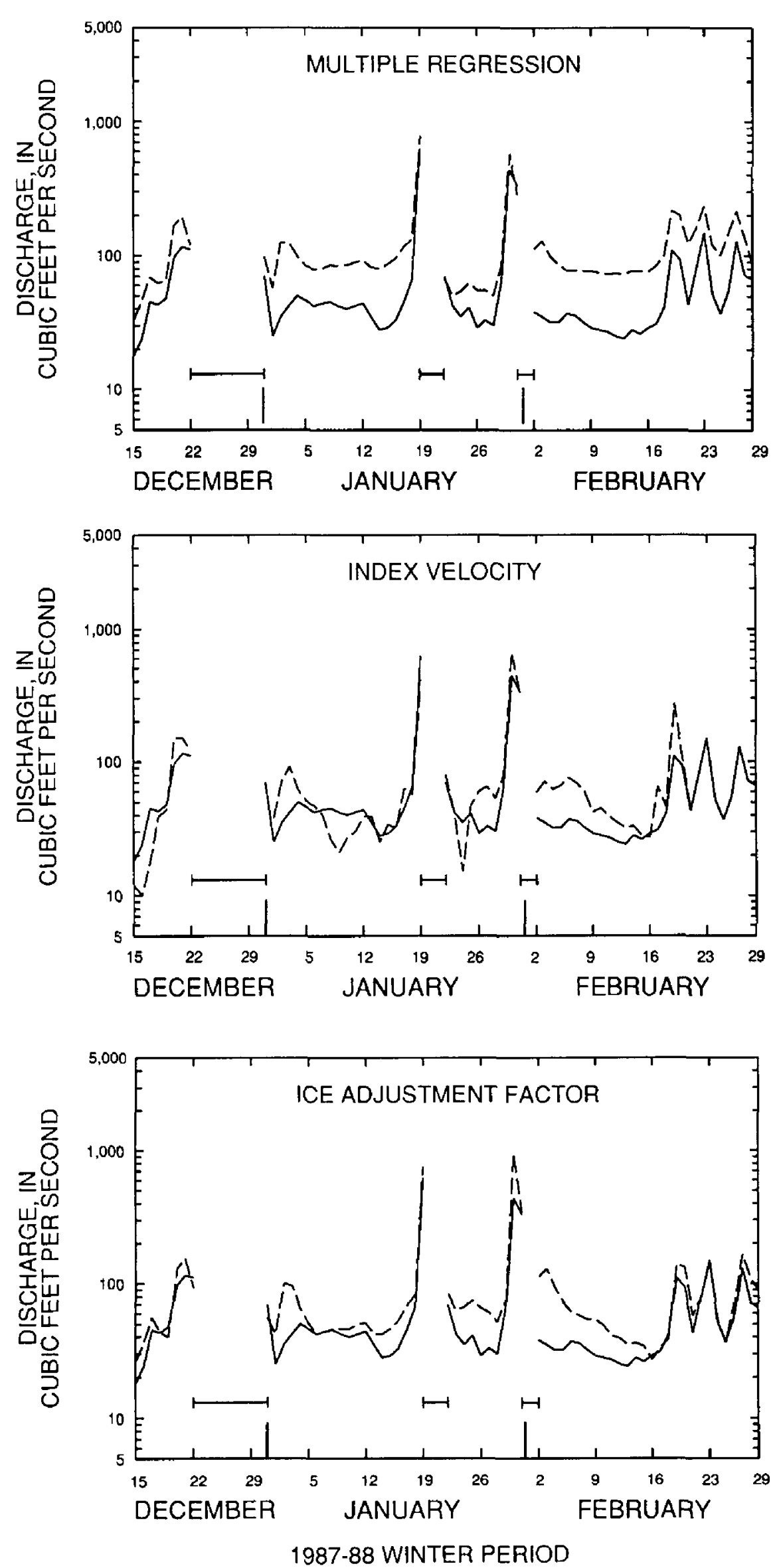

needed for method application are available for the existing streamflow-gaging network. The method is dependent on individual judgement and experience in determining the relative importance of discharge measurements, meteorological information, indicated openwater discharges, and information from hydrographic comparison. The method is suitable for application under all ice conditions. The method is not adaptable
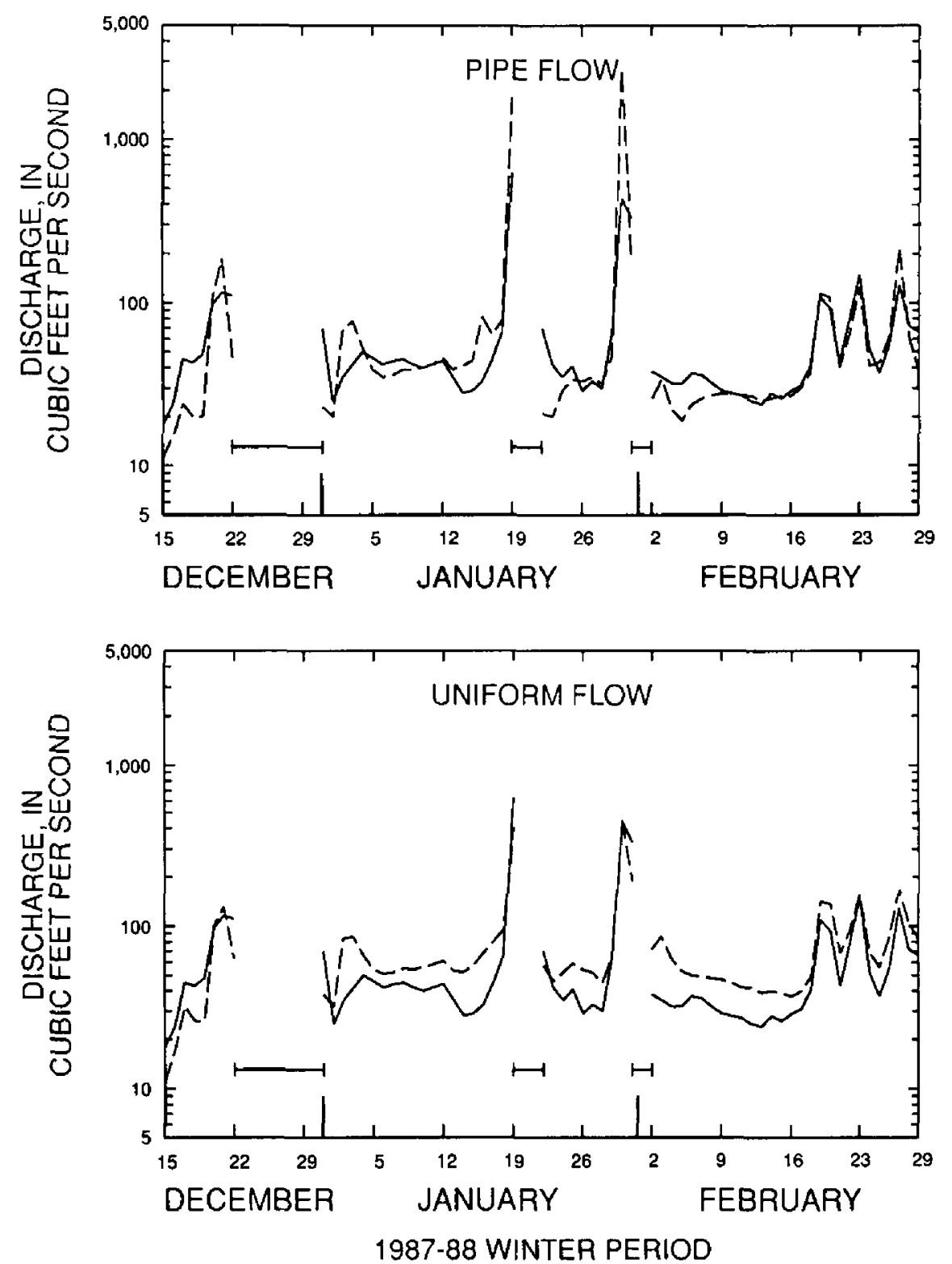

EXPLANATION

Baseline record

- - Estimated discharge

$\longmapsto$ Open water period

Figure 4C. Hydrographs for Clear Creek near Coralville showing baseline daily mean discharge and daily mean discharge estimated by analytical methods. 
to automated data processing because it depends on individual judgement rather than a systematic computation. The method is applicable to the existing U.S. Geological Survey streamflow-gaging network.

The hydrographic-and-climatic-comparison method produced more reliable results compared to the other subjective methods, and results comparable with the best analytical methods. This is the only method the test hydrographers were experienced with prior to this study. Experience may have been a factor in the results of this study.

\section{ANALYTICAL METHODS}

\section{Prorated Discharge}

The prorated discharge method overestimated the baseline mean for the ice-affected periods for all three record compilations. The average percent error between the method mean and the baseline mean for each stream is shown in table 5 . The mean daily relative error ranged from 0.18 to 2.5 (table 6 ). The standard deviation of the daily relative errors ranged from 0.28 to 4.54 for the three compilations (table 6). The relative error of the daily discharge values indicated that 8 percent of the daily values were excellent ( $0-5$ percent error); 18 percent were good to excellent ( $0-10$ percent error); and 28 percent were fair to excellent $(0-15$ percent error). Thirty percent of the daily values had relative errors between 15 and 50 percent, and 42 percent had relative errors greater than 50 percent (table 7). One of the three discharge records was significantly different $(\mathrm{p}<.025)$ than the baseline discharge record (table 8).

The prorated discharge method does not require any special knowledge or skill except for simple linear interpolation. All other materials or data needed for method application are available for the existing streamflow-gaging network. The method can be applied under all ice conditions. This method is adaptable to automated data processing because it is based on linear interpolation of measured discharge. The method could be applied to the existing U.S. Geological Survey streamflow-gaging network. Because the prorated discharge method does not use relevant data that is collected at most streamflow-gaging stations, the results probably will not be as reliable as the results of methods that use more stream parameters.

The prorated discharge method was included in the study to compare the results of the other methods with the results of linear discharge proration. The prorated discharge method is not recommended for compiling ice-affected streamflow record.

\section{Discharge Ratio}

The discharge ratio method underestimated the baseline mean for the ice-affected periods for one record compilation and overestimated the baseline mean for two compilations (three streams). The average percent error between the method mean and the baseline mean for each stream is shown in table 5 . The mean daily relative error ranged from -0.02 to 0.71 (table 6 ). The standard deviation of the daily relative errors ranged from 0.27 to 0.58 for the three compilations (table 6). The relative error of the daily discharge values indicated that 9 percent of the daily values were excellent $(0-5$ percent error); 18 percent were good to excellent $(0-10$ percent error); and 30 percent were fair to excellent $(0-$ 15 percent error). Thirty-seven percent of the daily values had relative errors between 15 and 50 percent, and 33 percent had relative errors greater than 50 percent (table 7). One of the three discharge records was significantly different $(\mathrm{p}<.025)$ than the baseline discharge record (table 8).

The discharge ratio method requires only a general knowledge of ice-affected streamflow computation techniques. The method uses a discharge ratio curve developed each year. All other materials or data needed for method application are available for the existing streamflow-gaging network. The method is based on the assumption that the ratio of measured to rated discharge is representative for the periods between discharge measurements. The method can be used for all ice conditions; however, if the discharge ratio is computed for one ice condition and used to define discharge during another condition, the results may not be reliable. The method is adaptable to automated data processing. The discharge ratio line could be computed using automated data processing because the discharge ratio line is developed by linear interpolation. Linear interpolation of the discharge ratio line may cause obviously anomalous results during changing ice conditions. This method could be used for ice computations within the existing U.S. Geological Survey streamflow-gaging network.

The discharge ratio method was included in the study to compare the results of an analytical solution of this method with a subjective solution. Collection of discharge measurements for optimum definition of the discharge ratio line probably would improve the method results. The subjective solution produced more reliable results than the analytical solution, therefore the analytical discharge ratio method is not recommended for compiling ice-affected streamflow record.

\section{Backwater Shift}

The backwater shift method overestimated the baseline mean for all three record compilations. The average percent error between the method mean and the baseline mean for each stream is shown in table 5 . The mean daily relative error ranged from 0.08 to 0.78 (table 6). The standard deviation of the daily relative 

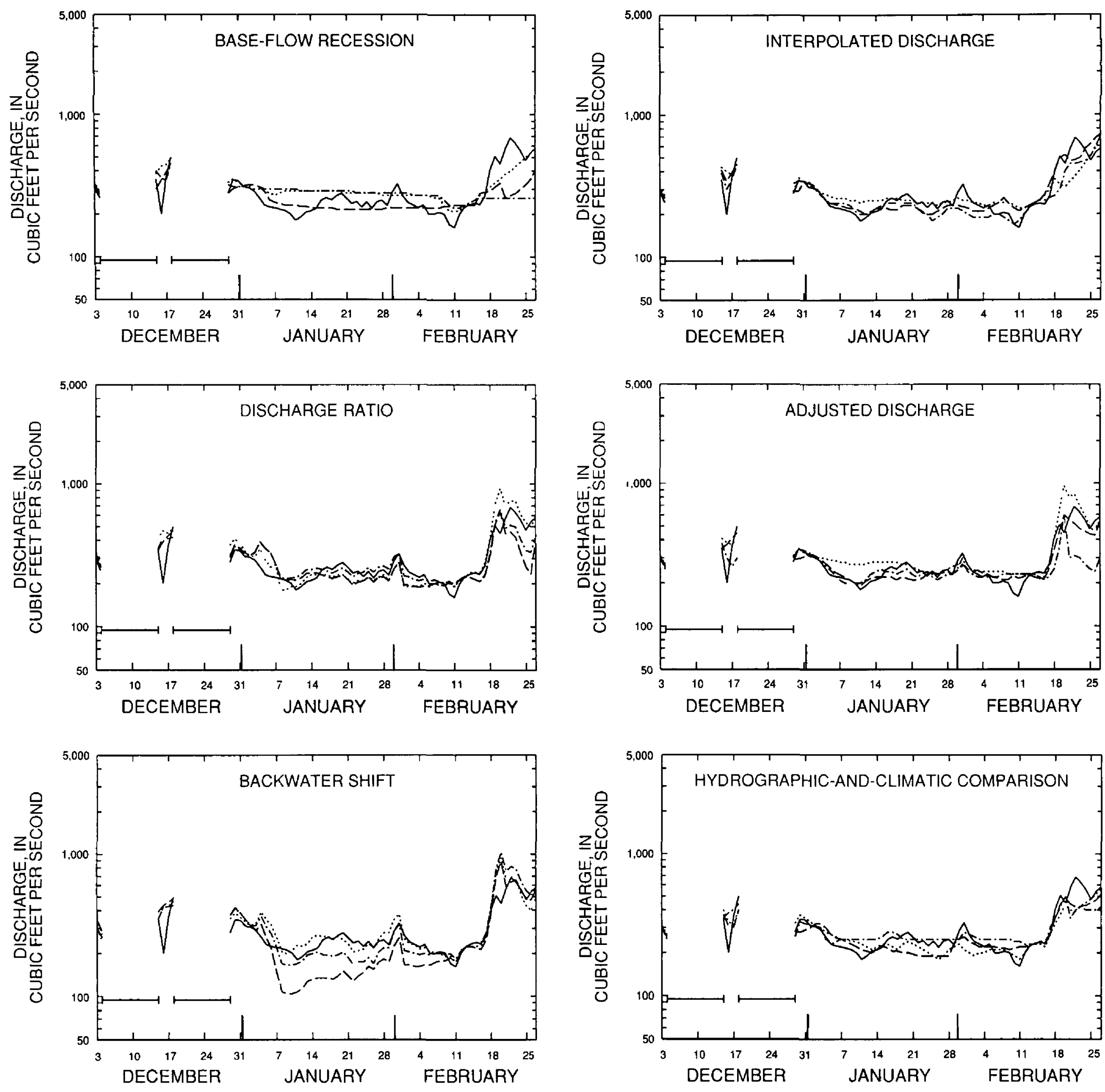

1987-88 WINTER PERIOD

1987-88 WINTER PERIOD

EXPLANATION

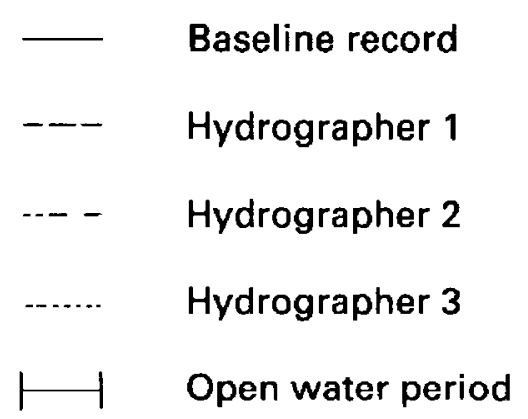

Figure 5A. Hydrographs for the Des Moines River at Fort Dodge showing baseline daily mean discharge and daily mean discharge estimated by subjective methods. 
errors ranged from 0.29 to 0.72 for the three compilations (table 6). The relative error of the daily discharge values indicated that 13 percent of the daily values were excellent ( $0-5$ percent error); 23 percent were good to excellent ( $0 \rightarrow 10$ percent error); and 35 percent were fair to excellent (0-15 percent error). Thirty-four percent of the daily values had relative errors between 15 and 50 percent, and 31 percent had relative errors greater than 50 percent (table 7). One of the three discharge records was significantly different $(p<.025)$ than the baseline discharge record (table 8 ).

The backwater shift method requires only a general knowledge of ice-affected streamflow computation
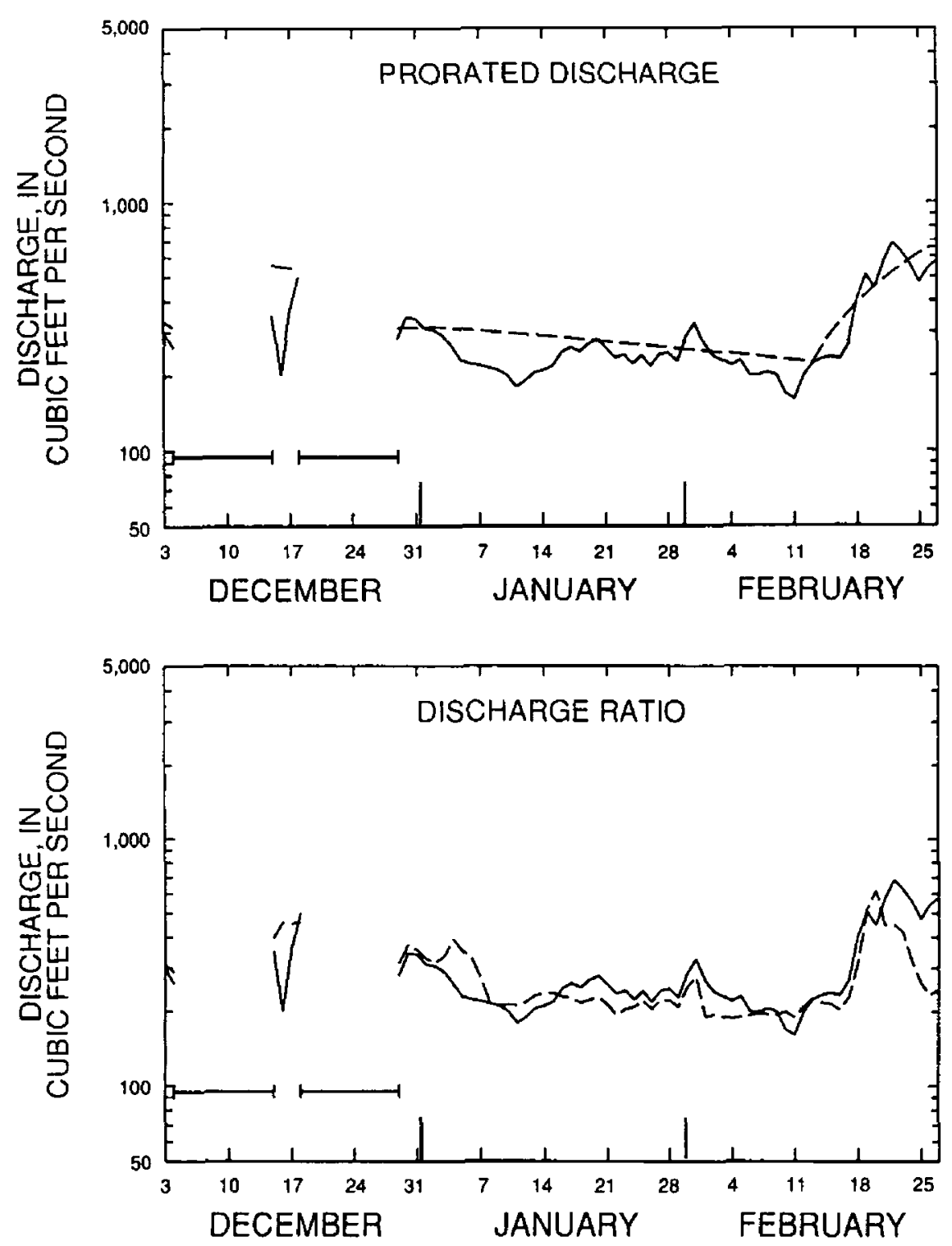

1987-88 WINTER PERIOD techniques. The method requires drawing a backwater shift curve for ice-affected periods. All other materials or data needed for method application are available for the existing streamflow-gaging network. The method is based on the assumption that the stream backwater defined by discharge measurements is representative for the periods between measurements. This is the basis for the use of open-water shift application, but the variability of backwater from ice generally is greater during iceaffected periods. The method can be used for all ice conditions; however, if a backwater shift is computed for one ice condition and used to define discharge during another condition, the results may not be reli-
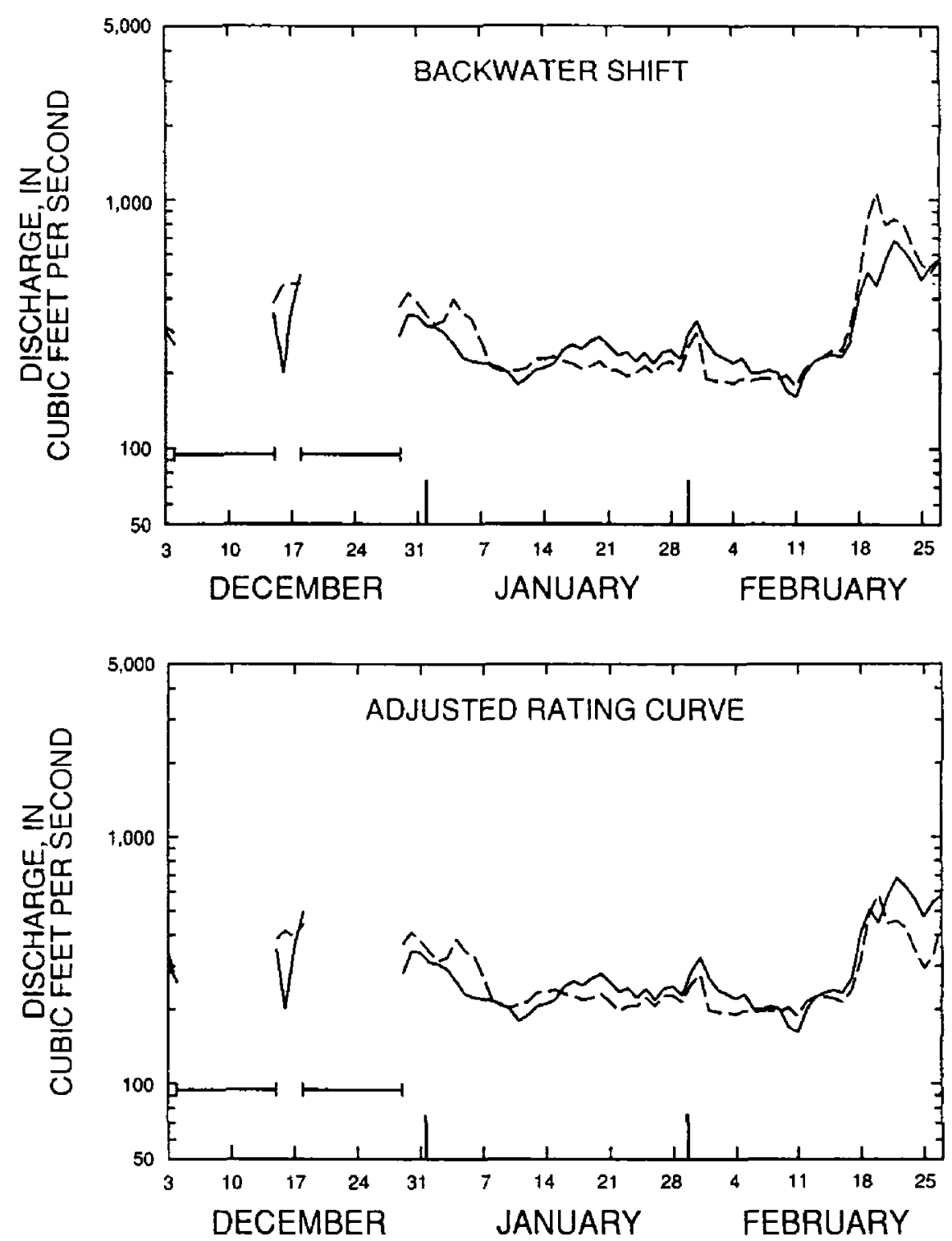

1987-88 WINTER PERIOD

\section{EXPLANATION}

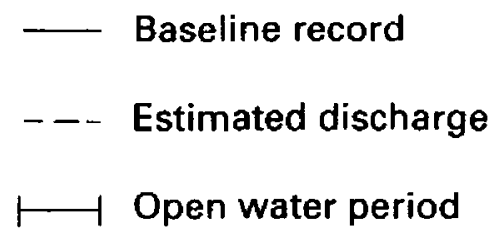

Figure 5B. Hydrographs for the Des Moines River at Fort Dodge showing baseline daily mean discharge and daily mean discharge estimated by analytical methods. 
able. Linear interpolation of the backwater curve may cause obviously anomalous results during changing ice conditions. The method is adaptable to automated data processing. The backwater curve could be computed using automated data processing because the backwater curveis determined by linear interpolation. The method could be used for ice computations within the existing U.S. Geological Survey streamflow-gaging network.

The backwater shift method was included in the test to compare the results of an analytical solution of this method with a subjective solution. The subjective solution produced more reliable results than the analytical solution, therefore the analytical backwater shift method is not recommended for compiling ice-affected streamflow record.

\section{Stage Fall}

The stage-fall method overestimated the baseline mean for the ice affected periods for one record compilation and underestimated the mean for the other compilation. The average percent error between the method mean and the baseline mean for each stream is shown
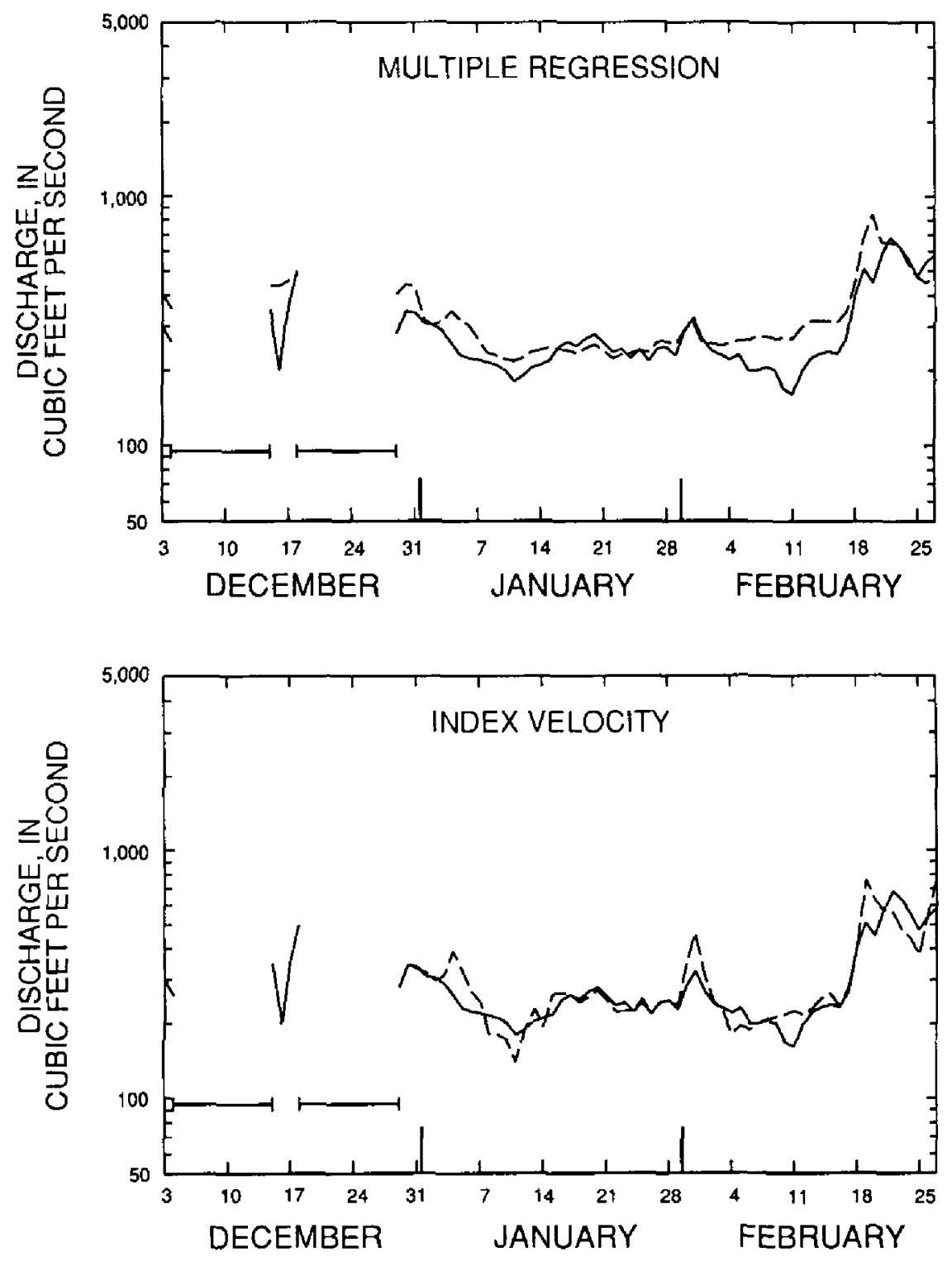

1987-88 WINTER PERIOD in table 5. The mean daily relative errors were 0.07 and 1.63 (table 6). The standard deviations of the daily relative errors were 0.34 and 1.26 (table 6 ). The relative error of the daily discharge values indicated that 8 percent of the daily values were excellent $(0-5$ percent error); 12 percent were good to excellent $(0-10$ percent error); and 16 percent were fair to excellent (0-15 percent error). Thirty-two percent of the daily values had relative errors between 15 and 50 percent, and 52 percent had relative errors greater than 50 percent (table $7)$. Neither of the two discharge records were significantly different $(\mathrm{p}<.025)$ from the baseline streamflow record (table 8).

The stage fall method requires a general knowledge of slope stations and regression analysis. Determination of the least-backwater rating and subsequent least-fall curve requires some hydrologic judgement. Imperfectly defined curves reduced the reliability of the method for the sites examined. The method is empirical; however, it uses slope station concepts, which are widely accepted. The method appears to be applicable to all ice conditions, but would be most suitable for complete ice

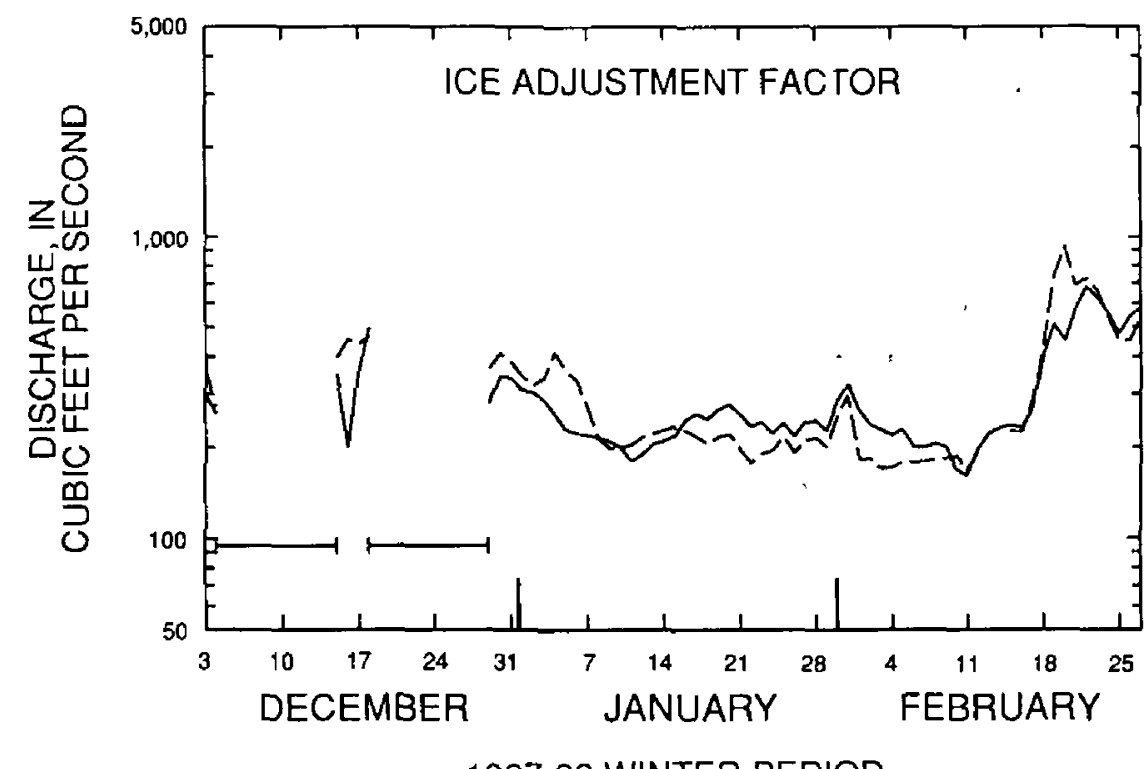

1987-88 WINTER PERIOD

EXPLANATION

Baseline record

-_- Estimated discharge

$\longmapsto$ Open water period

Figure 5C. Hydrographs for the Des Moines River at Fort Dodge showing baseline daily mean discharge and daily mean discharge estimated by analytical methods. 
cover. The method is easily adapted to computers either through regression relations or table interpolation, and the resulting discharge values could be computed for the time unit used to record gage height for the streamflow-gaging station. Implementation throughout the U.S. Geological Survey streamflow-gaging network would require auxiliary gage height data, and increased measurement frequency for at least two winters to define the necessary curves. The auxiliary gage height data would require either continuous gage-height monitoring or the use of observers to obtain daily gageheight values.

The results of the test of the stage -fall method are not directly comparable to the results for the other methods because complete record is not available for all three stations, and the frequent measurement data collected during this study was used for the regression analyses. The method worked well for Clear Creek, but produced poor results for the Floyd River. The location of the auxiliary gage for the Floyd River could account for the poor results. The method requires an auxiliary gage to establish the fall in the control section; if the auxiliary gage is outside of the control section, the results will be unreliable. The stage-fall method is not recommended for compiling ice-affected streamflow record.

\section{Adjusted Rating Curve}

The adjusted rating curve method overestimated the baseline mean for the ice affected periods for one record compilation and underestimated the mean for the other two compilations. The average percent error between the method mean and the baseline mean for each stream is shown in table 5 . The mean daily relative error ranged from -0.10 to 0.40 (table 6 ). The standard deviation of the daily relative errors ranged from 0.23 to 0.54 (table 6 ). The relative error of the daily discharge values indicated that 14 percent of the daily values were excellent ( $0-5$ percent error); 28 percent were good to excellent ( $0-10$ percent error); and 42 percent were fair to excellent ( $0-15$ percent error). Forty percent of the daily values had relative errors between 15 and 50 percent, and 18 percent had relative errors greater than 50 percent (table 7). One of the three discharge records was significantly different $(\mathrm{p}<.025)$ from the baseline streamflow record (table 8).

The adjusted rating curve method requires a general knowledge of ice computation techniques, open channel hydraulics, and familiarity with vertical velocity profiles and curve fitting techniques. Determination of the ice and bed roughness requires a basic knowledge of hydraulics and curve fitting techniques. The estimation of the roughness ratio and the proration of the roughness ratio between measurements reduces the reliability of the method. Because the method uses a roughness ratio to compute discharge, it is probably only valid for a complete surface ice cover. The method is easily adapted to automated data processing and the resulting discharge values could be computed for the time unit used to record gage height for the streamflow-gaging station. Implementation throughout the U. S. Geological Survey streamflow-gaging network would require that vertical velocity profiles be obtained for at least 3 vertical locations during each ice-affected discharge measurement.

The adjusted rating curve method produced reasonable results, although several methods were better for all three streams. This method shows that accounting for the roughness of the ice is an improvement over the backwater shift (analytical) method. The method could be improved through a better understanding of the changes in shift and ice roughness over time. The adjusted rating curve method is recommended for further study for use in the U.S. Geological Survey streamflow-gaging network.

\section{Conductance Correlation}

The conductance correlation method overestimated the baseline mean for the ice-affected periods for both record compilations. The average percent error between the method mean and the baseline mean for each compilation is shown in table 5 . The mean daily relative errors were 0.02 and 1.85 (table 6). The standard deviations of the daily relative errors were 1.14 and 2.81 (table 6). The relative error of the daily discharge values indicated that less than one percent of the daily values were excellent ( $0-5$ percent error); 3 percent were good to excellent ( $0-10$ percent error); and 4 percent were fair to excellent ( $0-15$ percent error). Twenty-one percent of the daily values had relative errors between 15 and 50 percent, and 75 percent had relative errors greater than 50 percent (table 7 ). One of the two discharge records was significantly different $(\mathrm{p}<.025)$ from the baseline streamflow record (table 8 ).

The conductance correlation method requires knowledge of basic regression techniques. The regression relation would require periodic update. The reliability of the method is a function of the estimated regression equation. For the three sites considered, the regression results were variable (table 3 ). One site failed to produce a statistically significant regression, therefore data for this station was not compiled. The method is based on a statistical relation between discharge and stream conductance. Although the form of the regression relation may be site-specific, the general concept should be widely applicable to different ice conditions. The method is adaptable to automated data processing because it uses an equation. Implementation of the conductance correlation method throughout the U.S. 

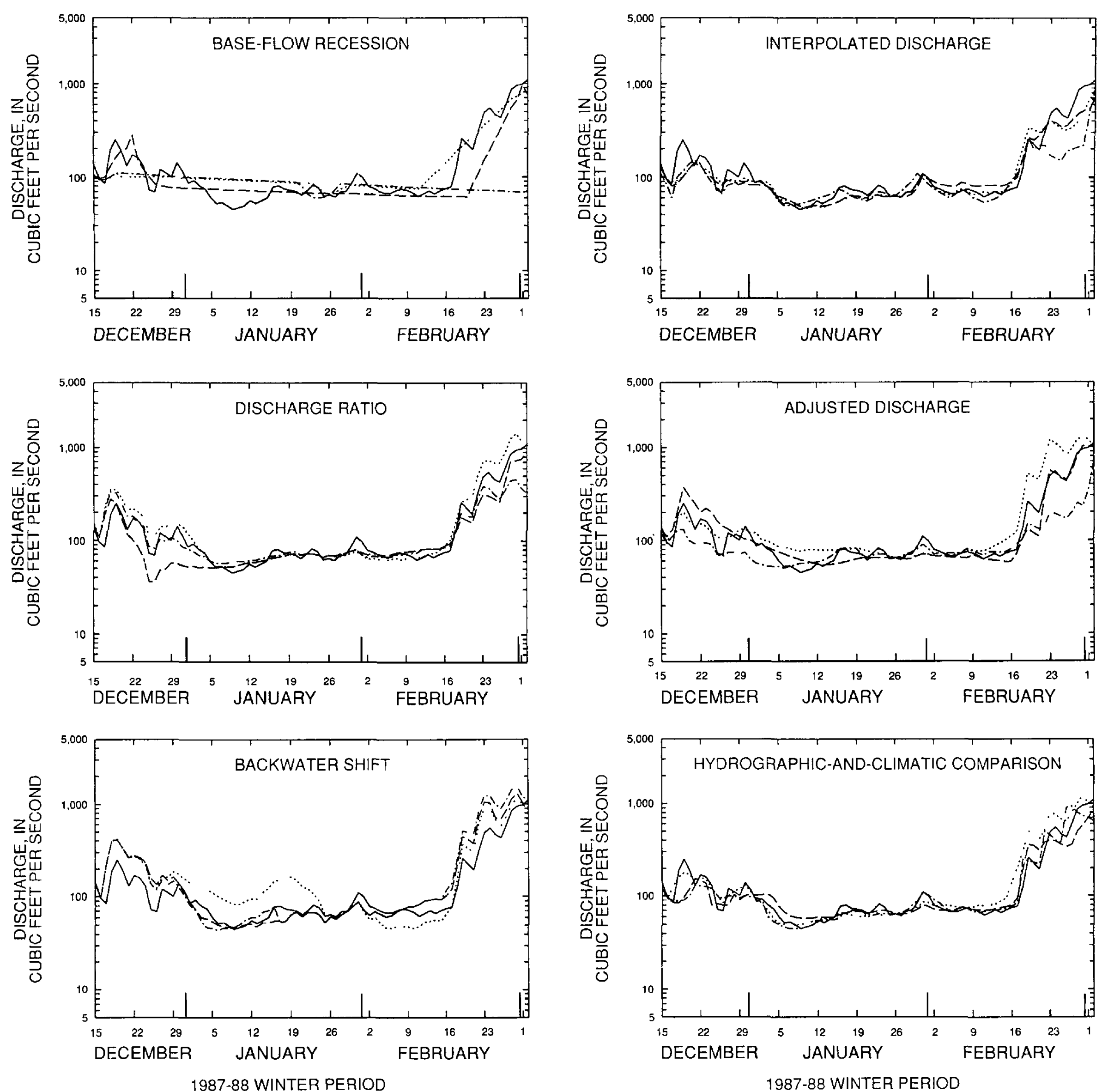

\section{EXPLANATION}

\section{Baseline record}

-_- Hydrographer 1

-.-- Hydrographer 2

-..- Hydrographer 3

Figure 6A. Hydrographs for the Floyd River at James showing baseline daily mean discharge and daily mean discharge estimated by subjective methods. 
Geological Survey network would require continuous specific conductance monitoring or the use of observers to obtain daily conductance values.

Although the conductance correlation method performed poorly, it produced reasonable discharge values during higher flows for Clear Creek (fig. 4). At lower flows the regression relation is not sufficiently sensitive to accurately reflect small changes in discharge. However, the method has some merit in reproducing higher
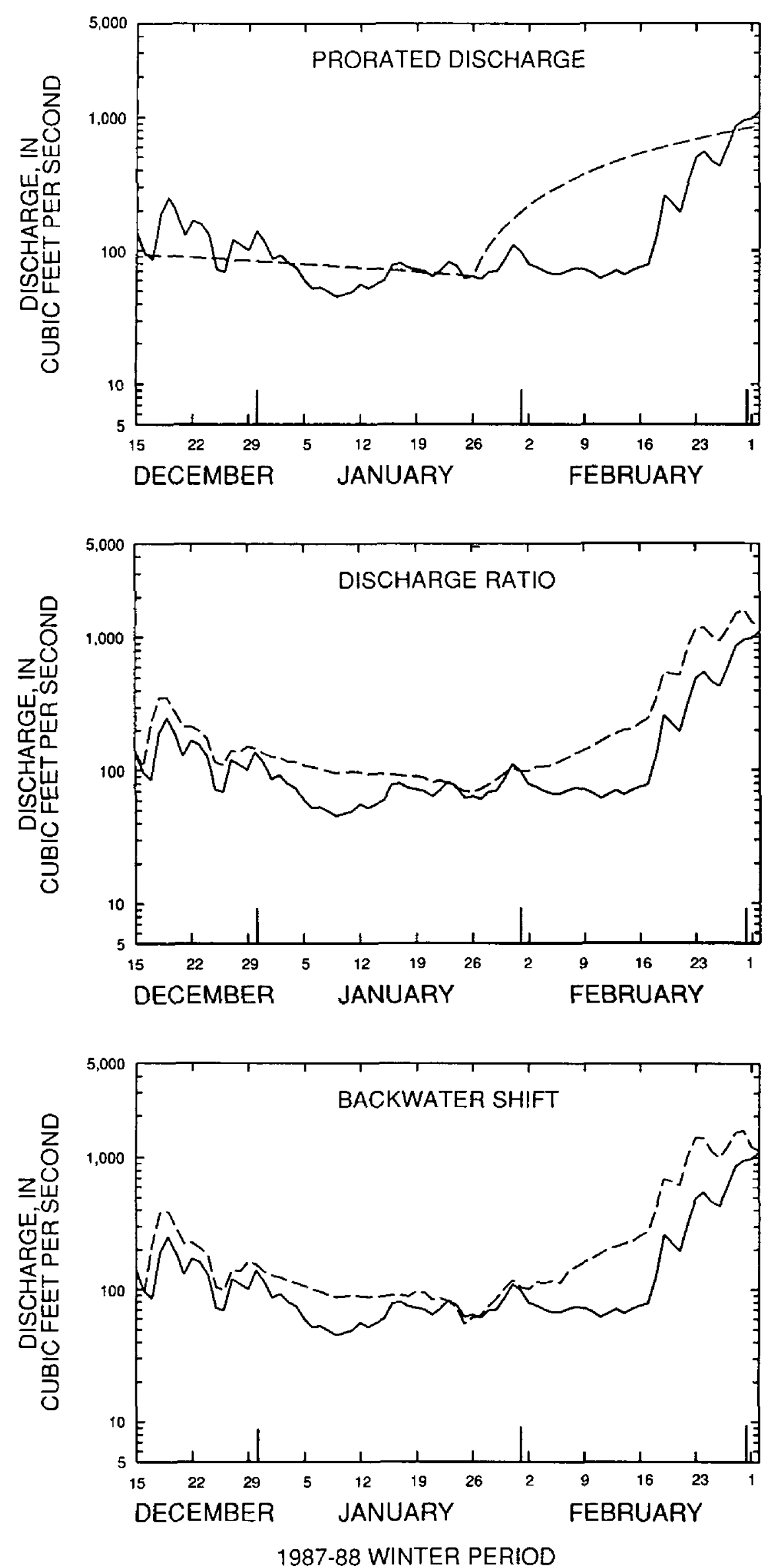

flows, and perhaps could be used in conjunction with another method. Use of a method to scale the data to the 6-week discharge measurements would improve the accuracy of the conductance correlation method (Melcher, 1988)

\section{Multiple Regression}

The multiple regression method overestimated the baseline mean for the ice-affected periods for all three
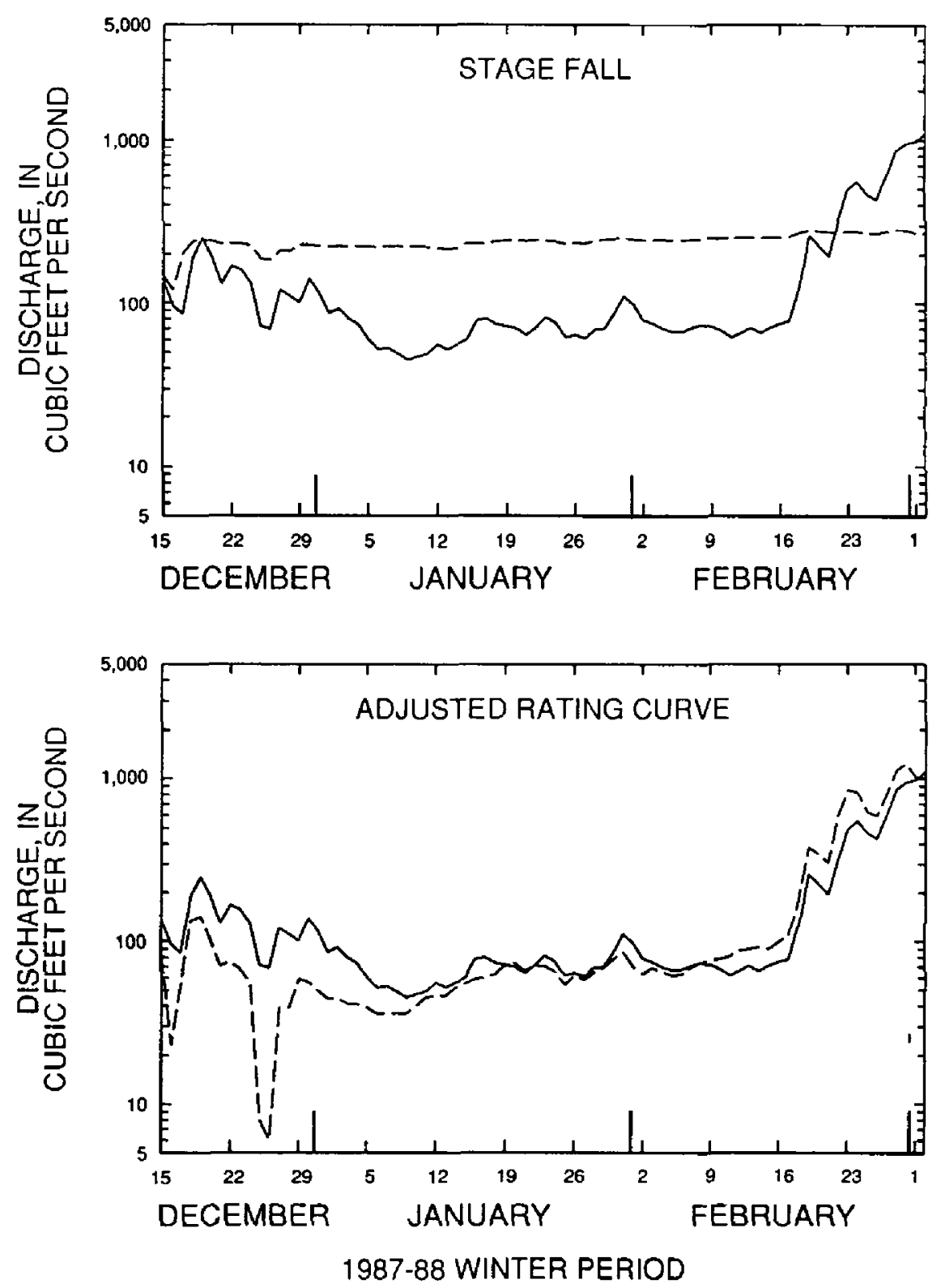

EXPLANATION

Baseline record

Estimated discharge

Figure 6B. Hydrographs for the Floyd River at James showing baseline daily mean discharge and daily mean discharge estimated by analytical methods. 
record compilations. The average percent difference between the method mean and the baseline mean for each stream is shown in table 5 . The mean daily relative error ranged from 0.18 to 1.73 , with a mean of 1.02 (table 6). The standard deviation of the daily relative errors ranged from 0.24 to 1.00 , with a mean of 0.63 (table 6). The relative error of the daily discharge values indicated that 7 percent of the daily values were excellent $(0-5$ percent error); 14 percent were good to excel-
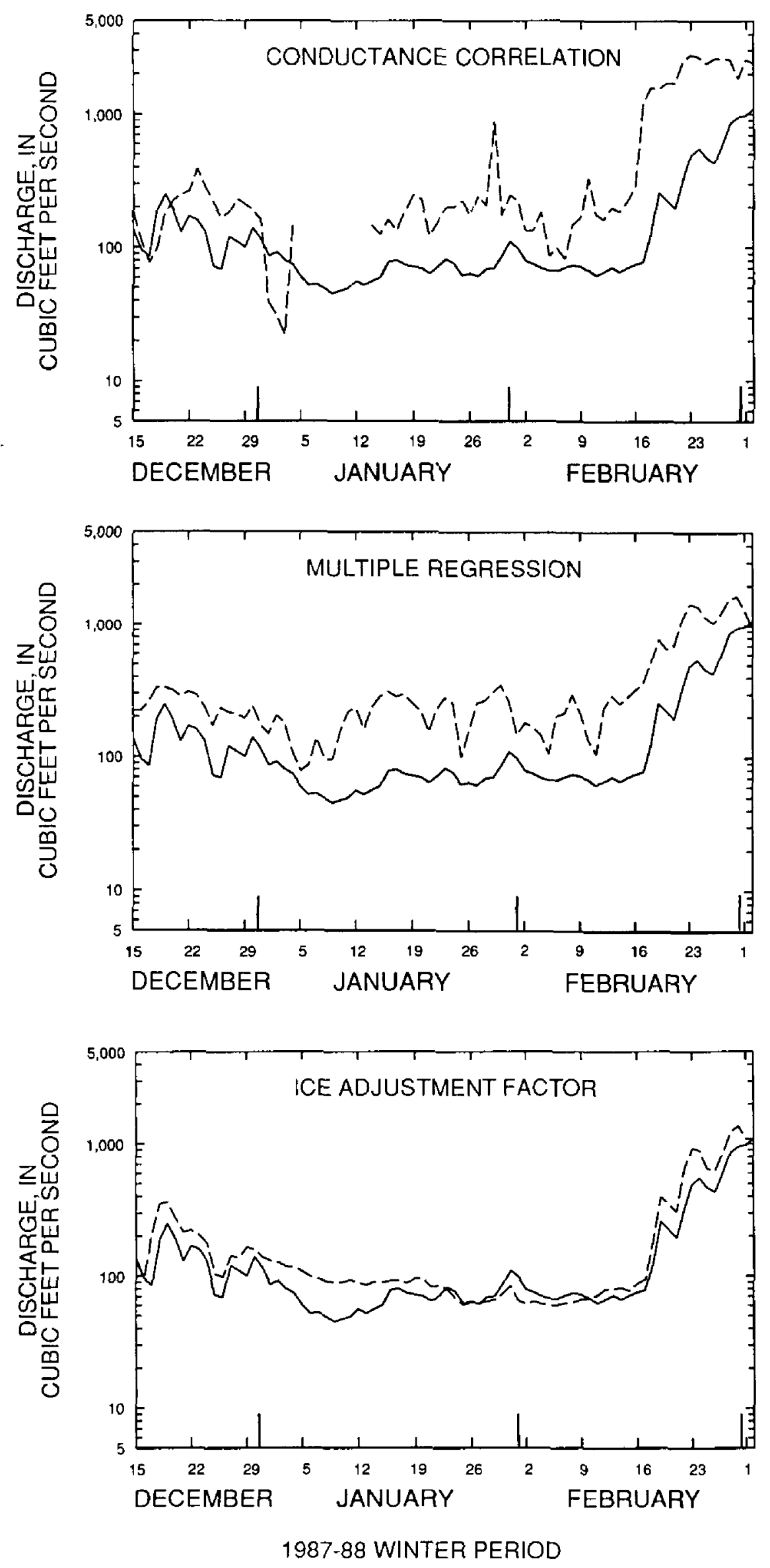

lent (0-10 percent error); and 18 percent were fair to excellent $(0-15$ percent error). Twenty percent of the daily values had relative errors between 15 and 50 percent, and 62 percent had relative errors greater than 50 percent (table 7). All three of the discharge records were significantly different $(\mathrm{p}<.025)$ from the baseline streamflow record (table 8 ).

The multiple regression method requires knowledge of advanced regression techniques. The method
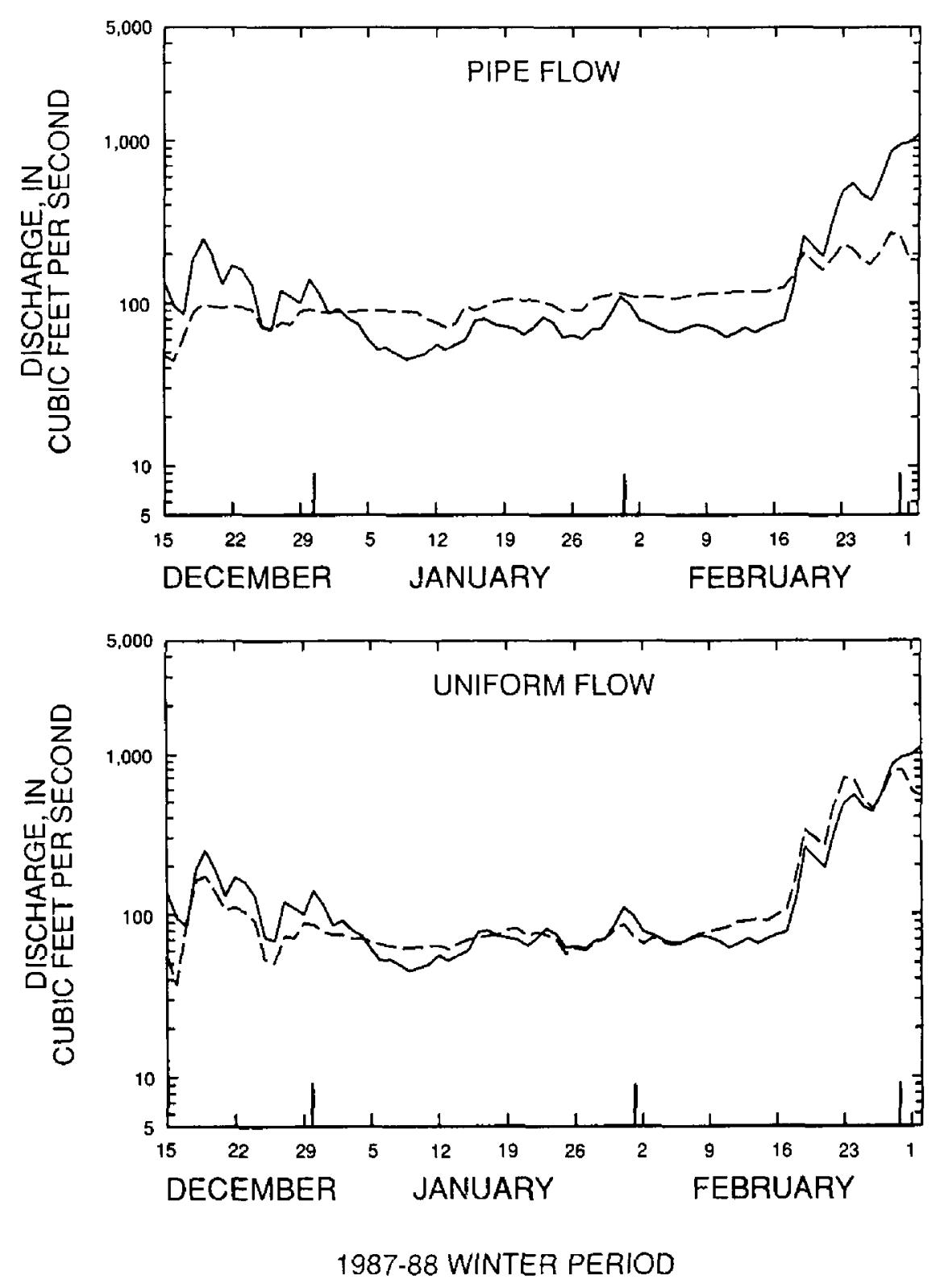

\section{EXPLANATION}

Baseline record

Estimated discharge

Figure 6C. Hydrographs for the Floyd River at James showing baseline daily mean discharge and daily mean discharge estimated by analytical methods. 
is based on a statistical relation between the dependent and independent variables. The accuracy of the method depends on the development of an accurate regression equation. The results of the regression analyses for the three streams were variable (table 4 ). The method would only be applicable to the ice conditions that were present during the discharge measurements used to establish the regression relations. Because the method uses an equation, the results are reproducible and the method is adaptable to automated data processing. Implementation throughout the U.S. Geological Survey network would require the appropriate climatological data for each site and compiled data for the correlated stations.

The application of the multiple regression method made no attempt to incorporate the information from the 6-week discharge measurements into the estimation process. The method generally reproduced the shape of

Table 8.-Significance levels for the difference between estimated discharge for each method and the baseline discharge

\begin{tabular}{|c|c|c|c|}
\hline \multirow[b]{2}{*}{ Method $^{1}$} & \multicolumn{3}{|c|}{ Significance level ${ }^{2}$} \\
\hline & Clear Creek & Des Moines River & Floyd River \\
\hline & \multicolumn{3}{|c|}{ Subjective methods } \\
\hline Base-flow recession (1) & 0.565 & 0.187 & 0.014 \\
\hline Base-flow recession (2) & .120 & .307 & .682 \\
\hline Base-flow recession (3) & .831 & .051 & .458 \\
\hline Discharge ratio (1) & .052 & .160 & .057 \\
\hline Discharge ratio (2) & .139 & .522 & .723 \\
\hline Discharge ratio (3) & .007 & .475 & .156 \\
\hline Backwater shift (1) & .001 & .014 & .349 \\
\hline Backwater shift (2) & .007 & .941 & .239 \\
\hline Backwater shift (3) & .003 & .115 & .036 \\
\hline Interpolated discharge (1) & .228 & .897 & .433 \\
\hline Interpolated discharge (2) & $<.001$ & .078 & .007 \\
\hline Interpolated discharge (3) & .146 & .146 & .152 \\
\hline Adjusted discharge (1) & .070 & .206 & .885 \\
\hline Adjusted discharge (2) & .362 & .163 & .004 \\
\hline Adjusted discharge (3) & .281 & .006 & .141 \\
\hline Hydrographic-and-climatic comparison (1) & .051 & .058 & .512 \\
\hline Hydrographic-and-climatic comparison (2) & .883 & .451 & .083 \\
\hline \multirow[t]{2}{*}{ Hydrographic-and-climatic comparison (3) } & .025 & .167 & .525 \\
\hline & \multicolumn{3}{|c|}{ Analytical methods } \\
\hline Prorated discharge & .152 & .006 & .255 \\
\hline Discharge ratio & .066 & .312 & .018 \\
\hline Backwater shift & .080 & .494 & .024 \\
\hline Stage fall & .897 & - & .106 \\
\hline Adjusted rating curve & .003 & .308 & .659 \\
\hline Conductance correlation & .605 & - & .009 \\
\hline Multiple regression & $<.001$ & .006 & .001 \\
\hline Index velocity & .057 & .364 & - \\
\hline Ice adjustment factor & $<.001$ & .965 & .040 \\
\hline Pipe flow & .299 & - & .944 \\
\hline Uniform flow & .001 & - & .878 \\
\hline
\end{tabular}

${ }^{1}$ The number in parentheses indicates the hydrographer who compiled the streamflow record.

${ }^{2}$ Significance level of the modified Wilcoxon test. Methods found to be statistically different from the baseline data at the 5 percent level appear in bold print. 
the hydrograph, but tended to consistently over or underestimate the discharge (figs. 4-6). Use of a method to scale the data to the 6-week discharge measurements would improve the accuracy of the multiple regression method (Melcher, 1988). Continued use of the method would result in greater experience in determining relevant variables for the regression equations, and could improve the accuracy of the method. The accuracy could be further improved by increasing the discharge measurement frequency at the correlated stations. Further study of the multiple regression method is warranted.

\section{Index Velocity}

The index velocity method overestimated the baseline mean for the ice-affected periods for both record compilations. The average percent error between the method mean and the baseline mean for each stream is shown in table 5 . The mean daily relative errors were 0.04 and 0.28 (table 6). The standard deviations of the daily relative errors were 0.51 and 0.18 (table 6). The relative error of the daily discharge values indicated that 26 percent of the daily values were excellent ( $0-5$ percent error); 39 percent were good to excellent ( $0-10$ percent error); and 51 percent were fair to excellent ( $0-15$ percent error). Thirty-two percent of the daily values had relative errors between 15 and 50 percent, and 17 percent had relative errors greater than 50 percent (table 7). Neither of the two discharge records were significantly different $(\mathrm{p}<.025)$ than the baseline discharge record (table 8).

The index velocity method requires a general knowledge of ice computation techniques, the use and maintenance of velocity monitoring equipment, and an understanding of the basic hydraulic principles of open-channel flow. The method is based on the principle that discharge is the product of mean velocity and cross-sectional area. The variation of the spatial distribution of velocity during periods of ice effect causes the relation between measured velocity and mean velocity to vary. The method can be used for all ice conditions; however, in this study the most reliable velocity data was obtained during complete ice cover. The method is adaptable to automated data processing and the resulting discharge values could be computed for the time unit used to record gage height and velocity for the streamflow-gaging station. Velocity data is difficult to obtain during anchor-ice conditions or for streams with a mean depth less than $1 \mathrm{ft}$. The use of this method throughout the existing U.S. Geological Survey network would require a large capital investment to purchase velocity monitoring equipment. Future advances in velocity monitoring equipment and technology may make this method more suitable for widespread use.
The results of the test of the index velocity method are not directly comparable to the results for the other methods because complete record is not available for the Floyd River at James, and because malfunctioning equipment resulted in some missing record for the other two sites (figs. 4 and 5). The results of the study indicate that the index velocity method can produce satisfactory results. Many of the field and office procedures for applying this method were developed for this study. Repetitive use of this method probably would result in improvements in these procedures, make the method easier to use, and may improve the reliability of the results. Improvements in method accuracy probably could be obtained as field personnel became more experienced with the velocity monitoring equipment. An improvement in the velocity record may also be obtained by using equipment that monitors an integrated stream velocity. The index velocity method may be an appropriate method for use where the need for accurate discharge estimates during ice-affected periods justifies the expense of collecting additional field data.

\section{Ice Adjustment Factor}

The ice adjustment factor method overestimated the baseline mean for the ice-affected periods for all three record compilations. The average percent error between the method mean and the baseline mean for each stream is shown in table 5 . The mean daily relative error ranged from 0.04 to 0.48 (table 6). The standard deviation of the daily relative errors ranged from 0.28 to 0.55 (table 6). The relative error of the daily discharge values indicated that 13 percent of the daily values were excellent ( $0-5$ percent error); 24 percent were good to excellent ( $0-10$ percent error); and 38 percent were fair to excellent ( $0-15$ percent error). Thirty-nine percent of the daily values had relative errors between 15 and 50 percent, and 23 percent had relative errors greater than 50 percent (table 7). One of the three discharge records was significantly different $(\mathrm{p}<.025)$ from the baseline streamflow record (table 8 ).

The ice adjustment factor method requires knowledge of open-channel hydraulics and general ice computation procedures. Proration of the float depth and ice adjustment factor reduces the reliability of the method. The method is based on a simplification of Manning's equation. The method was developed for periods of stable ice cover; thus application to other conditions could be unreliable. The method is easily adapted to automated data processing and the resulting discharge values could be computed for the time unit used to record gage height for the streamflow-gaging station. Implementation to the U.S. Geological Survey network would require hydraulic geometry tables before and after each winter, and a reasonable procedure 
Table 9.-Results from the Kruskal-Wallis one-way anaylsis of variance comparing the record compilations by the three hydrographers to the baseline record for each method $[<$, less than ]

\begin{tabular}{lccc}
\hline & \multicolumn{3}{c}{${\text { Significance level }(\mathbf{p})^{1}}^{1}$} \\
\cline { 2 - 4 } Method & Clear Creek & Des Moines River & Floyd River \\
\hline Base-flow recession & 0.071 & $<0.001$ & 0.001 \\
Discharge ratio & .520 & .040 & $<.001$ \\
Backwater shift & .264 & $<.001$ & .515 \\
Interpolated discharge & $<.001$ & .002 & .222 \\
Adjusted discharge & .001 & $<.001$ & $<.001$ \\
Hydrographic-and-climatic comparison & .138 & .008 & .013 \\
\hline
\end{tabular}

${ }^{1}$ Methods where the three hydrographers were found to be statistically different from each other at the 5 percent level $(\mathrm{p}<.025)$ appear in bold print.

for determining float depth and ice adjustment factor between measurements.

In general, the ice adjustment factor method should only be applied to conditions with a stable stagedischarge rating and stable hydraulic geometry characteristics. Many of the sites in the U.S. Geological Survey streamflow-gaging network do not have stable stagedischarge ratings. Failure of the method to accurately reproduce the streamflow records for this study can be attributed primarily to the instability of the sites chosen (H. Santeford, Michigan Tech. Univ., written commun.). The ice adjustment factor method may be appropriate for use where the need for accurate discharge estimates during ice-affected periods justifies the expense of the additional data tabulation, and for stations with stable stage-discharge ratings.

\section{Pipe Flow}

The pipe-flow method overestimated the baseline mean for the ice-affected periods for one record compilation and underestimated the mean for the other compilation. The average percent error between the method mean and the baseline mean for each stream is shown in table 5 . The mean daily relative errors were 0.07 and 0.13 (table 6 ). The standard deviations of the daily relative errors were 0.50 and 0.79 (table 6). The relative error of the daily discharge values indicated that 15 percent of the daily values were excellent $(0-5$ percent error); 27 percent were good to excellent ( $0-10$ percent error); and 37 percent were fair to excellent ( 0 15 percent error). Thirty-nine percent of the daily values had relative errors between 15 and 50 percent, and 24 percent had relative errors greater than 50 percent (table 7). Neither of the two discharge records were significantly different $(\mathrm{p}<.025)$ from the baseline streamflow record (table 8 ).
The pipe flow method requires knowledge of general hydraulic principles, regression analysis techniques and statistical judgement. The method is based on accepted hydraulic principles, although the regression relations result in an empirical component. Imperfect regression relations diminish the reliability of the method. Because of the pipe-flow analogy, the method is strictly applicable to complete ice-cover conditions, and would work best for stable conditions. This method is directly applicable to automated data processing because equations are used, and the resulting discharge values could be computed for the time unit used to record gage height for the streamflow-gaging station. Implementation throughout the U.S. Geological Survey streamflow-gaging network would require auxiliary gage height data and the development of the regression relations based upon one or two winters with increased measurement frequency. The auxiliary gage-height data would require either continuous monitoring or the use of observers to obtain daily gage-height values.

The results for the pipe flow method are not directly comparable to the results for the other methods because complete record is not available for all three stations, and the frequent measurement data collected during this study were used for the regression analyses. The method produced reasonable results for Clear Creek, yet performed poorly for the Floyd River. The location of the auxiliary gage for the Floyd River probably accounted for the poor results. The pipe flow method is not recommended for use in the U.S. Geological Survey streamflow-gaging network.

\section{Uniform Flow}

The uniform-flow method overestimated the baseline mean for the ice-affected periods for one record compilation and underestimated the mean for the 
other compilation. The average percent error between the method mean and the baseline mean for each stream is shown in table 5 . The mean daily relative errors were 0.01 and 0.35 (table 6). The standard deviations of the daily relative errors were 0.26 and 0.43 (table 6). The relative error of the daily discharge values indicated that 12 percent of the daily values were excellent ( $0-5$ percent error); 20 percent were good to excellent ( $0-10$ percent error); and 26 percent were fair to excellent $(0-15$ percent error). Fifty-six percent of the daily values had relative errors between 15 and 50 percent, and 18 percent had relative errors greater than 50 percent (table 7 ). One of the two discharge records was significantly different $(\mathrm{p}<.025)$ from the baseline streamflow record (table 8).

The uniform-flow method requires knowledge of open-channel hydraulics, vertical velocity profiles, and general curve fitting techniques. Several assumptions are required for the computation of roughness, and the proration of roughness and ice area between measurements reduces the reliability of the method. The method is based on Manning's equation. The method probably is suitable only for a surface ice-cover condition. The method is easily adapted to automated data processing and the resulting discharge values could be computed for the time unit used to record gage height for the streamflow-gaging station. Implementation throughout the U. S. Geological Survey streamflow-gaging network would require auxiliary gage-height data, and complete vertical velocity profiles for at least three locations during each ice-affected discharge measurement. The auxiliary gage-height data would require either continuous-stage monitoring or the use of observers to obtain once-daily gage-height values.

The results of the test of the uniform-flow method are not directly comparable to the results for the other methods because complete record is not available for all three stations. The method produced excellent results, demonstrating low daily error standard deviations for both sites, although Clear Creek showed a positive bias in the daily errors. The method could be improved through a better understanding of changes in ice roughness and ice thickness. Incorporation of a general ice accretion/ablation model (Yapa and Shen, 1986) would improve the ice area and roughness characterizations over time. The uniform-flow method may be appropriate for use where the need for accurate discharge estimates during ice-affected periods justifies the expense of collecting additional field data.

\section{NEEDS FOR FUTURE STUDY}

The characteristics of ice and ice-affected streamflow need further study. Several of the methods applied in this study could be improved by better characterization of the ice thickness and roughness over time. An improved understanding of ice accretion/ablation rates and its incorporation into these methods is required. For this study, uniform rates of ice accretion and ice roughness changes were assumed for application of several methods (adjusted rating curve, index velocity, ice adjustment factor, and uniform flow). If more were known about these changes, these corrections could be applied more realistically, and the results for these methods would be more reliable.

On the basis of frequent measurement data collected at the three stations during this study, discharge varied more than expected. A study to consider the meteorological and environmental factors affecting the variability of streamflow under an ice cover is warranted. The relative importance of these factors needs to be understood for reliable use of multiple regression to estimate ice-affected streamflow.

The frequent measurements at the three stations indicate that streamflow is reduced by $40-50$ percent during the initial freeze-up period. The conditions affecting the magnitude and duration of the streamflow reductions due to freeze up need to be better understood.

The frequent measurements made during this study indicate backwater conditions vary throughout the iceaffected periods. There is a need to better understand the nature of backwater from various ice conditions, the variation of backwater over time for more widespread conditions, and the factors that cause backwater from ice to vary. The reliability of the results of methods that are based on an estimate of backwater (backwater shift, adjusted rating curve) would be significantly improved if the processes affecting backwater from ice were better understood.

Rantz and others (1982) noted that the accuracy of ice-affected discharge estimates could be improved by using the discharge-ratio method to provide dischargeestimates and then verifying these estimates using the hydrographic and climatic comparison method. On the basis of the results of this study, the authors concur with this suggestion. The study results indicate that the discharge-ratio method can produce reasonable discharge estimates and would be a reliable method for making initial discharge estimates. Any anomalous or outlier data obtained from the application of the discharge-ratio method could be identified and corrected using the hydrographic-and-climaticcomparison method. The discharge estimates could be further refined by computing the backwater shifts for the daily discharge estimates and inspecting these shifts for reasonable continuity. This procedure could be applied to the U.S. Geological Survey network without obtaining any new field data and could be adapted to automated data processing techniques. The implemen- 
tation of this procedure probably would improve the consistency and accuracy of ice-affected streamflow estimates.

\section{SUMMARY AND CONCLUSIONS}

Ice affects the stage-discharge relation for some portion of the winter at more than one-half of the streamflow-gaging stations operated by the U.S. Geological Survey. Ice-affected discharge usually is estimated using a method that is dependent on the judgment of the hydrographer and is not adaptable to automated data processing. To improve the reliability of estimates of ice-affected streamflow and the efficiency of processing streamflow record, proposed and existing methods for estimating ice-affected discharge records were evaluated for possible use by the U.S. Geological Survey.

Seventeen methods used for computing ice-affected discharge records were identified by a written survey of U.S. Geological Survey field offices and by a literature search. The methods were classified into two general categories for evaluation. Methods that require judgement are categorized as subjective methods. Methods that are based on a systematic computation are categorized as analytical methods. The methods were evaluated by applying the methods to data collected at three stations in Iowa during the winter of 1987-88. A baseline data set was compiled by collecting data needed for application of the seventeen methods and making discharge measurements at 1- to 5-day intervals at the three stations. The discharge records for each method were compiled by simulating a normal 6-week field schedule. The subjective methods were independently applied by three hydrographers. The analytical methods were applied by the authors.

Each method was evaluated for subjective factors including method costs, technical soundness, applicability to various ice conditions, compatibility with automated data processing, and suitability for use in the existing U.S. Geological streamflow-gaging network. The methods were evaluated for accuracy by comparing the results for the seventeen methods with the baseline data set.

The discharge ratio and hydrographic-and-climaticcomparison methods generally produced more reliable results than the other subjective methods. Based on the results of this study, the base-flow recession method may not be appropriate for use in compiling ice-affected streamflow records. A comparison of the results for the interpolated discharge method, which does not use indicated open-water discharge, and the adjusted discharge method, which does not use hydrographic comparison, showed similar results, and indicated the following:
(1) The relative value of the use of hydrographic comparison and indicated open-water discharges are considered to be about equal.

(2) Comparing the results of the interpolated discharge, adjusted discharge, and hydrographic-andclimatic-comparison methods, the use of both indicated open-water discharges and hydrographic comparison improves the accuracy of ice-affected discharge estimates.

On the basis of a non-parametric analysis of variance, two methods (adjusted discharge and base-flow recession) showed significant differences in the records worked by the individual hydrographers. The hydrographic-and-climatic comparison and interpolated discharge methods each had a moderate degree of subjectivity, whereas the discharge ratio and backwater shift methods were the most consistent.

The index velocity, adjusted rating curve, and uniform flow methods generally produced more reliable results than the other analytical methods considered. The adjusted rating curve method was slightly more accurate at reproducing the mean discharge for the entire ice period, whereas the uniform flow and index velocity methods were slightly better at reproducing the daily discharges. The ice adjustment factor and discharge ratio methods worked reasonably well for the Des Moines River (the most stable of the three streams), and probably would provide reasonable results for situations with a stable geometry and stage-discharge rating. The analytical prorated discharge, discharge ratio, backwater shift, stage fall, and pipe flow methods are not recommended for use in compiling ice-affected streamflow record.

Based on the results of the evaluation for the three Iowa stations, the discharge ratio and hydrographicand-climatic-comparison methods were more accurate than the other subjective methods, and about as accurate as the best analytical method. The index-velocity method, the adjusted rating curve method, and the uniform flow method could potentially be used for streamflow-gaging stations where the need for accurate ice-affected discharge estimates justifies the expense of collecting additional field data. The use of these methods may not be appropriate for certain ice conditions. The ice adjustment factor method may be appropriate for use for stations with extremely stable stage-discharge ratings and measuring sections. Further research is needed to refine these methods. The discharge ratio method and multiple regression method may produce reliable estimates of streamflow for varying ice conditions using information obtained from the existing U.S. Geological Survey streamflow-gaging network. Improvements in the accuracy of the results of some of the methods may be obtained as users obtain more experience at method application. 


\section{REFERENCES CITED}

Alger, G.R. and Santeford, H.S., 1984, A procedure for calculating river flow rate under an ice cover, Proceedings, International Symposium on Ice, International Association of Hydraulic Research, Hamburg, West Germany, p. 389-398.

— 1987, Composite resistance to flow with an ice cover, Proceedings, National Conference on Hydraulic Engineering, American Society of Civil Engineers, Williamsburg, Va., p. 812-817.

Buchanan, T.J. and Somers, W.P., 1969, Discharge measurements at gaging stations: U.S. Geological Survey Techniques of Water-Resources Investigations, Book 3, Chapter A8, 65 p.

Calkins, D.J., Deck, D.S., and Martinson, C.R., 1980, Analysis of velocity profiles under ice in shallow streams, Proceedings, Workshop on Hydraulic Resistance of River Ice, National Water Research Institute, Burlington, Ontario, p. 94-111.

__ 1982, Resistance coefficients from velocity profiles in ice-covered shallow streams: Canadian Journal of Civil Engineering, v. 9, no. 2, p. 236-247.

Carey, K.L., 1967, Analytical approaches to computation of discharge of an ice-covered stream: U.S. Geological Survey Professional Paper 575-C, p.C200-C207.

Conover, W.J., 1971, Practical nonparametric statistics: John Wiley and Sons, New York, N.Y., 462 p.

Davar, K.S. and MacGougan, M., 1984, Analysis of river ice resistance from measured velocity profiles, Proceedings, International Symposium on lce, International Association of Hydraulic Research, Hamburg, West Germany, p. 349-358.

El Shaarawi, A.H. and Damsleth, E., 1988, Parametric and nonparametric tests for dependent data, Water Resources Bulletin, v. 24, no. 3, p. 513-519.

Fontaine, R.A., 1983, Uncertainties in records of annual mean discharge in Maine: U.S. Geological Survey Water-Resources Investigations Report 83-4025, $108 \mathrm{p}$.

Gogus, M. and Tatinclaux, J.C., 1980, Characteristics of flow below a rough floating cover, Proceedings, Workshop on Hydraulic Resistance of River Ice, National Water Research Institute, Burlington, Ontario, p. 122-141.

1981, Mean chacteristics of asymmetric flowsapplication to flow below ice jams: Canadian Journal of Civil Engineering, v. 8, no. 3, p. 342-350.

Hem, J.D., 1985, Study and interpretation of the chemical characteristics of natural water: U.S. Geological Survey Water-Supply Paper 2254, 263 p.

Larsen, P.A., 1966, Head losses caused by an ice cover on open channels: Boston Society of Civil Engineers, v. 56, p. $45-67$.
Lavender, S.T., 1984, Winter rating curves and ice volume limited water levels, Proceedings, Workshop on the Hydraulics of River Ice, edited by K.S. Davar and B.C. Burrell, Univ. of New Brunswick, Fredericton, New Brunswick, p. 279-294.

Melcher, N. B., 1988, Computing stream discharge for stream-gaging stations in Iowa during periods of ice effect using index stations and regression equations, Proceedings, 9th International Symposium on Ice, v. 2, International Association for Hydraulic Research, Sapporo, Japan, p. 293-303.

Nedzhikhovskiy, R.A., 1964, Coefficients of roughness of bottom surface on slush-ice cover: Soviet Hydrology, American Geophysical Union, Washington, D.C., p. $127-150$.

Novak, C.E., 1985, WRD data reports preparation guide, 1985 edition, U.S. Geological Survey, 321 p.

Pratte, B.D., 1979, Review of flow resistance of consolidated smooth and rough ice covers, Proceedings, Canadian Hydrology Symposium, Vancouver, British Columbia.

Prior, J.C., 1976, A regional guide to Iowa landforms, Iowa Geological Survey, Educational Series 3, 72 p.

Rantz, S.E. and others, 1982, Measurement and computation of streamflow: volume 2 . computation of discharge: U.S. Geological Survey Water-Supply Paper 2175, $347 \mathrm{p}$.

Rosenberg, H.B. and Pentland R.L., 1983, Accuracy of winter streamflow records: Inland Waters Directorate, Ottawa, Ontario, p. 51-72.

Santeford, H.S. and Alger, G.R., 1984, Predicting flowrates in an ice covered stream, Proceedings, Third International Conference on Cold Regions Engineering, American Society of Civil Engineers, Edmonton, Alberta, p. 1,031-1,043.

1986a, Discharge under an ice cover, Proceedings, Cold Regions Hydrology Symposium, Fairbanks, Alas., edited by D.L. Kane, American Water Resources Association, Bethesda, MD, p. 275-282.

1986b, Stage, discharge, and ice, Proceedings, Sixth International Northern Research Basins Workshop/ Symposium, Michigan Technological University, Houghton, Mich., p. 247-272.

Strilaeff, P.W., 1972, Measurement of discharge under an ice cover, The Role of Snow and Ice in Hydrology, Proceedings of the Banff Symposia, International Association of hydrological Sciences, p. 797-813.

Yapa, P.D., and Shen, H.T., 1986, Unsteady flow simulation for an ice-covered river: American Society of Civil Engineers J. of Hydraulic Engineering, v. 112, no. 11, p. 1,036-1,049. 



\section{APPENDIX}

\section{SURVEY SENT TO U.S. GEOLOGICAL SURVEY OFFICES} AND SELECTED RESULTS 
1. Within each of the following climatic categories, defined by annual runoff, how many gages in your District are in the listed subcategories? These subcategories are defined by the number of days in which backwater from ice affects the normal stage discharge relation. Base the number of days on a typical year. Most Districts will have gages listed in only one or two climatic categories. The sum of the gages listed in the table should equal the total number of gages in your District.

Less than 2 inch of annual runoff (arid)

.2 to 2 inches
of annual
runoff
(semiarid)
2 to 5 inches of annual runoff (subhumid)

Greater than 5 inches of annual runoff

(humid)

Number of gages with:

No ice-affected days

1-5 days of ice effect/year 6-15 days of ice effect/year 16-45 days of ice effect/year 46-90 days of ice effect/year 91-150 days of ice effect/year Greater than 150 days of ice effect/year 
2. Within your District, approximately what percent of the total number of days in which the stage discharge relation is affected by ice is caused by the following conditions? If more than one condition exists simultaneously at a gaging station, consider only the predominant condition. (Your total percent should equal 100 percent.) (Descriptions of these ice conditions can be found in Water-Supply Paper 2175, volume 2, pages 360-363.)

$\begin{array}{ll}\text { frazil ice } & \text { surface ice } \\ \text { anchor ice } & \text { shore ice }\end{array}$

3. Describe briefly the normal methods used by your District for determining discharge during periods of ice effect.

4. Describe any techniques used by your District for determining discharge during ice-affected periods which you think are unusual or have special- merit.

5. Describe any formal projects or backyard efforts which your office has initiated or completed related to evaluating discharge during ice-affected periods. Briefly describe your efforts and conclusions or include a copy of any reports with your response to this questionnaire.

6. The following types of data are commonly used as the basis for determining discharge during periods of backwater from ice. Please mark an " $\mathrm{X}$ " next to the data which are NORMALLY used by your office when computing or estimating stream discharge affected by backwater from ice.

digital stage record discharge measurements recession curves or coefficients discharge ratios ice roughness air temperature snowcover records hydrographic comparison other, please describe stream velocity record correlation with other stations backwater shifts measurements of ice thickness graphic stage record winter precipitation records index stations observer information 
7. How important is the availability of analog stage record for determining discharge during iceaffected periods?
necessary
useful
unnecessary

8. In your District, what is the frequency of discharge measurements made during ice-affected periods?

9. Estimate, for your District, how many total hours of additional time are used to process streamflow data for periods of ice effect. Estimate the additional field time necessary for data collection and office time to compute, check, and review ice-affected periods. "Additional" refers to the extra time necessary to determine streamflow during ice-affected periods compared with computing streamflow by the normal open-water method.

total hours of field time total hours of office time

10. For the gages in your District affected by backwater from ice, how important is the winter record in terms of data use? In other words, to what degree do users of the data consider accuracy of daily values during winter record to be important? Estimate the percent of iceaffected gages in the following categories:

Percent of winter record where accuracy is extremely important important very important not important

11. Data sets are needed to evaluate the available methods for computing discharge during iceaffected periods. Does your District have any stations in which discharge is defined by frequent discharge measurements during the ice-affected period (e.g., measurements at 7-10 day frequency)? Describe stations and data. 
Table A1. - S Summary of responses to survey question 1 . Number of gages with ice-affected days, categorized by inches of runoff, listed by categories of number of days of ice effect per year

\begin{tabular}{|c|c|c|c|c|c|}
\hline & $\begin{array}{c}<.2 \text { in. of } \\
\text { annual } \\
\text { runoff }\end{array}$ & $\begin{array}{c}.2 \text { to } 2 \text { in. } \\
\text { of annual } \\
\text { runoff }\end{array}$ & $\begin{array}{l}2 \text { to } 5 \text { in. } \\
\text { of annual } \\
\text { runoff }\end{array}$ & $\begin{array}{c}>5 \text { in. of } \\
\text { annual } \\
\text { runoff }\end{array}$ & $\begin{array}{l}\text { Total } \\
\text { gages }\end{array}$ \\
\hline \multicolumn{6}{|l|}{ Number of gages with: } \\
\hline No ice-affected days & 77 & 234 & 239 & 2,343 & 2,893 \\
\hline 1-5 days of ice effect/year & 9 & 81 & 42 & 468 & 600 \\
\hline 6-15 days of ice effect/year & 11 & 100 & 64 & 480 & 655 \\
\hline 16-45 days of ice effect/year & 13 & 136 & 72 & 789 & 1,010 \\
\hline $46-90$ days of ice effect/year & 1 & 89 & 131 & 575 & 796 \\
\hline $91-150$ days of ice effect/year & 4 & 194 & 146 & 212 & 556 \\
\hline $\begin{array}{l}\text { More than } 150 \text { days of } \\
\text { ice effect/year }\end{array}$ & 106 & 0 & 15 & 3 & 88 \\
\hline Total & 115 & 849 & 697 & 4,955 & 6,616 \\
\hline
\end{tabular}


Table A2 --- Summary of responses to survey question one. Summary of days of ice-effect for stream-gaging stations, by district

\begin{tabular}{|c|c|c|c|c|}
\hline DISTRICT & $\begin{array}{l}\text { TOTAL NUMBER } \\
\text { STREAM-GAGING } \\
\text { STATIONS }\end{array}$ & $\begin{array}{l}\text { NUMBER OF STATIONS } \\
\text { WITH ICE- } \\
\text { AFFECTED DAYS }\end{array}$ & $\begin{array}{l}\text { TOTAL DAYS OF } \\
\text { ICE EFFECT }\end{array}$ & $\begin{array}{c}\text { PERCENT OF } \\
\text { TOTAL DAYS } \\
\text { WITH ICE EFFECT }\end{array}$ \\
\hline ALABAMA & 78 & 0 & 0 & 0.00 \\
\hline ALASKA & 88 & 86 & 9976 & 31.06 \\
\hline ARKANSAS & 49 & 0 & 0 & 0.00 \\
\hline ARIZONA & 80 & 21 & 343 & 1.17 \\
\hline CALIFORNIA & 500 & 50 & 1140 & 0.62 \\
\hline COLORADO & 295 & 286 & 21063 & 19.56 \\
\hline CONNECTICUT & 48 & 48 & 528 & 3.01 \\
\hline FLORIDA & 285 & 0 & 0 & 0.00 \\
\hline GEORGIA & 108 & 18 & 54 & 0.14 \\
\hline HAWAII & 107 & 0 & 0 & 0.00 \\
\hline IDAHO & 228 & 140 & 5640 & 6.78 \\
\hline ILLINOIS & 135 & 127 & 5786 & 11.74 \\
\hline INDIANA & 167 & 148 & 6413 & 10.52 \\
\hline IOWA & 118 & 114 & 7178 & 16.67 \\
\hline KANSAS & 142 & 128 & 1896 & 3.66 \\
\hline KENTUCKY & 104 & 80 & 1480 & 3.90 \\
\hline LOUISIANA & 70 & 0 & 0 & 0.00 \\
\hline MAINE & 44 & 35 & 2967 & 18.53 \\
\hline MARYLAND, DELAWARE & 100 & 85 & 1315 & 3.60 \\
\hline MASSACHUSETTS & 72 & 40 & 1193 & 4.54 \\
\hline MICHIGAN & 129 & 98 & 5413 & 11.50 \\
\hline MINNESOTA & 83 & 78 & 9743 & 32.16 \\
\hline MISSISSIPPI & 86 & 8 & 24 & 0.08 \\
\hline MISSOURI & 107 & 55 & 1698 & 4.35 \\
\hline MONTANA & 161 & 137 & 9159 & 15.59 \\
\hline NEBRASKA & 144 & 134 & 7309 & 13.91 \\
\hline NEVADA & 96 & 79 & 1589 & 4.53 \\
\hline NEW HAMPSHIRE, VERMON & 70 & 65 & 3005 & 11.76 \\
\hline NEW JERSEY & 100 & 40 & 280 & 0.77 \\
\hline NEW MEXICO & 145 & 116 & 3722 & 7.03 \\
\hline NEW YORK & 184 & 160 & 6408 & 9.54 \\
\hline NORTH CAROLINA & 159 & 30 & 274 & 0.47 \\
\hline NORTH DAKOTA & 73 & 73 & 9210 & 34.57 \\
\hline OHIO & 125 & 100 & 2900 & 6.36 \\
\hline OKLAHOMA & 120 & 85 & 455 & 1.03 \\
\hline OREGON & 259 & 109 & 678 & 0.62 \\
\hline PENNSYLVANIA & 246 & 218 & 6159 & 6.86 \\
\hline PUERTO RICO & 49 & 0 & 0 & 0.00 \\
\hline RHODE ISLAND & 15 & 6 & 139 & 2.54 \\
\hline SOUTH CAROLINA & 120 & 0 & 0 & 0.00 \\
\hline SOUTH DAKOTA & 110 & 95 & 9765 & 24.32 \\
\hline TENNESSEE & 105 & 60 & 180 & 0.47 \\
\hline TEXAS & 386 & 35 & 169 & 0.12 \\
\hline UTAH & 180 & 152 & 8606 & 13.10 \\
\hline VIRGINIA & 82 & 56 & 488 & 1.63 \\
\hline WASHINGTON & 196 & 91 & 1078 & 1.51 \\
\hline WEST VIRGINIA & 70 & 61 & 971 & 3.80 \\
\hline WISCONSIN & 97 & 91 & 8780 & 24.80 \\
\hline \multirow[t]{3}{*}{ WYOMING } & 101 & 96 & 10223 & 27.73 \\
\hline & $======$ & $======$ & $======$ & $======$ \\
\hline & 6,616 & 3,734 & 175,397 & 8.09 \\
\hline
\end{tabular}


Table A3. --- Summary of responses to question two. Number of days of ice effect for each type of ice (Rantz and others, 1982), by district

\begin{tabular}{|c|c|c|c|c|}
\hline DISTRICT & $\begin{array}{l}\text { DAYS OF } \\
\text { FRAZIL }\end{array}$ & $\begin{array}{l}\text { DAYS OF } \\
\text { ANCHOR }\end{array}$ & $\begin{array}{l}\text { DAYS OF } \\
\text { SURFACE }\end{array}$ & $\begin{array}{c}\text { DAYS OF } \\
\text { SHORE }\end{array}$ \\
\hline ALABAMA & 0 & 0 & 0 & 0 \\
\hline ALASKA & 100 & 199 & 9,278 & 399 \\
\hline ARKANSAS & 0 & 0 & 0 & 0 \\
\hline ARIZONA & 86 & 17 & 171 & 69 \\
\hline CALIFORNIA & 0 & 0 & 1,140 & 0 \\
\hline COLORADO & 1,053 & 5,266 & 8,425 & 6,319 \\
\hline CONNECTICUT & 0 & 53 & 396 & 79 \\
\hline FLORIDA & 0 & 0 & 0 & 0 \\
\hline GEORGIA & 0 & 49 & 5 & 0 \\
\hline HAWAII & 0 & 0 & 0 & 0 \\
\hline IDAHO & 1,128 & 1,692 & 2,256 & 564 \\
\hline ILLINOIS & 116 & 174 & 3,934 & 1,562 \\
\hline 1NDIANA & 0 & 834 & 4,874 & 705 \\
\hline IOWA & 215 & 359 & 5,814 & 790 \\
\hline KANSAS & 0 & 285 & 1,326 & 285 \\
\hline KENTUCKY & 74 & 1,184 & 74 & 148 \\
\hline LOUISIANA & 0 & 0 & 0 & 0 \\
\hline MAINE & 0 & 148 & 2,225 & 594 \\
\hline MARYLAND, DELAWARE & 66 & 263 & 723 & 263 \\
\hline MASSACHUSETTS & 0 & 191 & 787 & 215 \\
\hline MICHIGAN & 0 & 271 & 4,601 & 541 \\
\hline MINNESOTA & 487 & 487 & 8,282 & 487 \\
\hline MISSISSIPPI & 0 & 0 & 1 & 23 \\
\hline MISSOURI & 255 & 255 & 1,018 & 170 \\
\hline MONTANA & 92 & 275 & 8,243 & 549 \\
\hline NEBRASKA & 731 & 0 & 5,847 & 731 \\
\hline NEVADA & 0 & 0 & 1,192 & 397 \\
\hline NEW HAMPSHIRE，VERMONT & 150 & 300 & 2,104 & 451 \\
\hline NEW JERSEY & 0 & 0 & 140 & 140 \\
\hline NEW MEXICO & 0 & 372 & 2,233 & 1,117 \\
\hline NEW YORK & 192 & 1,923 & 3,204 & 1,089 \\
\hline NORTH CAROLINA & 0 & 219 & 0 & 55 \\
\hline NORTH DAKOTA & 0 & 0 & 9,210 & 0 \\
\hline $\mathrm{OHIO}$ & 290 & 580 & 580 & 1,450 \\
\hline OKLAHOMA & 0 & 5 & 364 & 86 \\
\hline OREGON & 13 & 88 & 102 & 475 \\
\hline PENNSYLVANIA & 123 & 1,047 & 4,003 & 986 \\
\hline PUERTO RICO & 0 & 0 & 0 & 0 \\
\hline RHODE ISLAND & 0 & 22 & 117 & 0 \\
\hline SOUTH CAROLINA & 0 & 0 & 0 & 0 \\
\hline SOUTH DAKO'TA & 0 & 488 & 8,789 & 488 \\
\hline TENNESSEE & 0 & 72 & 0 & 108 \\
\hline TEXAS & 25 & 25 & 51 & 68 \\
\hline UTAH & 430 & 861 & 5,594 & 1,721 \\
\hline VIRGINIA & 15 & 88 & 117 & 268 \\
\hline WASHINGTON & 21 & 140 & 162 & 755 \\
\hline WEST VIRGINIA & 126 & 0 & 0 & 845 \\
\hline WISCONSIN & 351 & 175 & 6,322 & 1,932 \\
\hline \multirow{4}{*}{ WYOMING } & 1,022 & 1,533 & 5,112 & 2,556 \\
\hline & $========$ & $========$ & $==== \pm===$ & $=======$ \\
\hline & 7,161 & 19,940 & 118,816 & 29,480 \\
\hline & $4 \%$ & $11 \%$ & $68 \%$ & $17 \%$ \\
\hline
\end{tabular}


Table A4 --- Summary of responses to survey question six. Data used for estimating streamflow during ice-affected periods, by district

ALABAMA

ALASKA

ARKANSAS

ARIZONA

CALIFORNIA

COLORADO

CONNECTICUT

FLORIDA

GEORGIA

HAWAII

IDAHO

ILLINOIS

INDIANA

IOWA

KANSAS

KENTUCKY

LOUISIANA

MAINE

MARYLAND, DELAWARE

MASSACHUSETTS

MICHIGAN

MINNESOTA

MISSISSIPPI

MISSOURI

MONTANA

NEBRASKA

NEVADA

NEW HAMPSHIRE, VERMONT

NEW JERSEY

NEW MEXICO

NEW YORK

NORTH CAROLINA

NORTH DAKOTA

$\mathrm{OHIO}$

OKLAHOMA

OREGON

PENNSYLVANIA

PUERTO RICO

RHODE ISLAND

SOUTH CAROLINA

SOUTH DAKOTA

TENNESSEE

TEXAS

UTAH

VIRGINIA

WASHINGTON

WEST VIRGINIA

WISCONSIN

WYOMING

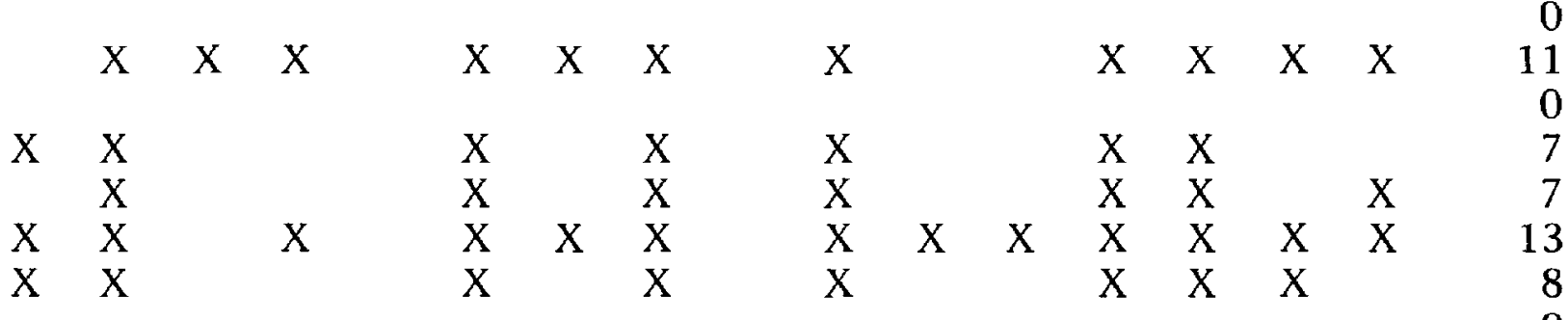

0

8

0

$\begin{array}{llllllllllllll}X & X & X & X & & X & X & & X & X & X & X & 10 \\ X & X & X & X & X & X & X & X & X & X & X & X & 13\end{array}$

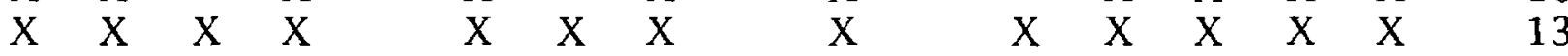

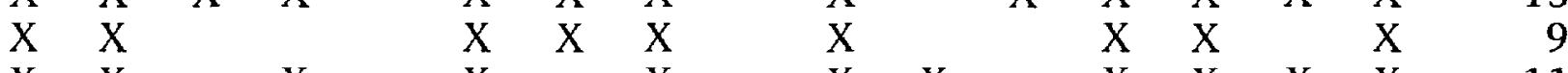

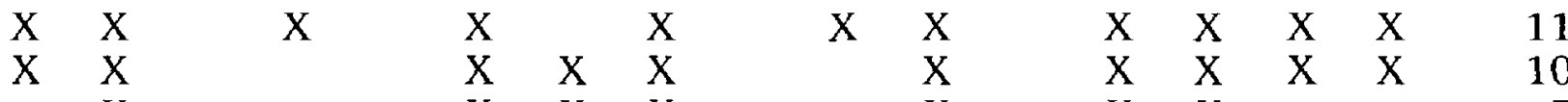

$\mathrm{X} X \mathrm{X} \quad \mathrm{X} \quad \mathrm{X} \quad \mathrm{X} \quad \mathrm{X}$

$\begin{array}{llllllllll}X & X & X & & X & X & & & X & \\ X & X & X & X & X & X & X & X & X & X\end{array}$

$\begin{array}{lllllllll}X & X & X & X & X & X & X & X & X \\ X & X & X & X & X & X & X & X\end{array}$

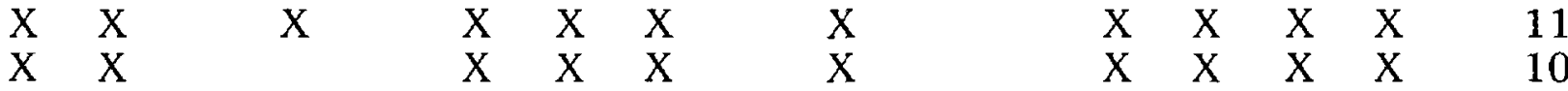

$\begin{array}{llllllllll}X & X & X & X & X & X & X & X & X & \end{array}$

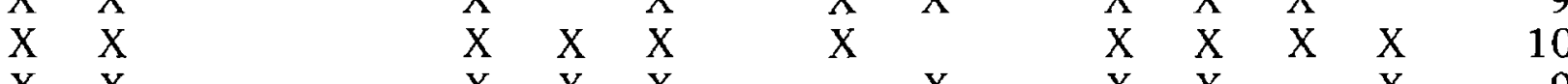

$\begin{array}{lllllllllll}X & X & X & X & X & & X & X & X & X & 9 \\ X & X & X & & X & & & & X & & 5 \\ X & X & X & & X & X & & & X & X & X\end{array}$

$X \quad X$

$X \quad X$

$X \quad X$

$X \quad X \quad X \quad X$

$\begin{array}{llll} & X & & \\ X & X & X & X \\ X & X & X & X\end{array}$

$X \quad X$

$X \quad X$

$\mathrm{X} \quad \mathrm{X} \quad \mathrm{X}$

$\mathrm{X} \quad \mathrm{X}$

$\mathrm{X}$

$X$

$\mathrm{X}$
$\mathrm{X}$

$\mathrm{X}$

$\mathrm{X}$

X

$\begin{array}{llll}X & & \\ X & X & X \\ X & X & X\end{array}$

$\begin{array}{lll}X & X & 8 \\ X & & 8\end{array}$

X X

$\mathrm{X}$

$\mathrm{X}$

$\begin{array}{lllll}X & X & X & X & 13\end{array}$

$X \quad X$

$\begin{array}{ll}X & X \\ X & X\end{array}$

$\begin{array}{lll}X & X & X\end{array}$

$X \quad X$

$X \quad X$

$\begin{array}{lllll}X & X & X & & X \\ X & X & X & \\ & X & X & \\ X & X & X & X & X \\ X & X & X & X & X\end{array}$

$X \quad X \quad X$

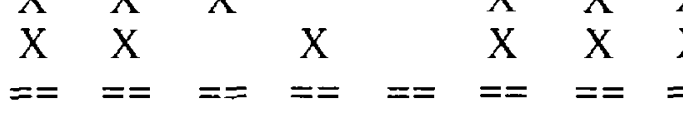

$\begin{array}{lllllll}35 & 40 & 8 & 12 & 0 & 38 & 18\end{array}$
DS digital stage record

DM discharge measurements

RC recession curves or coefficients

DR discharge ratios

IR ice roughness

AT air temperature

SR snowcover records

$\mathrm{HC}$ hydrographic comparison
SV stream velocity record

CS correlation w/other stations

BS backwater shifts

MT measurements of ice thickness

GS graphic stage record

WP winter precipitation records

IS index stations

Ol observer information 
Table A5 --- Summary of responses to survey question seven. Importance of analog stage record for completing ice-affected streamflow record, by district

\begin{tabular}{|c|c|c|c|}
\hline DISTRICT & NECESSARY & USEFUL & UNNECESSARY \\
\hline \multicolumn{4}{|l|}{ ALABAMA } \\
\hline ALASKA & $\mathrm{X}$ & & \\
\hline $\begin{array}{l}\text { ARKANSAS } \\
\text { ARIZONA }\end{array}$ & & & \\
\hline ARIZONA & & $\begin{array}{l}\mathrm{X} \\
\mathrm{y}\end{array}$ & \\
\hline $\begin{array}{l}\text { CALIFORNIA } \\
\text { COLORADO }\end{array}$ & & & \\
\hline COLORADO & & $\mathrm{x}$ & \\
\hline \multirow{2}{*}{\multicolumn{4}{|c|}{ FLORIDA }} \\
\hline & & & \\
\hline \multicolumn{4}{|l|}{ GEORGIA } \\
\hline IDAHO & $\mathrm{X}$ & & \\
\hline ILLINOIS & & $\mathrm{X}$ & \\
\hline INDIANA & $\mathrm{X}$ & & \\
\hline IOWA & $\mathrm{X}$ & & \\
\hline KANSAS & $\mathrm{X}$ & & \\
\hline KENTUCKY & $\mathrm{x}$ & & \\
\hline \multicolumn{4}{|l|}{ LOUISIANA } \\
\hline MAINE & & & $\mathrm{X}$ \\
\hline MARYLAND， DELAWARE & & $\mathrm{X}$ & \\
\hline MASSACHUSETTS & $\mathrm{X}$ & & \\
\hline MICHIGAN & $\mathrm{X}$ & & \\
\hline MINNESOTA & $\mathrm{X}$ & $\mathrm{X}$ & \\
\hline \multicolumn{4}{|l|}{ MISSISSIPPI } \\
\hline MISSOURI & & $\mathrm{x}$ & \\
\hline MONTANA & & $\mathrm{X}$ & \\
\hline NEBRASKA & & $\mathrm{X}$ & \\
\hline \multirow{2}{*}{\multicolumn{4}{|c|}{ NEW HAMPSHIRE, VERMONT }} \\
\hline & & & \\
\hline NEW JERSEY & & $\mathrm{X}$ & \\
\hline NEW MEXICO & & $\mathrm{x}$ & \\
\hline NEW YORK & & $\mathrm{X}$ & \\
\hline NORTH CAROLINA & $\mathrm{X}$ & & \\
\hline NORTH DAKOTA & & $\mathrm{X}$ & \\
\hline OHIO & & $\mathrm{X}$ & \\
\hline OKLAHOMA & & $\mathrm{x}$ & \\
\hline OREGON & & $\mathrm{X}$ & \\
\hline PENNSYLVANIA & $\mathrm{X}$ & $\mathrm{X}$ & \\
\hline \multicolumn{4}{|l|}{ PUERTO RICO } \\
\hline RHODE ISLAND & $\mathrm{X}$ & & \\
\hline \multicolumn{4}{|l|}{ SOUTH CAROLINA } \\
\hline SOUTH DAKOTA & & $\mathrm{X}$ & \\
\hline TENNESSEE & & $\mathrm{x}$ & \\
\hline TEXAS & & $\mathrm{X}$ & \\
\hline UTAH & & $\mathrm{X}$ & \\
\hline VIRGINIA & & $\mathrm{X}$ & \\
\hline WASHINGTON & & $\mathrm{X}$ & \\
\hline WEST VIRGINIA & & $\mathrm{X}$ & \\
\hline WISCONSIN & & $\mathrm{X}$ & \\
\hline \multirow[t]{3}{*}{ WYOMING } & $\mathrm{X}$ & & \\
\hline & $== \pm==-$ & $======$ & $======$ \\
\hline & 15 & 26 & 1 \\
\hline
\end{tabular}


Table A6 --- Summary of responses to survey question nine. Additional office and field hours used to compute streamflow during ice-affected periods, by district

DISTRICT
FIELD OFFICE

HOURS HOURS
HOURS USED PER ICE DAY

(FIELD + OFFICE HOURS TOTAL DAYS OF ICE)

ALABAMA
ALASKA
ARKANSAS
ARIZONA
CALIFORNIA
COLORADO
CONNECTICUT
FLORIDA
GEORGIA
HAWAII
IDAHO
ILLINOIS
INDIANA
IOWA
KANSAS
KENTUCKY
LOUISIANA
MAINE
MARYLAND, DELAWARE
MASSACHUSETTS
MICHIGAN
MINNESOTA
MISSISSIPPI
MISSOURI
MONTANA
NEBRASKA
NEVADA
NEW HAMPSHIRE, VERMONT
NEW JERSEY
NEW MEXICO
NEW YORK
NORTH CAROLINA
NORTH DAKOTA
OHIO
OKLAHOMA
OREGON
PENNSYLVANIA
PUERTO RICO
RHODE ISLAND
SOUTH CAROLINA
SOUTH DAKOTA
TENNESSEE
TEXAS
UTAH
VIRGINIA
WASHINGTON
WEST VIRGINIA
WISCONSIN
WYOMING
WYOM

\begin{tabular}{|c|c|c|}
\hline 0 & 0 & - \\
\hline 300 & 350 & 0.07 \\
\hline 0 & 0 & - \\
\hline 220 & 450 & 1.95 \\
\hline 200 & 200 & 0.35 \\
\hline 400 & 450 & 0.04 \\
\hline 96 & 48 & 0.27 \\
\hline 0 & 0 & - \\
\hline 0 & 0 & 0.00 \\
\hline 0 & 0 & - \\
\hline 1,080 & 960 & 0.36 \\
\hline 280 & 285 & 0.10 \\
\hline 270 & 540 & 0.13 \\
\hline 488 & 635 & 0.16 \\
\hline 128 & 192 & 0.17 \\
\hline 0 & 100 & 0.07 \\
\hline 0 & 0 & - \\
\hline 140 & 350 & 0.17 \\
\hline 80 & 80 & 0.12 \\
\hline 186 & 568 & 0.63 \\
\hline 200 & 500 & 0.13 \\
\hline 540 & 2,000 & 0.26 \\
\hline 0 & 0 & 0.00 \\
\hline 200 & 100 & 0.18 \\
\hline 950 & 3,900 & 0.53 \\
\hline 1,352 & 610 & 0.27 \\
\hline 300 & 250 & 0.35 \\
\hline 300 & 400 & 0.23 \\
\hline 23 & 95 & 0.42 \\
\hline 100 & 400 & 0.13 \\
\hline 990 & 1,420 & 0.38 \\
\hline 0 & 0 & 0.00 \\
\hline 800 & 400 & 0.13 \\
\hline 1,000 & 1,500 & 0.86 \\
\hline 20 & 45 & 0.14 \\
\hline 285 & 512 & 0.76 \\
\hline 650 & 600 & 0.20 \\
\hline 0 & 0 & - \\
\hline 16 & 56 & 0.52 \\
\hline 0 & 0 & \\
\hline 160 & 340 & 0.05 \\
\hline 200 & 250 & 2.50 \\
\hline 10 & 80 & 0.53 \\
\hline 200 & 100 & 0.03 \\
\hline 10 & 56 & 0.14 \\
\hline 215 & 388 & 0.56 \\
\hline 240 & 120 & 0.37 \\
\hline 740 & 670 & 0.16 \\
\hline 900 & 900 & 0.18 \\
\hline 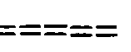 & & \\
\hline 4,269 & 20,900 & 0.30 \\
\hline
\end{tabular}


Table A7 -.- Summary of responses to survey question ten. Relative importance of stream-gaging station data, by district

TOTAL

DISTRICT

EXTREMELY

VERY

NOT

ALABAMA

ALASKA

ARKANSAS

ARIZONA

CALIFORNIA

COLORADO

CONNECTICUT

FLORIDA

GEORGIA

HAWAII

IDAHO

ILLINOIS

INDIANA

IOWA

KANSAS

KENTUCKY

LOUISIANA

MAINE

MARYLAND, DELAWARE IMPORTANT IMPORTANT IMPORTANT IMPORTANT ICE-AFFECT

MASSACHUSETTS

MICHIGAN

MINNESOTA

MISSISSIPPI

MISSOURI

MONTANA

NEBRASKA

NEVADA

NEW HAMPSHIRE, VERMONT

NEW JERSEY

NEW MEXICO

NEW YORK

NORTH CAROLINA

NORTH DAKOTA

$\mathrm{OHIO}$

OKLAHOMA

OREGON

PENNSYLVANIA

PUERTO RICO

RHODE ISLAND

SOUTH CAROLINA

SOUTH DAKOTA

TENNESSEE

TEXAS

UTAH

VIRGINIA

WASHINGTON

WEST VIRGINIA

WISCONSIN

WYOMING

\begin{tabular}{|c|c|c|c|c|}
\hline 0 & 0 & 0 & 0 & 0 \\
\hline 3 & 7 & 62 & 14 & 86 \\
\hline 0 & 0 & 0 & 0 & 0 \\
\hline 8 & 11 & 2 & 0 & 21 \\
\hline 0 & 0 & 25 & 25 & 50 \\
\hline 14 & 72 & 157 & 43 & 286 \\
\hline 0 & 0 & 48 & 0 & 48 \\
\hline 0 & 0 & 0 & 0 & 0 \\
\hline 0 & 0 & 0 & 18 & 18 \\
\hline 0 & 0 & 0 & 0 & 0 \\
\hline 14 & 28 & 98 & 0 & 140 \\
\hline 0 & 4 & 76 & 47 & 127 \\
\hline 7 & 22 & 119 & 0 & 148 \\
\hline 5 & 45 & 10 & 54 & 114 \\
\hline 0 & 0 & 128 & 0 & 128 \\
\hline 0 & 0 & 80 & 0 & 80 \\
\hline 0 & 0 & 0 & 0 & 0 \\
\hline 4 & 24 & 7 & 0 & 35 \\
\hline 0 & 0 & 77 & 8 & 85 \\
\hline 0 & 20 & 20 & 0 & 40 \\
\hline 5 & 10 & 83 & 0 & 98 \\
\hline 9 & 16 & 43 & 10 & 78 \\
\hline 0 & 0 & 0 & 8 & 8 \\
\hline 0 & 0 & 55 & 0 & 55 \\
\hline 0 & 0 & 82 & 55 & 137 \\
\hline 0 & 0 & 134 & 0 & 134 \\
\hline 0 & 0 & 79 & 0 & 79 \\
\hline 6 & 52 & 7 & 0 & 65 \\
\hline 0 & 4 & 12 & 24 & 40 \\
\hline 0 & 0 & 46 & 70 & 116 \\
\hline 10 & 48 & 56 & 46 & 160 \\
\hline 0 & 0 & 0 & 30 & 30 \\
\hline 0 & 73 & 0 & 0 & 73 \\
\hline 0 & 0 & 100 & 0 & 100 \\
\hline 0 & 0 & 85 & 0 & 85 \\
\hline 6 & 0 & 76 & 27 & 109 \\
\hline 6 & 22 & 72 & 118 & 218 \\
\hline 0 & 0 & 0 & 0 & 0 \\
\hline 0 & 3 & 3 & 0 & 6 \\
\hline 0 & 0 & 0 & 0 & 0 \\
\hline 57 & 10 & 9 & 19 & 95 \\
\hline 0 & 0 & 60 & 0 & 60 \\
\hline 0 & 0 & 35 & 0 & 35 \\
\hline 0 & 8 & 137 & 7 & 152 \\
\hline 0 & 0 & 56 & 0 & 56 \\
\hline 4 & 0 & 64 & 23 & 91 \\
\hline 0 & 0 & 0 & 61 & 61 \\
\hline 0 & 2 & 86 & 3 & 91 \\
\hline$=9$ & 29 & 48 & 10 & 96 \\
\hline 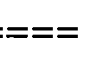 & $=====$ & $====$ & $=====$ & $====x$ \\
\hline 167 & 510 & 2,337 & 720 & 3,734 \\
\hline $4 \%$ & $14 \%$ & $63 \%$ & $19 \%$ & \\
\hline
\end{tabular}






\section{$\therefore \quad-$}

